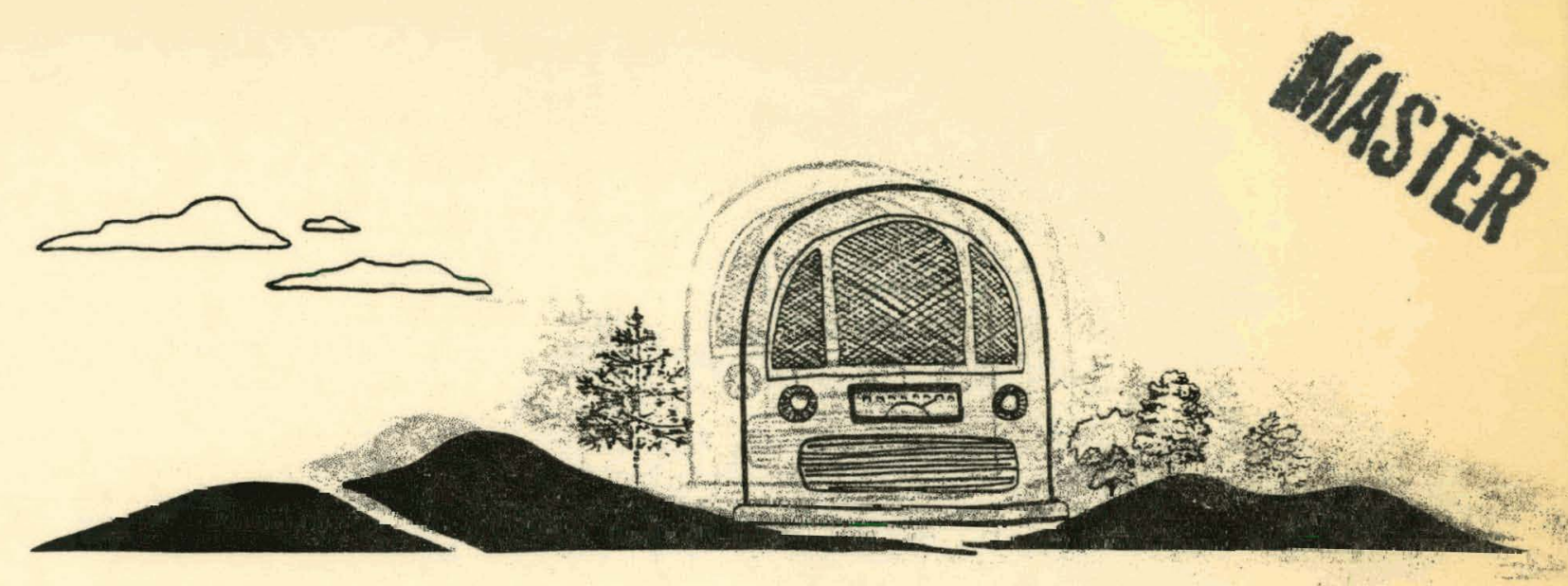

\title{
The Chautauqua Notebook: appropriate technology on radio
}

$$
\text { FG03-801R } 11128
$$

bỹ:

bobbi renz 


\section{DISCLAIMER}

This report was prepared as an account of work sponsored by an agency of the United States Government. Neither the United States Government nor any agency Thereof, nor any of their employees, makes any warranty, express or implied, or assumes any legal liability or responsibility for the accuracy, completeness, or usefulness of any information, apparatus, product, or process disclosed, or represents that its use would not infringe privately owned rights. Reference herein to any specific commercial product, process, or service by trade name, trademark, manufacturer, or otherwise does not necessarily constitute or imply its endorsement, recommendation, or favoring by the United States Government or any agency thereof. The views and opinions of authors expressed herein do not necessarily state or reflect those of the United States Government or any agency thereof. 


\section{DISCLAIMER}

Portions of this document may be illegible in electronic image products. Images are produced from the best available original document. 


\section{The following pages are an exact representation of what is in the original document folder.}




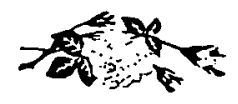

Many thanks to the Director of the office of Consumer Affairs of the U.S. Department of Energy, Tina Hobson, whose vision of energy conservation is broad enough to include use of the bioadeast media as an appropriate tool not only for disseminating information on appropriate technology, but for pooling the knowledge of the nation!" most valuable resource-its people.
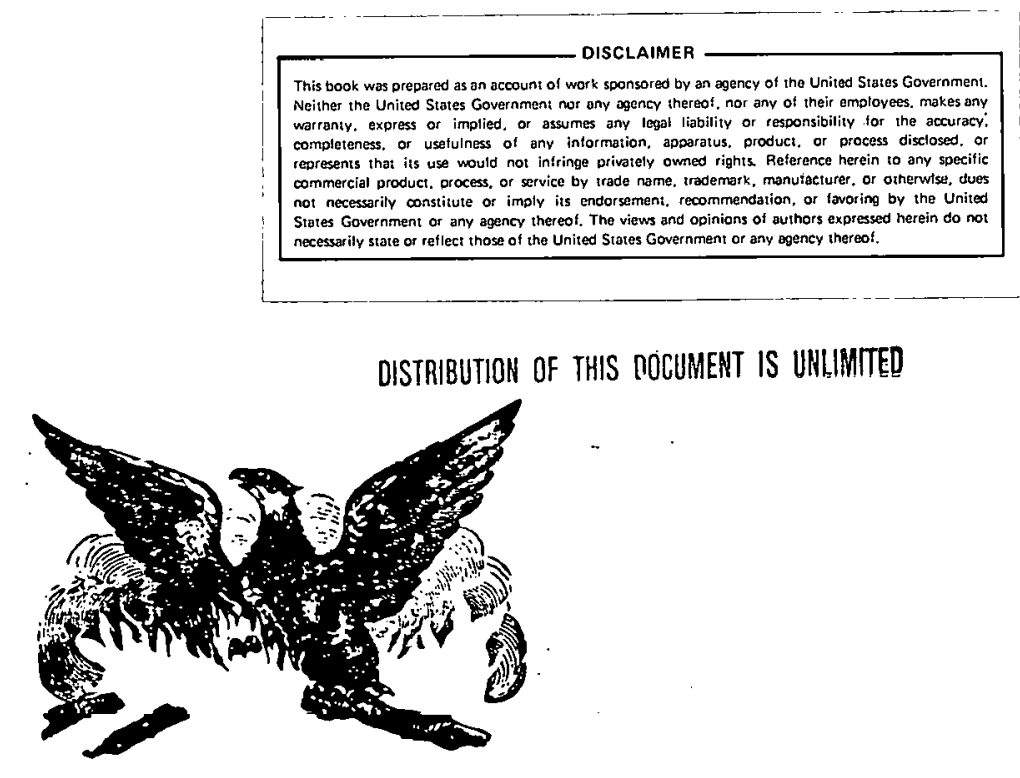

As part of a larger project, this Notebook was prepared with a portion of the funds provided by DOE Grant No. FG 0380IR-11128 appropriated by the office of Consumer Affairs; U.S. Department of Energy. The views and opinions expressed herein are not necessarily thoge of the U.E. Covernment nor. the U.S. Department of Energy.

This Notebook was written and prepared by the Chautaugua Institute for Self-Reliance which is solely responsible: for its contents. 


\section{TABLE OF CONTENTS}

FOREWORD

A. APPROPRIATE TECHNOLOGY

B. THE CHAUTAUQUA CONCEPT

C. TOPICS

D . RESEARCH

E. GUESTS

F. INTERVIEWING TIPS

G. LISTENERS

H. PROGRAM FEATURES

I. FINDING HELP

J. PROMOTION \& PUBLICITY

K. TECHNICAL/ENGINEERING

L . BIIDGET

M. FUNDING

N. STATION POLICIES

AFTERWORD

APPENDIX

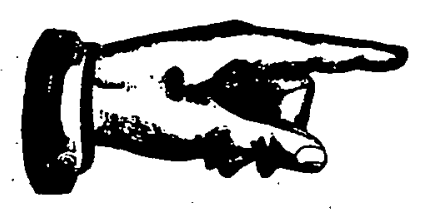




\section{FOREWORD}

During the past three years. I have worked to establish a daily call-in program on Public Radio Station WOUB-FM in Athens, Ohio. The program, Chautauqua, is an informal "information exchange" whereby 1 isteners, guests, and $I$, as the show's host, share practical and do-it-yourself ideas on a wide range of appropriate technology and self-reliance topics.

Because listening to the radio is, for millions, a common everyday experience, Chautauqua has proven the call-in format to be an effective and efficient way to disseminate information on conservation, renewable energy, appropriate technology, and self-reliance.

The level of listener interest and participation in Chautauqua is impressive; people have come to rely upon the program for credible information which is in-tune with their lives and their needs. The mood of the show is lively and dow-to-earth and encourages all sorts and ages of people to share what they have experienced with others.

After seeing and hearing the success of this show, I have come to believe that using a call-in radio program like Chautauqua as a vehicle for information-exchange is an important option for change whose potential has not yet been realized. It's an important piece of the same puzzle into which we already fit. appropriate technology books, journals, magazines, pamphlets, newspapers, and hands-on workshops. 
The writing of this notebook is an effort to share my experience in establishing and maintaining a regional call-in information-exchange on appropriate technology and self-reliance.

I'm hopeful that as the idea and enthusiasm for this show spreads, other call-in shows like Chautauqua might develop all across the United States, making use of yet another important tool for solving some of our most pressing contemporary energy problems.

\section{BOBBI RENZ \\ Producer/Host}

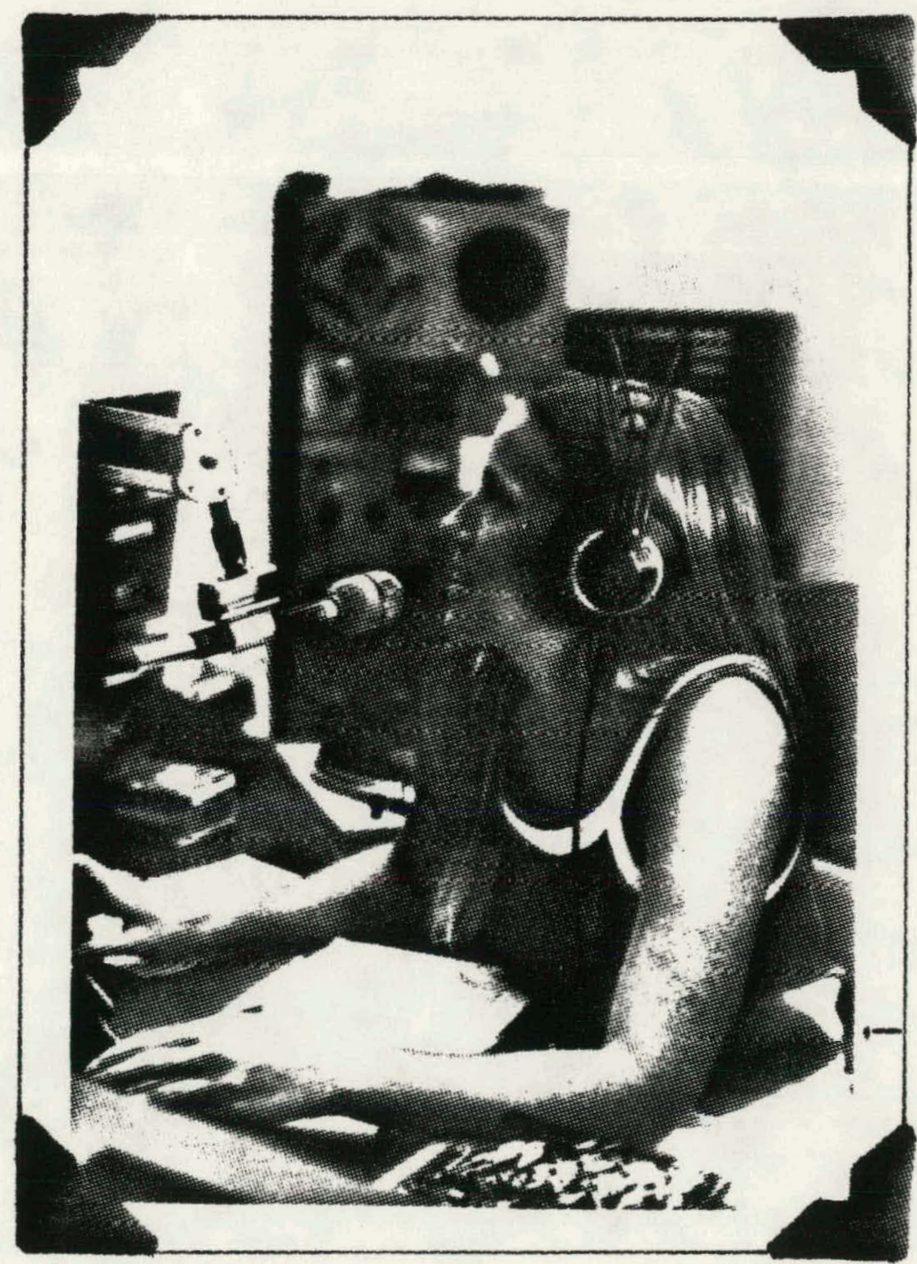




\section{AppropriateTechnology}


For years now, we in the United States have been chasing after the lifestyle and belief that "bigger is better." The complications and ramifications of this pursuit are many and far-reaching.

We have come to rely heavily upon "high technology" to take care of many of our needs. But because the understanding and control of this high technology rests with just a few individuals, it leaves the rest of us highly dependent, in the dark, and out of control. This may well be the first time in history that the majority of the people in a society have lost the basic knowledge and skills necessary to provide for their own individual needs.

There is a growing disillusionment with this state of affairs; a growing belief that technology should be more appropriate to our needs while giving greater respect to our resources at hand.

The term "appropriate technology" advocates a greater number of small, decentralized technologies to meet our needs for food production and preservation, energy, shelter, etc. Appropriate technology makes use of renewable local resources, relies heavily upon human labor and skill, and holds high the commitment to conserve and use our remaining resuurces efficiently.

Appropriate technology makes greater use of decentralized technologies and systems which are simple to install, operate, and maintain. This leaves the responsibility for their operation and maintenance with individuals and/or communities. 
Because these systems are decentralized, they can be tailor-made to suit the needs of the people in any given region while paying close attention to the local environment, resources, materials, job-needs, and climate in that area.

Along with a variety of new technologies, many of the concepts and systems offered under the label of appropriate technology are actually age-old methods of doing things which have simply been adapted to contemporary times. Appropriate technology, itself, doesn't mean going back to "horse and buggy" days. It does, however, require that we undertake astask of self-examination in order to rediscover our basic needs and that we inventory our limited resources in order to develop systems which can link the two in ways that are appropriate and environmentally sound.

There are thousands of people in this country who are completely unaware that they are using what we call "appropriate technologies" in their everyday lives. These people have simply been using the resources at hand to get something accomplished, perhaps because those resources are the only ones lhey can afford, or because they are the only ones available, or perhaps because of values which dictate a job to be done in a certain way.

Add to that the recent innovations in the field of renewable energy, modern adaptations of old ideas, and the new enthusiasm for doing-for-oneself, and there's a vast potential for more appropriate technologies which are compatible not only with our economic needs, but with our environmental, social, and human needs as well. 
Somewhere in this technological evolution there is a role for the broadcast media to play in communicating all the things that groups and individuals are doing to develop the field of appropriate technology. In fact, there is an unrealized potential for turning broadcast technology, itself, into an appropriate technological tool which can be used to help us reach an appropriate and sustainable future.

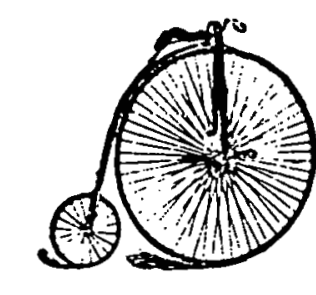




\section{The Chautauqua Concept}


In retrospect, the development of Chautauqua seemed to spring almost from nowhere, guiding me in its course, taking me along on its journey. Realistically, I know this isn't so. I can vividly recall the long hours of hard work that I put in on the development of the show. I remember all the hurdles which, at times, seemed insurpassable and also the successes which charged me with excitement.

Today, I describe Chautauqua as a call-in radio show on appropriate technology and self-reliance, and whiłe that is, in fact, what the show has always been about, I didn't categorize it in this way in its early days. Instead, I envisioned Chautauqua to be a down-to-earth radio call-in show discussing woodstoves, solar greenhouses, growing and preserving food, and lots of other do-it-yourself ideas.

The name for the show was suggested by a friend's grandmother who, in hearing a description of the proposed program, commented that it reminded her of the tent-Chautauquas which traveled through the region early in the century. Many older people in this rural area remember these traveling Chautauquas as a social event in which people from around the region gathered to learn new skills, to share experiences, and to exchange information. Ironically, when radio and television came into existence, the traveling Chautauquas were phased out. Now, years later, I have witnessed how effective radio can be in allowing its listeners to share information with one another without leaving their homes. Hence, the name "Chautauqua." 
In November of 1977 , I volunteered to host Chautauqua. The managers at Public Station WOUB-FM agreed (with much persuasion and enthusiasm exerted on my part) to broadcast the show live every weekday morning from 9:05 (right after the network news) to 9:30. My role was defined as the producer/host of the show and, as such, I felt I must have some knowledge of the topics so that I could ask appropriate questions and, in general, direct the show.

Although I had a great interest and enthusiasm in alternative energy, conservation, growing and preserving food and the like, I had very little real knowledge on the specifics of any of these things. So I began to research each program topic in magazines, books, and-perhaps most importantly-by talking to as many people as possible. What I lacked in specific knowledge, I made up for in curiosity and enthusiasm.

But my role in the show was just one of the many to be played. From the bcginning, I felt that the listeners and guests. . .each knowledgeable and informed in different subjects. . .would be the major resource, the major contributors of information which would give the show its substance. I had a feeling that if we could just pool our varied information and experience, that we could tap a wealth of knowledge on most any topic.

Now, three years and nearly 750 Chautauqua programs later, I believe, without a doubt, that I could get on the radio and request just abnut any sort of appropriate technology information and somewhere out there a person would have the answer and, if encouraged, would call in to share that information with the rest of us. From past experiences, I know that I can ask for information on how to pump water a hundred feet to a house without electricity, for example, 
and get perhaps three possible options for doing so-each described in detail by a knowledgeable listener.

Needless to say, the idea of a cal1-in information-exchange on appropriate technology and self-sufficiency has been extremely successful. After being on the air a little over a year, listener feedback indicated that more air time was needed each day. As a result, Chautauqua was expanded to 55 minutes and is now broadcast each weekday morning from 9:05 to 10:00 over Public Station WOUB-FM.

In the course of Chautauqua's existence, people from our 32-county 1 istening area of Southeastern Ohio and West Virginia have exchanged enough information to fill volumes of books. Listeners have written in with descriptions of the many projects they have attempted in conservation and appropriate technology and they often credit Chautauqua with playing a role in the development of those projects.

I feel that one of the main reasons the program has become a success is because, unlike most cal1-in shows which often sensationalize topics and intimidate or antagonize callers, Chautauqua's down-to-earth informational and non-antagonistic approach encourages the participation of even the least aggressive of people who have information to share.

I should take this opportunity to say that, personally, I can listen to a more typical cal1-in talk show for only a short time because by and large these shows are just a sounding board for complaints and heated arguments which often lead nowhere. As a result, they leave me with a very negative feeling. 
From the beginning, my idea was that Chautauqua would take up where the stereotypical call-in show leaves off. While the other shows might spend three days encouraging listeners to call in about the recent increase in electri,c bills, Chautauqua will spend three days exchanging practical ways to cut back on non-renewable energy consumption; weatherization; alternative renewable energy sources; etc. When given encouragement, the people of this country are incredibly innovative and independent and they are more than willing to share their innovations with others so that they, too, might benefit.

Not only does Chautauqua provide for the exchange of information, it makes it possible for people to give public recognition to the individuals in this region who are actually making a go of self-reliance-who are actually applying appropriate techology to their daily lives. This much-deserved recognition for individuals not only illustrates the practicality of small-scale technologies, it also offers encouragement and motivation to others who may be considering doing more for themselves.

To the many inexperienced people who are just beginning to use wood cookstoves, the years of experience passed on over the radio by other 1 isteners is valuable information. And listeners are quick to express their appreciation: "I was so glad to hear from the gentleman from Lancaster, Ohio, who described how to control the temperature on a wood cookstove because I couldn't find any book to help me and I just couldn't catch-on to the trick of it myself."

Radio is not only a mass medium, it is a very personal medium and it can go a long way in promoting the general philosophy of appropriate technology. 
A call-in show seems an obvious natural for both pooling and disseminating specific how-to information on a variety of topics. Millions of people have radios in their homes, cars, and offices, and most of those same people have access to a telephone. These two technologies (radio and telephone) are a familiar part of our lives, and they make it possible for people of all ages, professions, and backgrounds to get together to share ideas and information without leaving home!

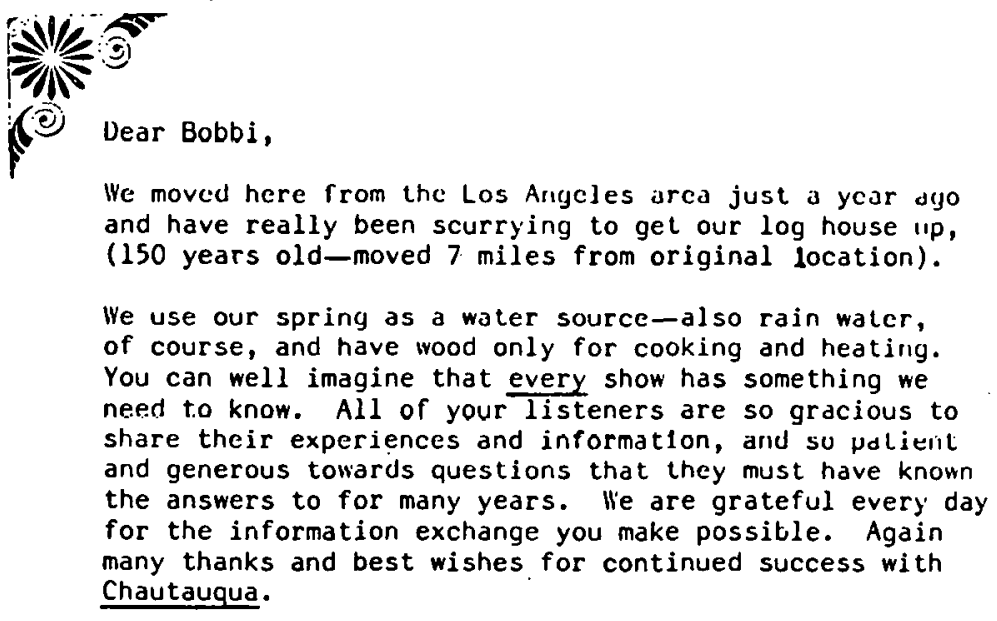

J.5.

Ravensivood, IV: Va,

Sept. 9,1980

Dear Bobbi,

First. let me say that your show is my favorite locally produced program. It disseminates good information, but what makes it unique is the way it draws out the wisdom and knnwledge. of the audience. I am sure you agree this knowledge is considerable. Too of ten, consumer oriented programs seem to assume that the audience is incompetent or in dire need of the information given to survive. Your show is a positive and much needed service.

I find it especially heartening to hear from people who are actually living the way $I$ am trying to learn how to live. That is, using less energy, and yet doing so in a creative, foyful way rather than in the spirit of deprivation...

C.K.

Athens, $\mathrm{OH}$

January 4, 1979 


\section{Topics}




\section{TOPICS}

Several years ago, someone asked, "Don't you think you're going to run out of topics to discuss pretty soon?"

I was quick to reply, "I can't imagine it." Even though

I have hosted about 750 live Chautauqua shows during these first three years, we've never run out of things to discuss.

There are hundreds, if not thousands, of appropriate technology topics to be discussed in each part of the world-and we have the opportunity to get specific on this show. For example, when you're sharing how-to information on building a solar food dryer, you need to get down to the nuts and bolts of how to do it: what materials do you use? What size works best? How much does it cost? Etc.

Instead of skimming the surface by doing just a 5-minute interview with someone who built a solar dryer, we'll take as much time as needed. After all, we're trying to learn how to actually go out and do it. Then, too, there are many different types of solar dryers which are successful and each one needs to be discussed. Each type has a value of its own. If it's a credible design and seems to work well, it shouldn't be ignored.

To get ideas for topics to be discussed on Chautauqua, I rely upon 1 istener suggestions, thumb through magazines and books on appropriate technology, and keep my eyes and ears open. Wherever I go, I just automatically keep a keen look-out for any possible topic ideas. If I hear someone talking about hulling locally-grown walnuts, I file that topic away in my mind or jot it down. If I hear someone say, "Yeah, 01d Joe Smith built himself a hand-made walnut huller," I'11 write down Joe Smith's phone number and follow up later with a call. 
There have been several times when I've hit dry spells in trying to come up with more topic ideas, but during these and other times the listener-suggestions have always opened up new ideas.

From the very beginning of the show I have always encouraged 1 isteners to write or call with requests and suggestions of program topics or guests. This has been an extremely valuable way to get further participation and criticism from the listeners. And once again, if a person suggests a topic they'd like to talk about, like building a solar greenhouse, somewhere out there is at least one person who has not only done it, but who would gladly talk about it.

When I first began Chautauqua I dreamed up about 20 possible program topics. Gradually, that 1 ist has grown way into the hundreds. The most important thing to remember is to be imaginative, try to come up with ideas in line with listener needs, and tailor the ideas to your area's recourees, climate, etc.

Since the day-to-day management of a show like this (producing i.t, applying for grants, etc.) can often get hectic, it's important to keep a list of future program topics so as not to forget a program idea. On my bulletin board, I keep a long list of future topics arranged by season. Often times in the dead of winter I'll think of a program topic which would be appropriate for summer. So I add it to the summer topics list and needn't worry about forgetting it. Also, at the end of a letter, a listener may ask: "By the way, could you please do a show on how to build a low-cost cider press sometime this summer or fall?" Once I've answered the letter, it gets filed away, and unless I've extracted the topic suggestion at the time, I'11 never remember it in the summer with so many other things on my mind. 
On the following pages are listed some of the specific topics we've covered during Chautauqua in Southeastern Ohio and West Virginia. Some of these topics may not apply to all regions of the country, nor to some city environments. So you'll want to tailor these and other topics to your own region.

Also, keep in mind the fact that as long as the listeners seem interested, you can discuss the same topic several times during the year. With radio, you may have different people listening from day to day. So by.doing two or three shows on solar greenhouses, you'll not only reach some new individuals who haven't heard the earlier shows, you' 11 be broadening your perspective on the subject throughout the year.

"I heard the program on bees and you of fered a list of books about bees and keeping them. Hould you please send me that list.

"ive also heard your program about horses, but we'd like to know mure about mules and oxen. How they work? Are they beller than horscs? We've heard they can work longer and aren't such a trouble to handle. Thanks a lot for your help."

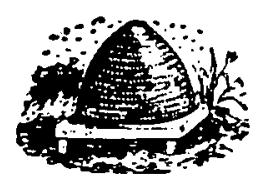

CS Ravenswood, W.Va. Hay 10, 1980

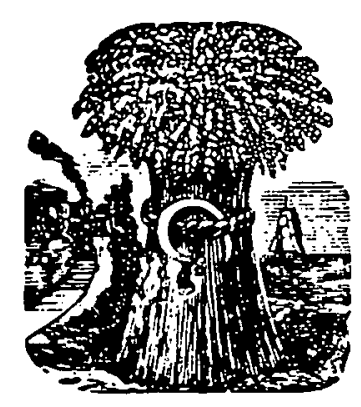

"Yould you have someone call in about the scythe for cutting hay or wheat. Where to purchase a good one and what brand name. I heard that they are expensive and that you can pay a lot for some that aren't very good, and also how to keep them sharp. Also, I'd like some information on working with mules or oxen and where I may be able to purchase them locally. I think your program is the very best. Thank you,"

BS Ravensivood, II. Va. May 8, 1980

"Thank you very much for the program on oxen. It was fust what we were looking for. We would have called in, but we had bad weather and live quite a long ways to a telephone to use. You asked many questions we did want to know. He have hilly land and woods that we wish to clear out and maybe grow some corn for our own use. .

"P.5. B. Smith is my mother-in-law. She's gone and gotten her a giond scythe blade now and is looking for a good handle now. She enjoyed the information you got for her. Thanks again."

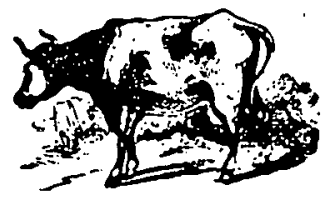

CS 


\section{Chautauqua Topics}

\section{ENERGY CONSERVATION :}

Resource recovery

Energy-efficient appliances

Energy-efficient owner-built homes

Energy-efficient water heaters

Weatherization and insulation

Building materials for energy-efficiency

Arkansas framing and other energy-efficient building practices

Energy tax credits (IRS)

Building storm windows

Jobs and energy conservation

Building and using a composting toilet

Regional recycling

Recycling around the home

Recycling/rebuilding old tools

Recycling innovation

Homemade hand tools from "junk"

Building with recycled building materials

Planting windbreaks and other foliage for conservation

Using local building materials

Small-scale brick manufacturing using local materials

Logging local timber

Insulation shutters you can build

Home cooling in summer; reflective shutters you can build

Evaluation of "gas saving devices"

Bicycling as a means of transportation

Organic/energy-efficient agriculture

Decentralized agriculture

Community gardens

How to build and use a solar cold-frame

Backyard gardening and pest management

Planting and propagating fruit trees

French intensive gardening

Permanent-mulch gardening

Preserving food: home canning, freezing, and drying of food

Building and using a root cellar for fruit and vegetable storage

Low-cost make-shift root cellars for food preservation

Raising grains on a small scale

Hand-operated tools for food harvest

Raising livestock

Preserving meat at home on a small scale

Building and using a smoke house

Composting

Growing nut trees as windbreaks and food sources

Hydroponics

City-gardening

Grey-water systems

Self-reliant living in the country

Self-reliant living in the city

Raising dairy goats, homemade dairy products

Raising dairy cows, homemade dairy products 


\section{ALTERNATIVE ENERGY SOURCES:}

Wind power for pumping water

Re-building old wind generators

New wind power systems

Energy-efficient wood heat stoves

Central heating with wood

Homemade wood stoves-design and safety

Masonry woodstoves

Woodstove and chimney safety \& how to clean your chimney

Wood cook stoves

Wood-fired water heaters

Building and using a fireplace-furnace

Woodstove pollution and how to reduce it

Heating with sawdust

Cooking on a wood heat stove and building a wood heat oven Wood-lot management and gathering $\mathrm{firewood}$

Heating with coal stoves and coal pollution

Building a low-cost solar water heater

Building a wood-fired and solar water heating system (dual source

Building \& using a "breadbox" solar water heater

Building a small-scale solar lumber kiln (dryer)

The community solar lumber kiln (larger scale)

Constructing a solar pond for a community heating system

Building and using a solar greenhouse (low cost)

The attached rock-wall greenhouse

Building a solar food dryer (low cost) for a humid climate

The Mine-Air Solar Greenhouse for community use

The solar window-box collector

Attached solar greenhouses for mobile homes

The mini-solar window-box greenhouse

Building and using a solar-still for alcohol fuel

Energy from Biomass

The 3-Cow methane fuel system (small scale)

Co-generation

Building an earth-sheltered house

Passive solar home construction

Trombe-wall construction

The Geo-Solar home

Generating electricity from small independent systems

Energy efficient water pumping, including ram-pumps

The stirling piston engine

Pedal power

Getting your small energy systems ready for winter

Hydropower

Horse-power for farming

Farming with mules

Farming with oxen

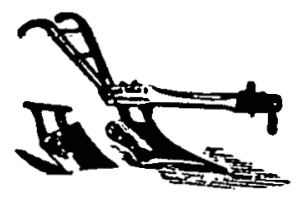




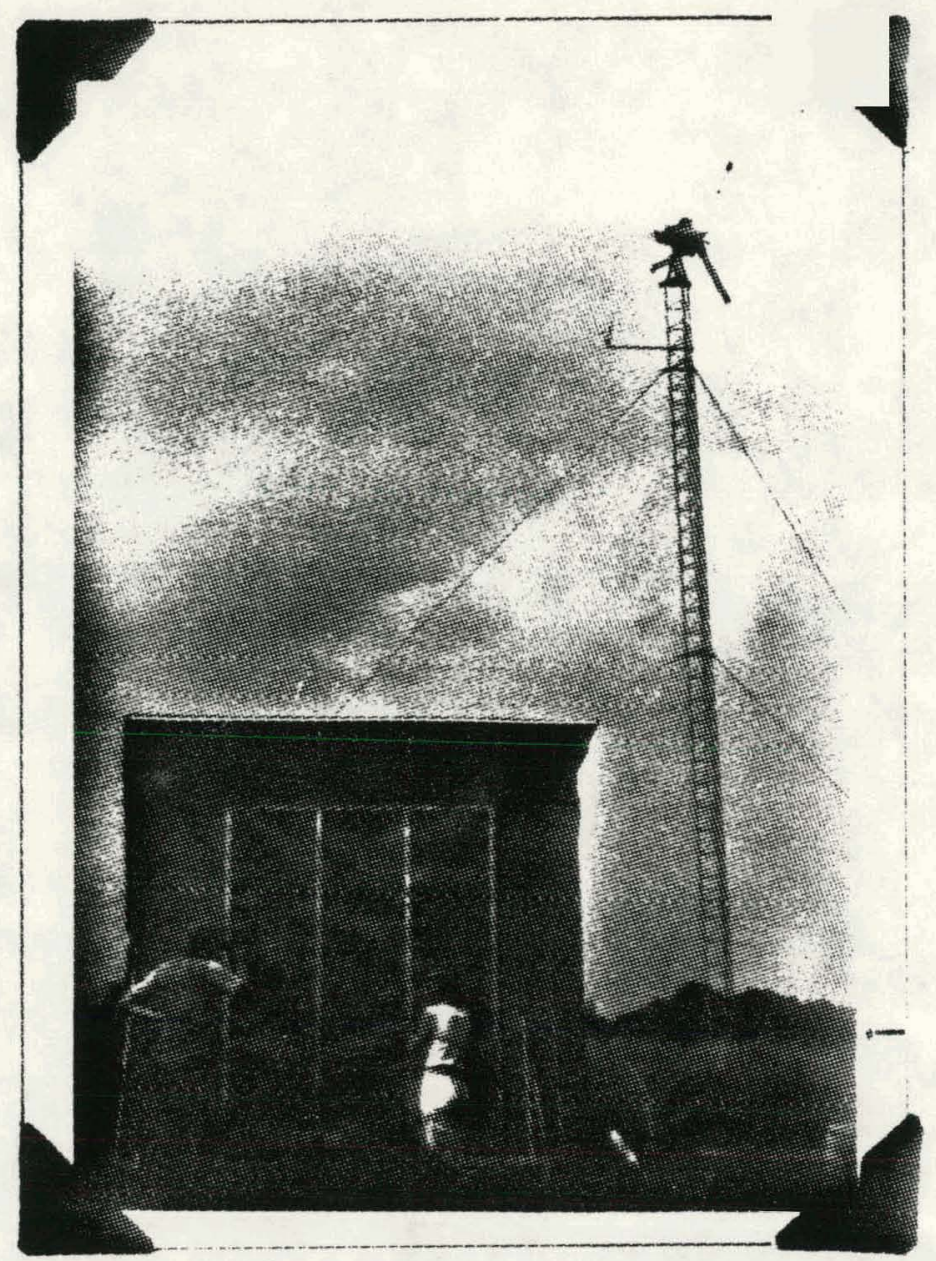

$C-6$

Solar-heated biuldiry for battery storage

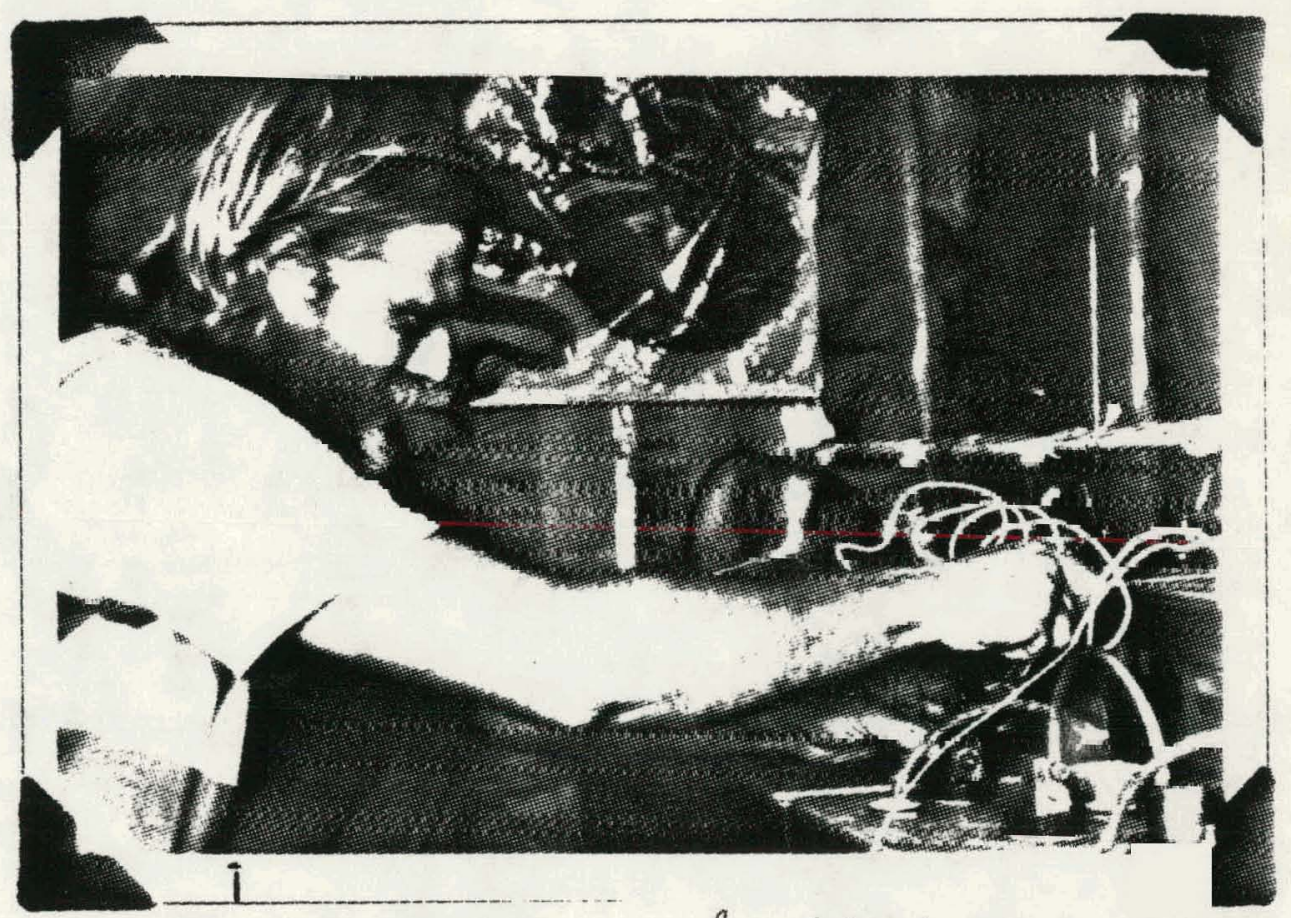

the storage batteries 

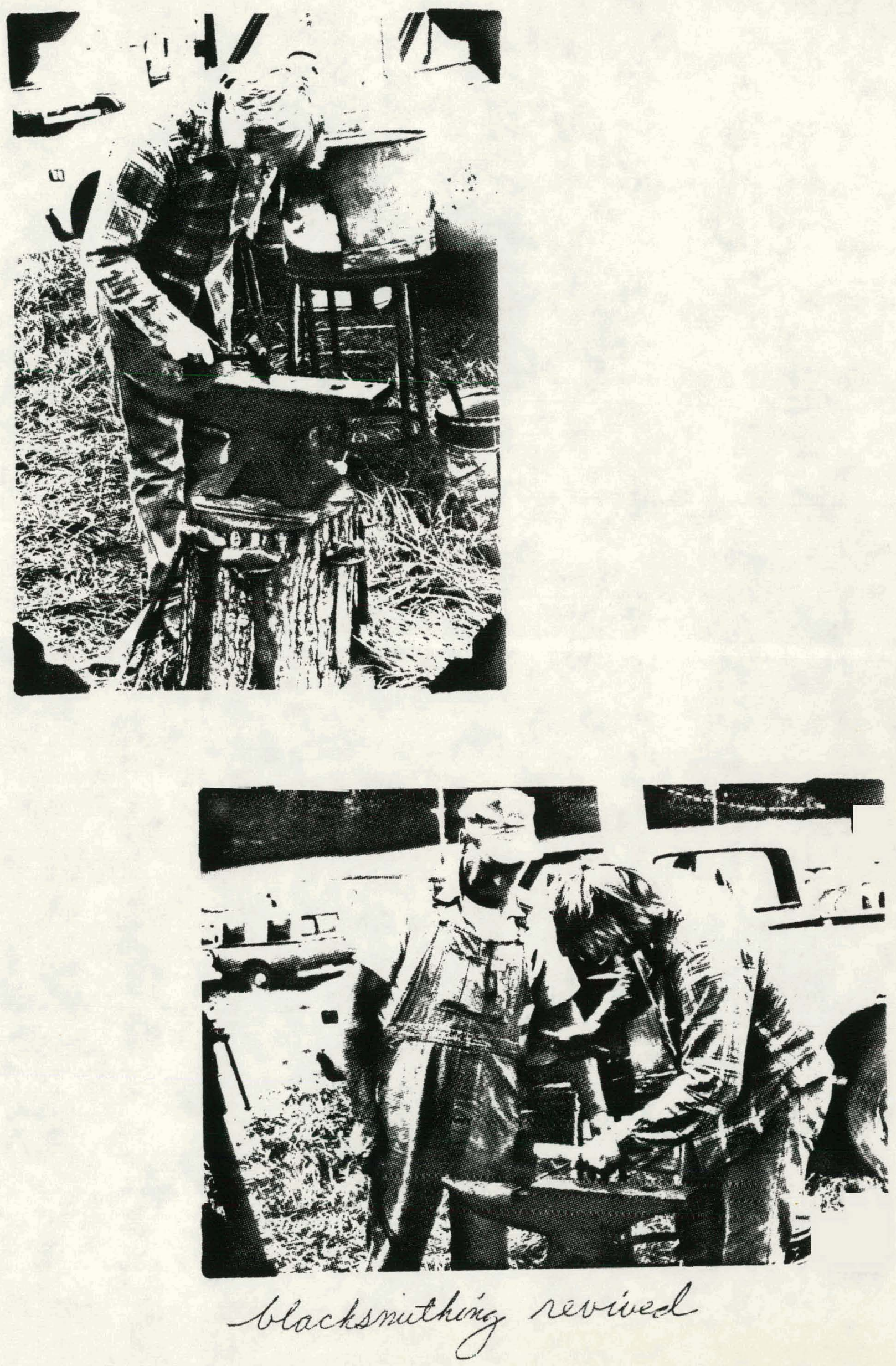


\section{Research}




\section{RESEARCH}

Once I've decided on a program topic, I've got to do a bit of research in order to know what kind of questions. to ask the guest, what kind of free pamphlets might be available to mention during the show, etc. Although researching windpower may take me off in a different direction from researching sorghum, there are some similarities.

Basic as well as extensive information is available in the form of pamphlets, magazine articles, and books at your local library, news-stand, or bookstore. When beginning your own version of Chautauqua, you would do well to establish a reference library in your office. or home which includes some good reference books, magazines, pamphlets, and reports which are in line with the topics you'11 be researching.

I have had great luck in gathering lots of free reference books and other printed material to help build the Chautauqua reference library. When I first began producing the show, I wrote to several publishing houses which had a selection of books on appropriate technology, described Chautauqua, and explained my need for reference material. I included a list of topics (like greenhouses, growing and preserving food, alternative energy, hand-made tools, etc.) and asked for complimentary copies of any appropriate books they might think helpful. Although I make it clear in my letters that Chautauqua is broadcast over a non-commercial radio station and can not advertise in any way, quite a number of publishing companies have donated books on topics ranging from "insulating your home" to "growing food in your solar greenhouse." 
I have also written for numerous free publications and reports put out by the U.S. Government. Be sure to check with your own state government, county extension office, soil conservation service, forestry service, etc. for free material on a variety of topics.

Brochures and leaflets from utility companies which 1 ist "energy consumption charts, figures, etc." and pamphlets from other industry groups have also proved to be a valuable reference tool. Needless to say, any free materials which you receive from the government, corporations, or special interest groups are likely to contain subtle and sometimes not-so-subtle biases. Be forewarned.

In conjunction with my own Chautauqua library, I also make regular use of our local university libraries and city libraries. If your library does not have an extensive collection of materials you need, see if they can't order them for you through "Interlibrary Loan." Even many smaller libraries take part in the Interlibrary Loan system in order to tap the resources of larger, regional libraries.

Also, don't be shy about asking your library to buy specific books. Most librarians welcome requests from customers to help them choose their new books. And if you explain that you'11 be referring to certain resources "on the air," your library should certainly understand the need for having such books available for your local listeners.

For magazine articles and reports, the Reader's Guide to Periodical Literature is an invaluable tool. Arranged by year and subject, it is a regularly-updated easy-to-use index of magazine articles. If I'm looking for information on pollution created by burning wood in a wood stove, I'11 
go to the Reader's Guide and look up wood heat, wood stove, pollution, or some similar category and find several good recent articles 1 isted.

Although much of the information you'll want to research will appear in current magazine articles, keep in mind that some of the information you'l1 be researching isn't new at all (nothing new under the sun, etc. etc.) Much of what we call "appropriate technology" is actually long-existing technology which has simply taken on a new importance.

For how-to-do-it information which knows no time barrier, I have found old copies of Popular Mechanics and other similar magazines to be invaluable. One rainy day I went through many old issues (starting around 1927) and found literally dozens of pertinent articles, plans, etc. In fact, to my delight, I stumbled onto a design for building a drying oven for fruits and vegetables which was attached to a wood cook stove-something for which I'd been searching for quite some time.

Few people realize that the United States Government is actually the world's largest publisher. It cranks out millions of pages of information each year. And many of its pamphlets, reports, studies, and books are quite readable. Each year the Government designs more and more material for the average consumer.

In order to make its publications more readily available to the general public, the Government has established several hundred Government Document Depositories around the country. If your area's local university library is fortunate enough to have a Government Documents section, you have access 
to a gold mine of information. In addition to providing you with lists of pamphlets and publications on everything from solar food drying to insulation shutters, it also houses thousands of publications which listeners might be able to order from the Government Printing Office.

Last, but perhaps most important in researching for Chautauqua is the valuable information which people have to offer. While researching a topic, I'll often call someone either in our region or elsewhere in the U.S. For example, when I was considering doing a show on the "earth-sheltered pre-fab log home kits" being sold in our area, I wanted to check out the construction practices and materials used in these homes. So, after receiving the specifications from the distributor on these homes, I called a local top-notch carpenter in order to get some specifics. on this type of construction. Most people I have called while researching topics have been very helpful and willing to share what they know with me.

Once you've thoroughly researched a topic, you should have little trouble coming up with appropriate questions to ask the guest. As is so often the case, the more you learn about something, the more you realize you don't know. And that, of course, is where the guest comes in.

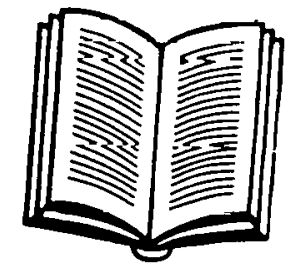


Guests 


\section{GUESTS}

From experience, I have found that the most successful Chautauqua interviews have usually been with "normal" everyday people who have some enthusiasm and know-how to share on any given subject.

There are, of course, many "professional experts" available on various appropriate technology topics. But then, too, there are hundreds of enthusiastic and spontaneous "amateur experts" who have learned either by doing, or perhaps out of necessity. For example, I have had great luck in generating a lively discussion with enthusiastic individuals who learned on their own how to build a cold-frame for growing vegetables in the winter. The listening audience responds spontaneously with this type of guest whereas they might be "put-off" by a more academic "lecture-type guest." As long as the information is credible, reliable, and authentic, I go for the more down-to-earth approach.

There are many organizations or offices in each area of the country which can help you make contact with a guest to discuss any given topic. If you're looking for someone who has grown grain and distilled alcohol fuel on a small scale, a local County Extension Agent may know of someone; or, a local consumer group, co-op, or energy group might be able to help.

Also, since Government agencies often give grants to people to do research, they may be able to provide you with a list of people in your area who received grants to build and operate a still for fuel. Check with the nearest Federal Information Center for help.

One call. leads to another and although you may have to make quite a few calls to find someone knowledgeable, he or she certainly exists. 
If you're at a dead-end and seem to have exhausted your avenues for finding a specific guest, then turn to your 1 isteners. At the end of your show one day just say: "I'm looking for someone who has built and used a still to make alcohol for use as a fuel. I haven't had any luck finding anyone, so if you know of such a person, drop me a note and let me know who it is. The address is. . ."

Every once in a while you may be unable to find a guest in your area for some of the topics you're trying to line up. If that's the case, don't despair. One of the wonderful things about a call-in show is that you can call-out, too. If you can find someone in another part of the country who has built a solar still, then line him. up for a long-distance interview.

You'1l find that most people will be willing to do telephone interviews with you since it requires only about an hour of their time and they don't have to travel anywhere. Again, it makes great use of radio and telephone technology. The guest can share his or her information with thousands of people without leaving home, traveling, using more energy, etc. And the important thing is, even though the guest may be from nutside your region, he or she can gear their comments to your local resources, climate, etc. and provide your listeners with important and useful information which isn't readily available in your area.

Sometimes, long-distance interviews seem impossible simply because of the time difference between regions in the United States. For example, when Chautauqua goes on the air at 9:00 in Ohio, it's 6:00 in California. Not many people would be willing to do an interview at $6 \mathrm{a} . \mathrm{m}$. However, since we're still a fairly mobile society, chances are that the person you want to talk to will be 
traveling to another part of the country sometime in the not-too-distant future. You' 11 find this to be true especially if the person to be interviewed is a writer, lecturer, or if they travel for business reasons. So, check her or his travel schedule and arrange a long-distance interview when they're visiting a part of the country that's in your time zone.

When searching for guests for your program, always keep in mind the fact that even though you may occasionally have to call outside your own region to find them, the person you're looking for does exist. It's just a matter of tracking him down. And in many cases, someone you know already knows him.

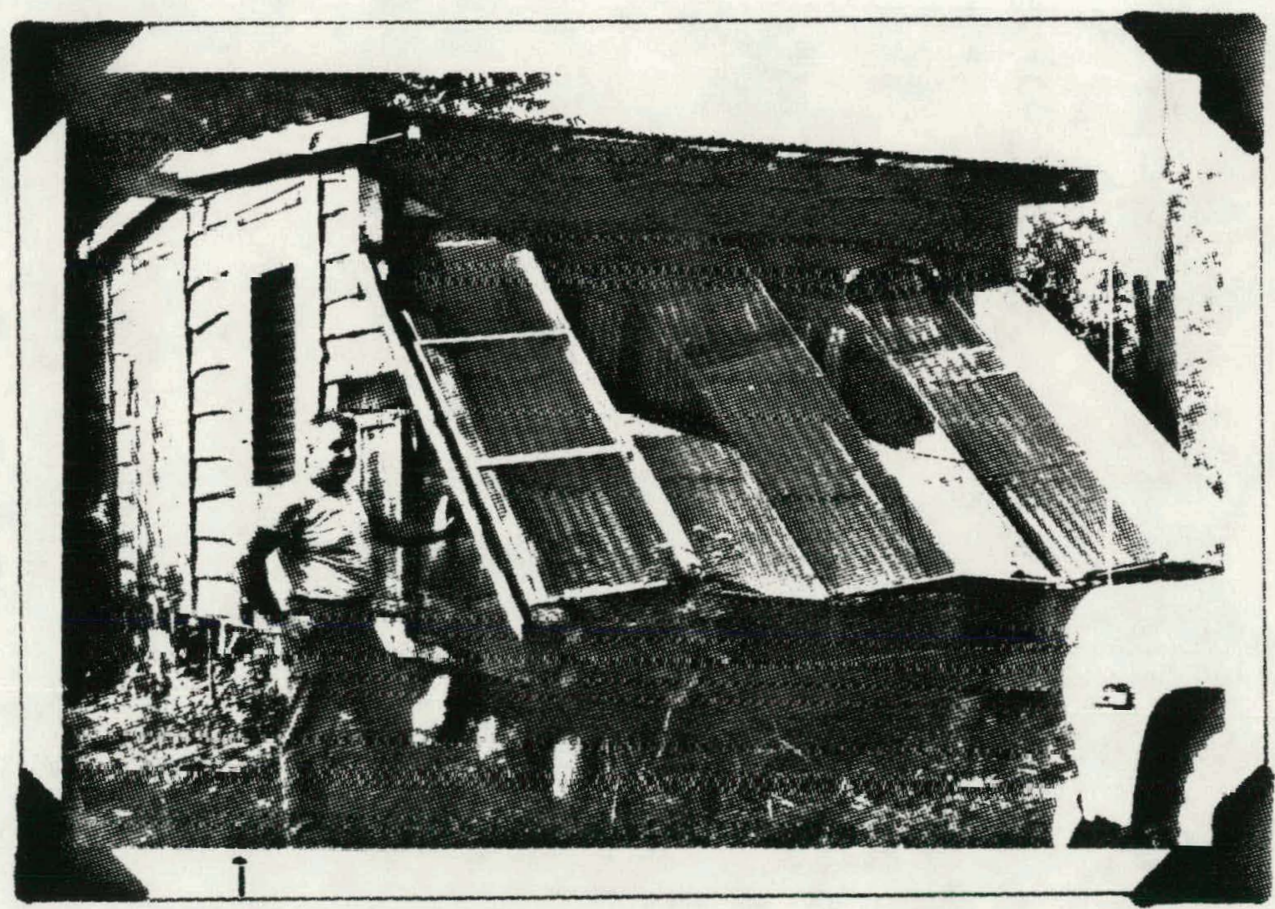

Solar lumber kiln 
FROHA A FOUR-PACE LETTER:

Dear Bobbi,

When I can remember I try to tune in your radio program so I can listen to it when I am at my job. When I tuned in at 9:20 today I heard you mention you were looking for people who had built their own houses but who previously had no experience. That's us!

In 1975, three other perple, plus me part time, assembled on our 10 acres of roods in order to clear an area for a garden, buy a sawmill, log and saw wood for a sawmill shed, a garage, and a $15^{\prime} \times 40^{\prime}$ cabin. In the fall of 174 , the men were here to develop a water system, build a bridge and clear out an old rotted log cabin.

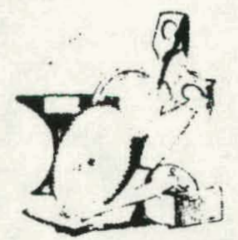

Because we had very little experience building, we built the garage and shed first to work out some mistakes before tackling the cabin at the end of that first full season. .

$\mathrm{BZ}$

Kellston, $\mathrm{OH}$

October 12,1978

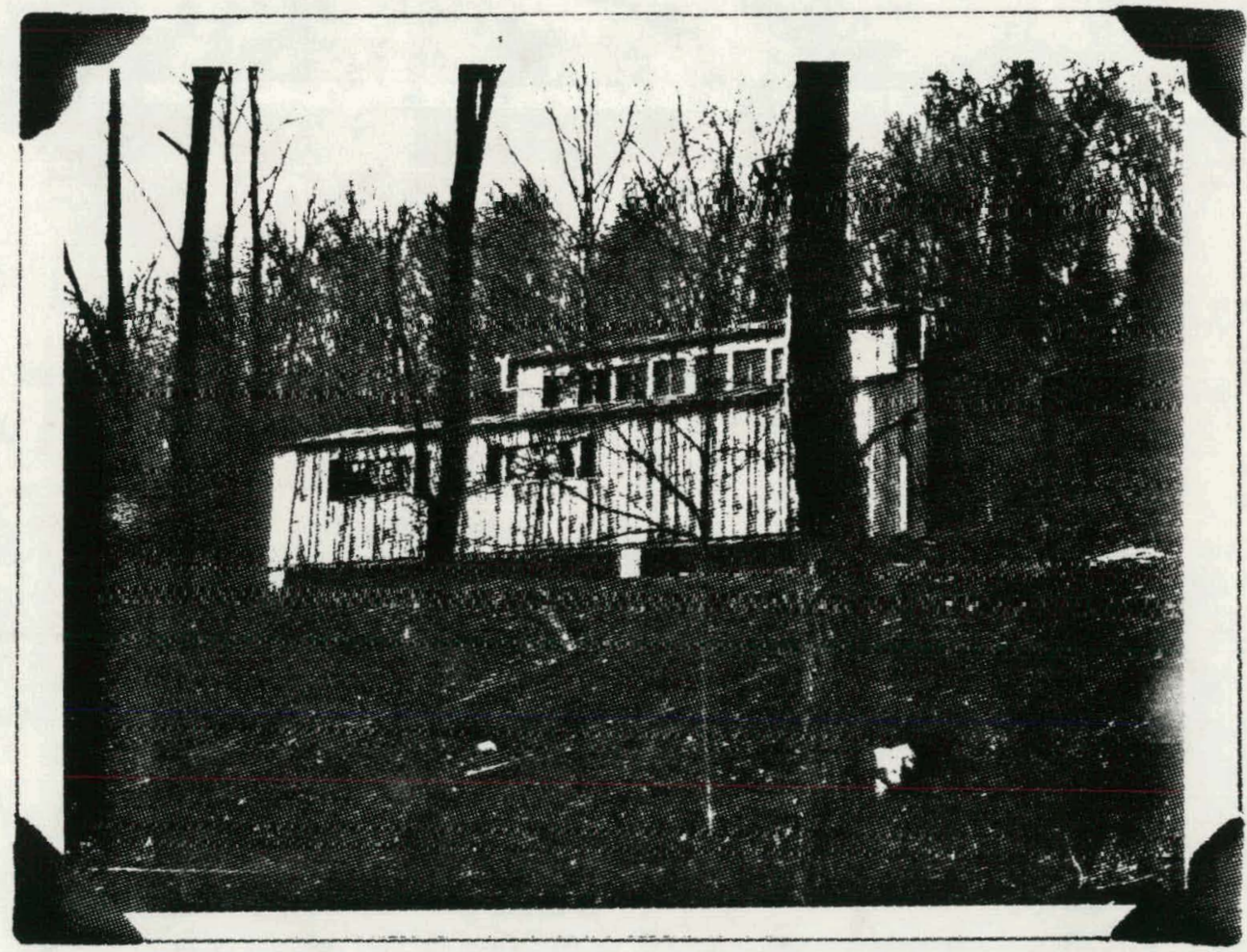




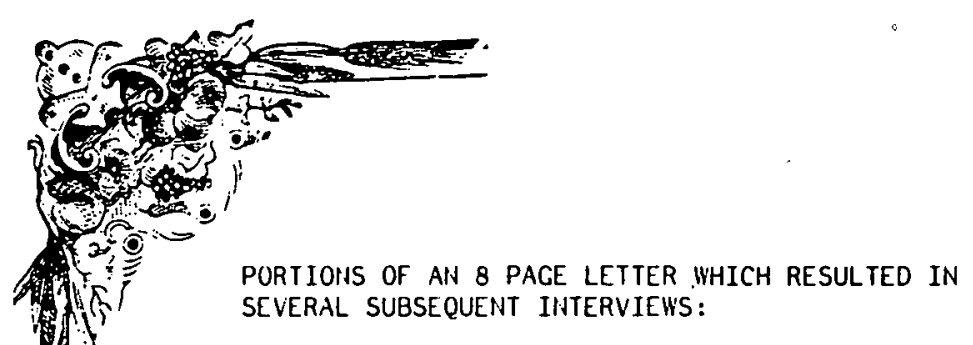

Dear Bobbi,

I've been listening to your program since Christmas

when we finally gol a bullery opcralce radio. I elljoy il so much as it of fers a daily reminder of the reasons and ideals behind our move to the country.

Today you were discussing methods of saving electricity. Since we have no electricity, and no phone, I thought I'd write to you about our experience of living without it.

lie bought our land 3 years ago, and at the time planned to have power run in by the electric company. After awhile we realized that the sources from which most electricity is derived were stripped coal and nuclear power, both of which we are strongly opposed to. Coupled with the high cost $(\$ 3000$, refunded to us in three years) of installing power, we decided against it.

So when we designed our house, it was with the idea in mind of making it as easy to live in as possible without electricity. He built it so that we take advantage of sunlight as many hours of the day as possible for lighting, as well as heat. The floors

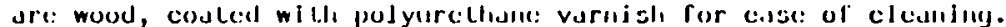
We are building in most furniture for practicality as well as ease of cleaning. We use regular kerosene lamps for light, plus a powerful hand lantern. The easiest way to live with kerosene lamplight is to plan to do very little in the evenings, and not lo have to luok. for anytlisig at night! All our walls are white to give added reflection to our lamps, so it's really fairly bright in here in the evenings.

We put in as few interior walls as possible to aid in air, heat, and light circulation, as well as to give a feeling of spaciousness. He heat with wood, except on days that are sunny or even partly sunny, when the sun does the job for us. As I write this, it's about 7 degrees outside, and 70 degrees in here, and our fire is out. Because of good air circulation, we can heat our 1100 square foot house with a Franklin fireplace. Our shed roof design, with a 13-foot front wall, and 9-foot rear wall, and high ceilings, probably is the reason for the air circulation, although $I$ know this is contrary to most ideas. I think that because our fireplace is located in a lowered (sunken with built in couches) section of the living room, it keep's the floor warmer. And because the chimney goes straight up in the higher section of the house, is metal and open to the room, the heat from it drains down the ceilings into the lower-roofed section of the house. Just a surmise, but it may be true. 
Vie cook on either our wood cookstove or our L.P. gas stove, and heat our water with LP gas. With 4 boys, hot water is a must for me! I wash clothes in an automatic washer powered by a gasoline generator, use a treadle sewing machine, or sew by hand, which I enjoy. Instead of television, we're all reading freaks; although the youngest two can't read yet, they like to look at books. So evenings are spent reading, talking, sewing, or playing games such as bingo, checkers, etc. together.

Our water system is a little strange. We found we have a really good (1000 gallons a day) spring on our farm, but it was located below the place we decided to build, and about $1 / 4 \mathrm{mile}$ away. So we piped the water downhill to a holding tank (1300 gallon capacity). It gravity-feeds into this tank, which is located about 200 feet from our house. We put in a submersible pump in the tank and once a week using our generator, pump the water uphill to another 1300 gallon tank located above our house by about 30-40 feet. This water then gravity-feeds down into the house, and gives us pretty strong water pressure as well.

Our gasoline generator is a handly little critter as it's light enough to be moved easily and enables us to use power tools when we need to.

We have lots of plans for making our life more energy independent. He've only been on our farm for a year, and have much to do.

In our plans are a wind generator to power the pump and washer, a root cellar with a special "cold box" which we can fill with cold spring water daily, to keep milk, etc., cool in hot weather. Buying our kerosene in 50-gallon lots so as to get it for less than $50 c$ a gallon, solar collectors for heat and hot water, and so on. We're also planning to build a solar heated greenhouse.

All this will take time, and we realize that it may be 10 more years before we accomplish what we want to do. But half the fun of anything is the planning and the work involved in getting it done.

As regards to how comfortable life is without electricity, we find it to be just fine. I don't miss any of the normal household electric appliances. H'e never were much into that stuff anyway, and when we knew we were moving here to live without power, we started uropping off electrical items one by one.

One of the most pleasing aspects of this way of life is that power outages in no way affect us. During all the recent snows, while so many people suffered from breakdowns of power supplies, we were snug and comfy. And al though we were snowed in for 3 wecks, and had to pack in anything we needed from a mile away, we suffered no hardshlp at all. 
There is a great feeling in being independent like this. Sure, we buy kerosene, batteries, and gasoline. But if necessary, we could do without even these energy sources by carrying in our water and lighting with candles and so on, and would still live comfortably. I think the main evil of electricity is that people get hooked on it. The thought of doing without it causes a panic. Folks feel helpless; somelimes 1 think America is a power "jurikic!"

Most folks think of not having electric as having to live primitively. Not so. As a matter of fact, most people are very surprised at seeing our house when we tell. them we don't have electric. Only the lack of lines outside and switches inside gives us away.

You're more inventive and creative without it, too. You think of ways to get around things, new ways of doing things and so on. I personally enjoy using hand operated tools and kitchen tools. Some of the old-time kitchen gadgets make so much sense, like hand powered churns, apple peelers, egg beaters, stovetop corn poppers and so on. There's absolutely no need to do so many things electrically. I would never go back to living with electricity again, unless it came from our own source.

Our boys, who ranne in ange from 4 to 8 , don't seem to mind

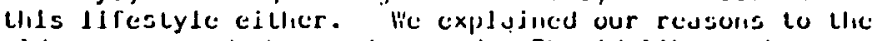
older ones, and they understand. They'd like to have a IV, sure, what kid wouldn't, but it doesn't bother them much. There's so many other things to do, walks to take, wild animals to see, sledding, and their work, that they wouldn't have time for it, anyway.

And what a relief to know that we, at least, aren't contributing to the national energy problem!

- Enough for now. I'll be listening every day, and wishing you well.

Blue skies and sunshine,

$\mathrm{SF}$

Sandyville, W.Va.

February 1, 1978 

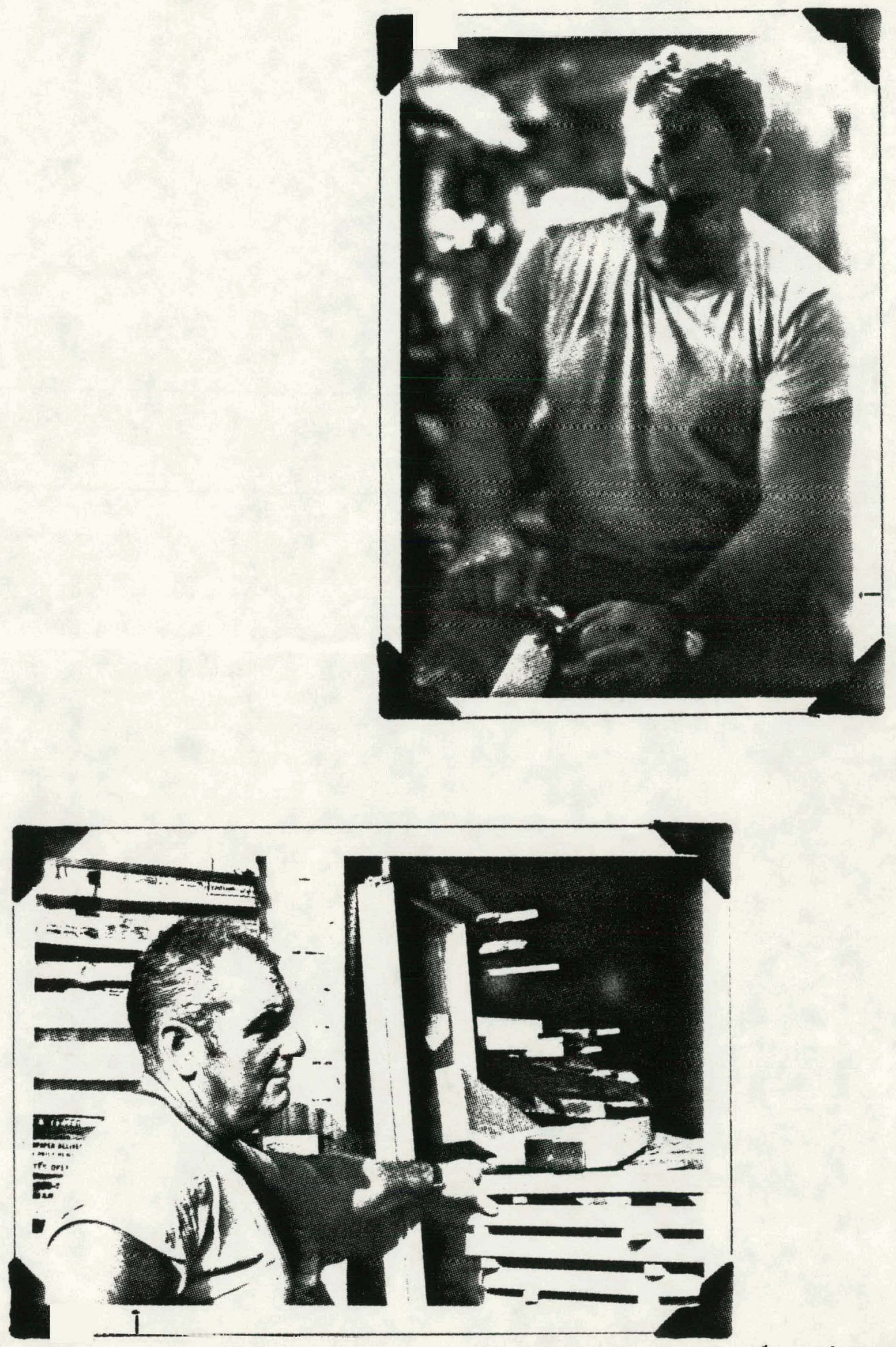

wood drying inside the solan lumber hiln 

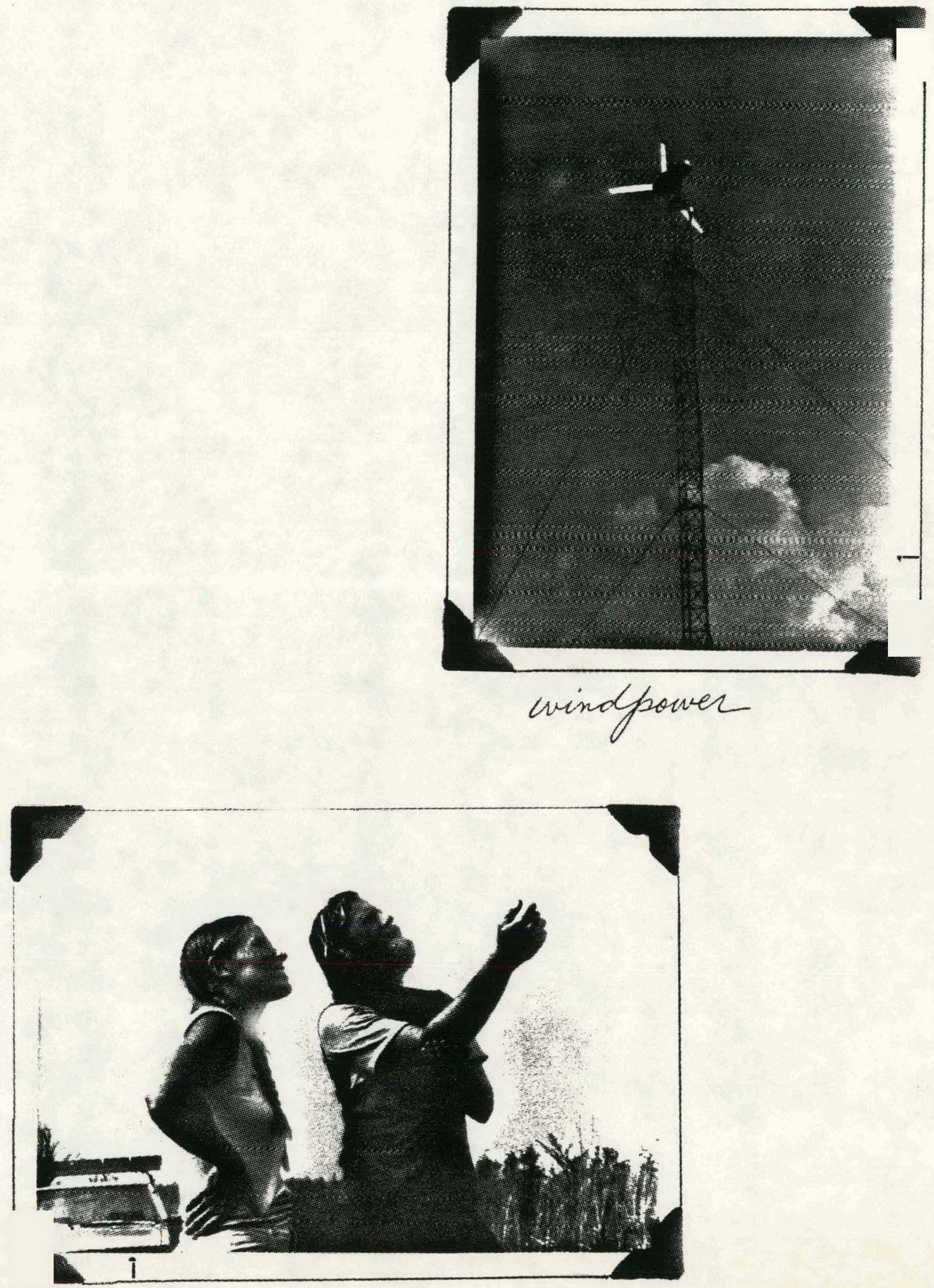

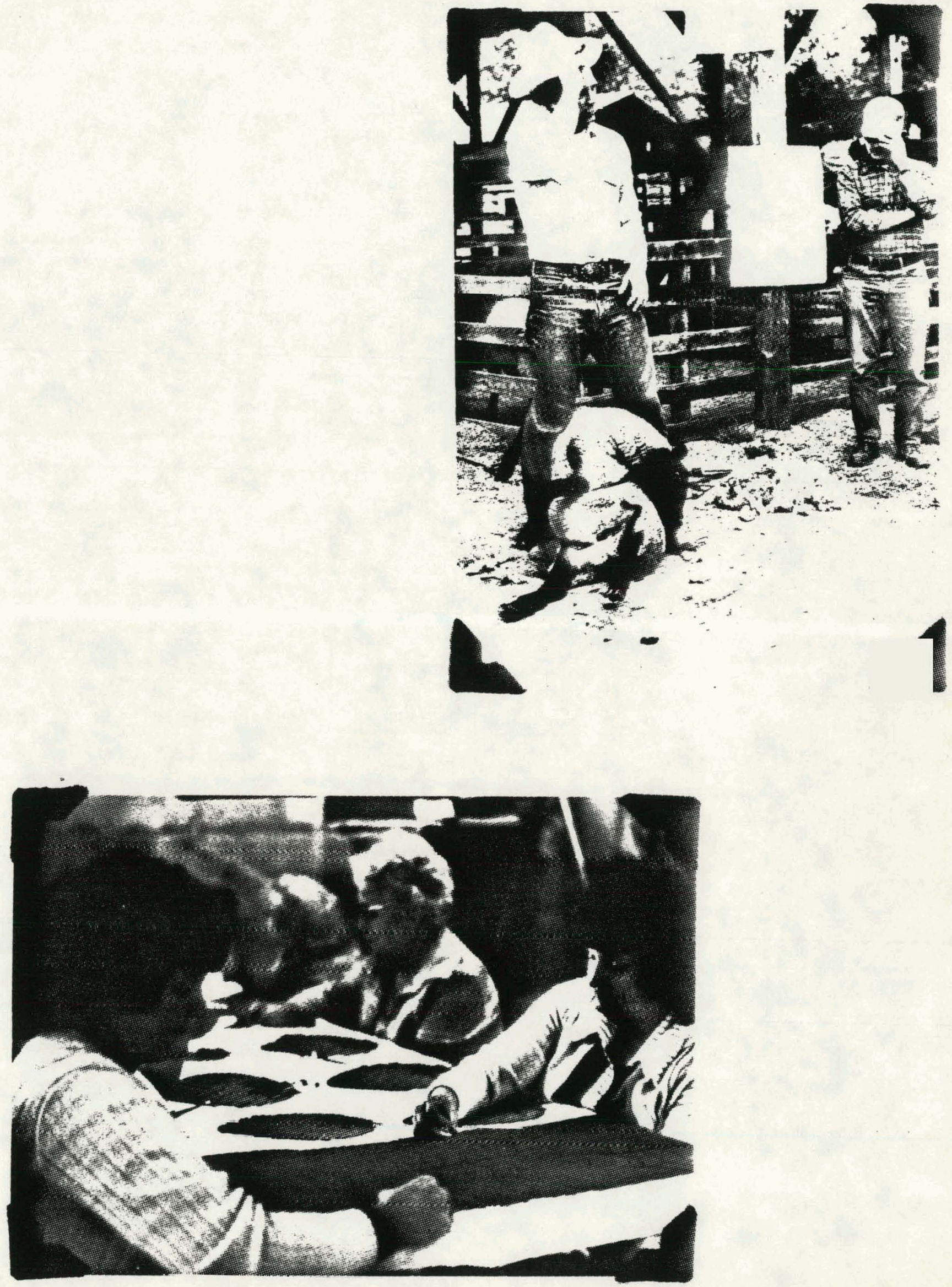


\section{Interviewing Tips}


As the host for Chautauqua, it's essential that I ask questions for all the people listening who are genuinely interested in and curious about the topic. If, for example, I'm interviewing someone about windpower, I've got. to be sure to ask questions designed at getting information on how-to-do-it. There will be people listening who are attempting to build a wind-generator, or looking to buy one, or who are just beginning to consider switching to windpower. I will do a great injustice to all these people and to the knowledgeable guest on windpower if I ask shallow, conversational questions (or small talk) rather than in-depth, well-thought-out questions which really attempt to get at some hard-core information.

Now then, I'm no expert on windpower, so how do I become knowledgeable enough to conduct an interview on windpower? First, of course, I conduct my basic research. Then, I assume a curious frame of mind and think through wind-generators as if I were going to buy one, or build one, or use one: Where do I begin? What do I need to know, etc. From there, a hundred questions come up. Should I build or buy one? A new or used one? How do I find a used generator? Can I, as a layman, rebuild a used generator? Where do I begin? What parts wear out? How long will it take? How should I choose a site for my wind-generator? How tall should the tower be? How do we erect it? Where can I find low-cost storage batteries? How do they work? How do I vent them? What temperature should my battery storage-building be? And on and on and on.

of course, listeners will also begin calling in with their own questions and information, but. as host for the show, I must represent the interested listener in an effort to take advantage of the great experience and knowledge the guest has to offer. 
Once I've got a list of questions, I prepare a general outline for the interview. Pre-determined questions and an outline can lend structure to the interview so that you proceed along a logical path. But don't over do it!!! It's absolutely essential to remain flexible and that you add new questions which come to mind during the guest's responses. I've seen many interviewers miss the boat because they dreamed up ten questions for an interview and stuck to only those ten no matter what transpired in the course of the conversation. As a result, they missed the most significant part of an interview.

Remember, it's especially important to conduct an interview from a curious point-of-view or frame-of-mind. And that means you must listen carefully to what your guest is saying. Careful listening and curiosity will go a long way towards assuring a smooth interview.

Beyond that, I try to ask questions aimed at uncovering detailed information. When you're conducting an interview on building a masonry woodstove for example, you've got to get down to the nuts and bolts and step-by-step of how-to-do-it. If you simply skim the surface, you may leave out critical information which leaves the listeners hanging in mid-air without the necessary details.

Many subjects which we discuss on Chautauqua do require some additional research on the listeners' part, or perhaps a vieual aid, photo, etc. to accompany the verbal how-to-do-it description. But none-the-less, if you're thorough in your questioning and the guest is descriptive in his or her reply, you can go a long way on a verbal description or explanation.

I have found a down-to-earth and informal style of interviewing to be very important in gathering information 
from all sorts of people-self-taught, college educated, people from other countries, young and old. I, myself, feel most comfortable by just talking in a normal way, just as I would talk with a friend over the telephone.

Many people unfamiliar with microphones and who are already a little hesitant about "being on the radio" will clam up (or perhaps refuse an interview) if you approach them in an impersonal or highly businesslike way.

Again, I tend to interview "amateur experts" (normal people) who are unaccustomed to being in the limelight of radio or television. So I must do my best to assure potential guests that Chautauqua is intended to be a spontaneous and personal exchange of information. It's the information and experience which the guest has to share that's important-not how sophisticated or rehearsed their presentation. This informal conversational approach has helped to make not only myself and the guest comfortable, it has also helped to make the listeners more comfortable about calling in to share their ideas, questions, and information "on the air."

This leads me to the subject of terminology and choice of words. First, I should say I don't have an unusually extensive vocabulary. But beyond my limitations in vocabulary, there exists a commitment to plain, simple language. I try not to use many new slang expressions. I've found you can easily alienate someone who has wonderful information to share if you're using phrases, slang, and terminology that are unfamiliar to them.

Several years ago, I sat down with my grandfather who had been around gardening and farming for nearly all of his 80 years. Since he grew up on a small hillside farm 
in the mountains of Virginia, I'd found him to be very knowledgeable on growing vegetables and fruits on a small scale; making the most of the land available.

On this particular day, I asked, "What can you tell me about Organic Farming?" He was silent for a moment, then shook his head and said, "I don't know nothin' about that kind of farming." And I said, "Sure you do, you've told me how you used to turn corn stalks and manure into the soil and how you used to plant your potatoes on top of the ground in old hay or mulch and how you used to plant radishes in among your cucumbers to keep cucumber beetles away from the cukes."

"We11," he said, "that's just plain farming. You used what you had to grow them things and spread the manure on it in the fall as fertilizer and turned it under."

"We11, that's Organic Farming," I said.

"We11, I don't know nothin' about that kind of farming. But this is how everybody used to farm." And so the conversation went.

Finally, I wised-up and said, "Well, tell me all about how you used to farm and what you used to grow there." And there came an incredibly rich flow of information. . descriptions of every conceivable vegetable and fruit planted near the Big House. Mountain in Virginia. I learned just how these crops were planted and nurtured and harvested. And now we talk "just about farming," (or how they grew food before they had chemical fertilizers, pesticides, etc.)

As if I hadn't learned my lesson in plain English from. this conversation with my grandfather, in the spring of 1979 
I did a telephone interview with Ruth Stout-wel1-known author and gardener who has promoted the "permanent mulch" method of growing foods without cultivating. At the time, Ruth was 95 years old. Early on in the interview, I said, "So you never 'till' your garden" (meaning rotary-tilling which is a relatively new expression.) And Ruth said, "What does that mean, "till"?" And I said "rotary tiller". . . another pause. . . then I said, "a power tiller" (there it is again). . "a cultivator!" "Oh, a cultivator. . . Oh, no, I don't use a cultivator."

I must further confess that although Chautauqua is a program about various "appropriate technology systems," I have rarely uttered that term on the show. I realize that some of the most experienced people, in small energy systems and other appropriate technology topics may be lost by my choice of this contemporary expression. So, instead, I simply ask for information on wind-generators, or ways to pump water with a ram-pump, or a system which doesn't require electricity, or ways to store garden fruits and vegetables without using energy, etc:

In short, I've found that the hest way to conduct a successful interview is to research the topic, make a general outline and a list of potential questions, listen carefully, maintain a curious frame-of-mind, flow with the conversation, and stay away from slang or fancy terminology which might alienate the guest and the listeners.

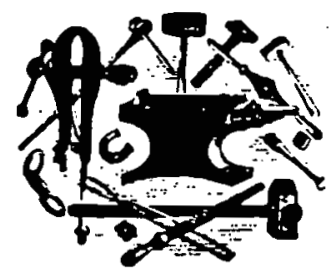




\section{Listeners}




\section{LISTENERS}

What actually makes Chautauqua a success, of course, is the participation of its listeners who represent a never-ending storehouse of knowledge. Unfortunately, while everyone has something to share, some people are fearful of "going on the radio."

Getting people used to the idea of calling in "on the air" to share information with others was one of the biggest hurdles I had to jump during the first year of the program. I tried several things in order to break the ice: some successful, some unsuccessful. From trial and error, I learned a few tips that proved to be effective tools for encouraging listener participation.

From the beginning, promote the show as an informal "information exchange." This can be done each day in the introduction of the show simply by saying something like, "Give us a call this morning if you have some ideas or information to share with others in Southeast Ohio and West Virginia. Today, we're hoping to hear some of your ideas on. . .building a solar water heater. We'11 be talking to Fred Williamson this morning about the solar water heater he built and we're hoping to hear from other people with different designs or materials as well as any questions you might have. Our phone number : is if you like." and remember, you can call us "collect"

Try to convey the idea that everyone has something to share on one subject or another. The guest on any given show has specific knowledge, but then, so do other listeners. It's important to promote the aftitude that everyone can contribute. 
On the days when there is no guest on Chautauqua, we rely almost entirely upon listener know-how to carry the show. During these days it's essential that listeners participate in the show. I experienced many uncomfortable mornings trying to persuade people to call in before I realized that others seem to feel more comfortable calling in after one person breaks the ice with the first call.

Finally, I discovered that I' could "break the ice" by initiating the first call simply by calling-out to someone for a few minutes. For example, if I were doing a miscellaneous show covering several related topics (such as wood-fired water-heaters, wood cookstoves, and ways of using wood ashes around the home and garden) I found that if I phoned out for a brief chat with a fellow I had heard about who built his own wood-fired water-heater, it would get things going.

Then, as soon as he hangs up, I encourage others to call in. Sometimes this fellow may have mentioned several problems he's had in trying to work the "bugs" out of his water-heater system and this often encourages others to call to offer some possible solutions.

Having a tangible request for specific information like this really motivates people to call. It's a pleasant experience to witness the willingness of people to help others in this way. And at a time like this, the desire to lend a helping hand to another person often helps people to overcome their shyness and reluctance to be "on the radio." 
Unfortunately, some people listening to Chautauqua can't call in to participate for one reason or another: they don't have a phone, or their party line is busy; they're driving in a car, or they're working in some other location without a phone.

Realizing this, I've always encouraged those people to participate in the show by writing letters. When listeners write to me with some information which they want to share, such as using sawdust as a mulch in the garden, I pass it along on the show at the first appropriate time. And when people send in questions, I relay them to the other listeners and we generally receive a response on the air; hopefully, the listener is listening for the answer.

Also, I try to promote upcoming shows in advance so that those people without a phone can write-in their related questions in advance of the show. Then, I remember to ask these questions of the guest during the show.

In addition to receiving information, questions, and inquiries in the mail, I regularly send out information, addresses, free pamphlets, names of contacts, etc. to listeners who request it.

For the benefit of those traveling in a car and for others who are unable to copy down addresses and other information given out on the air, I regularly invite listeners to write to me for any information they've heard on the show but were unable to write down. And we really do get a lot of mail requesting information of this sort.

As host of the show, I see my role as a "go-between," and am more than happy to respond both on and off the air with the information necessary. to put people in touch with others who have knowledge and resources to share. 


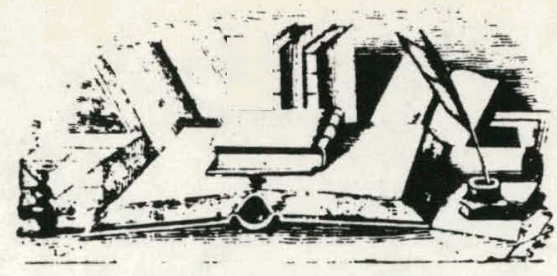

". . I'm still listening to your program everyday. Would you please send me the recipes for chicken scratch feed, also the one for Homemade laying mash. He don't raise chickens anymore but a friend of mine raises them so I told her I'd get the recipes for her.

"Here are a few things also: Eggshells are good to feed back to chickens. Geese are good for letting kill bugs in gardens and also will weed the garden if you let them in while weeds are just starting to come up. Cows that are eating and licking bark on trees are lacking minerals and probably salt. To get a good supply of fishing worms in your yard and garden throw your coffee grounds and some sugar around. This really works. We have plenty now. Pancake mix and beer make a good batter for frying fish and it makes a thick crust. Better close for now. A listener."

PJM

Caldwell, $\mathrm{OH}$

Harch 31, 1980
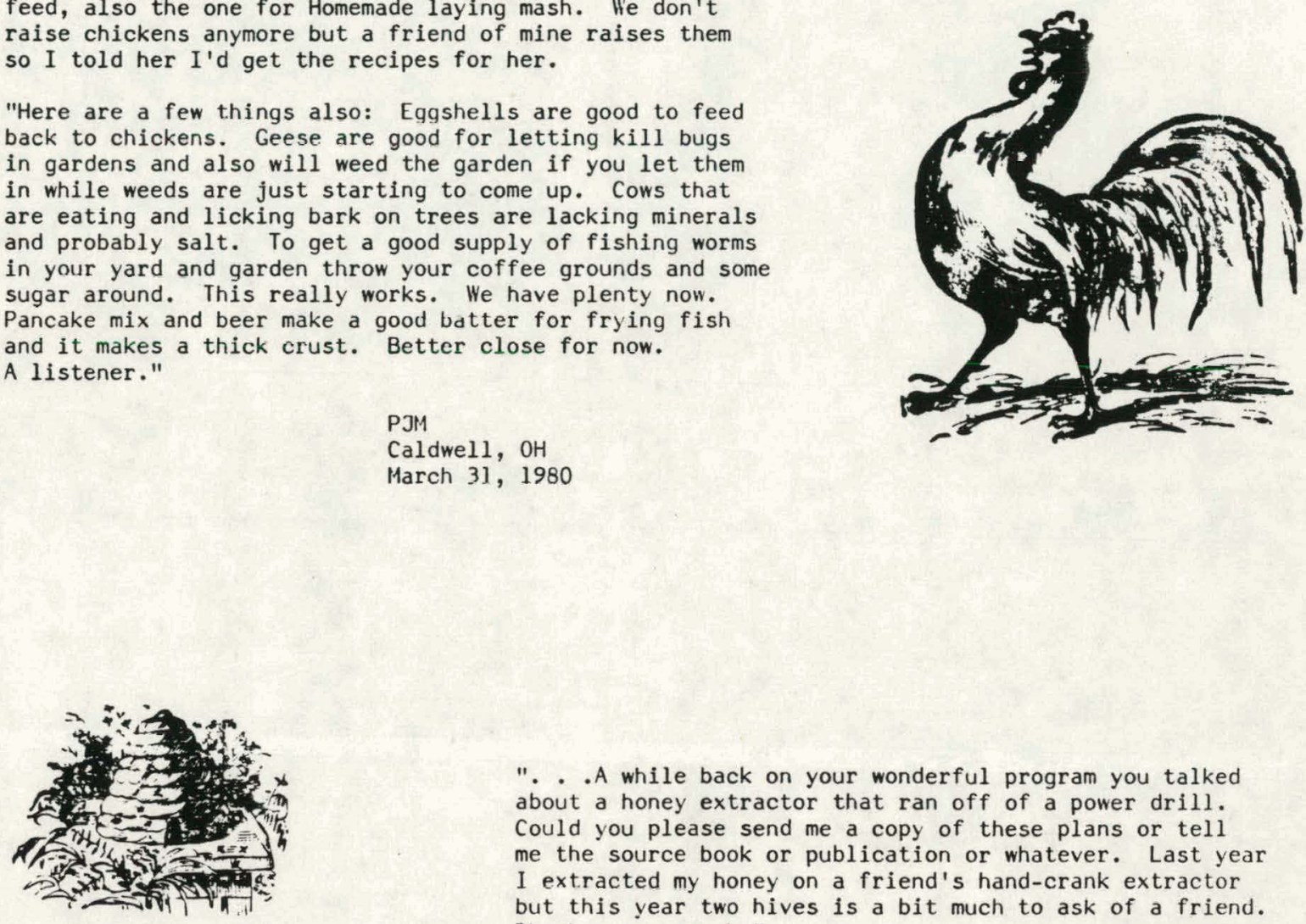

". . A while back on your wonderful program you talked about a honey extractor that ran off of a power drill. Could you please send me a copy of these plans or tell me the source book or publication or whatever. Last year I extracted my honey on a friend's hand-crank extractor but this year two hives is a bit much to ask of a friend. Thank you so much."

PM

LeRoy, w. Va.

Sept. 15, 1980

". . I was wondering if you have or have access to some solar food dryer plans, and if so can I get a copy of them? Also, do you have any info on cooking with dried foods? Any information you can send will be appreciated. Thanks"

CSM

Glouster, $\mathrm{OH}$

September 8, 1978

"Please send me the information you mentioned for passive solar heating do-it-yourself projects, the meaning of the Solar Index, and the material on solar greenhouses. I don't get to listen to your program very often, but I like the kinds of topics you have. Keep it up."

DM

Athens, $\mathrm{OH}$

February 19, 1980 
". . Sorry I haven't had time to call lately, but with Christmas a comin' I'm really busy. I was interested in the "goop" the feller from West Virginia was talking about. A customer came in and I missed the recipe, could you send it please? Also, the other things he had. I missed most of them, too. Keep up the good work. Thanks. .."

EF

Logan, $\mathrm{OH}$

November 21,1979

Dear Bobbi,

I want to tell you about an interesting house just outside of Gallipolis. It was built by Cecil Cook just off the Bob IIcCormick Road. He has built his house back into a hillside and finished the front with logs. So actually he has an underground house combined with a log house. I hear he invites inquiries, but so far we haven't stopped. . .

We are hoping to build a house in the near future. However, like many others I'm sure, money is not that plentiful. So we are looking for the most economical ways of building from a practical standpoint as well as energy-saving and space-saving viewpoints. He plan to live in the basement. and use the main floor for recreating and entertaining. We wonder if an A-frame on top would be the answer if the roof were not sharply angled. Also if we don't go to an A-frame, what materials would make the best and most economical walls? Anyway, whatever good building ideas anyone can come up with would be greatly appreciated. Include in that passive solar heating. I would like to hear a summary of ways in which this can be used, or methods I should say. We would appreciate your pamphlets on Solar Greenhouses and Solar Index. Thanks so much for all your help. Sincerely,

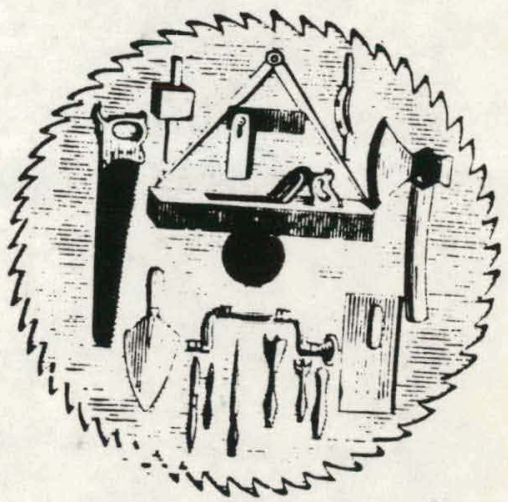

Mrs. JW

Bidwell, $\mathrm{OH}$

January 10, 1980

". . During one of your programs last summer, someone called in about a woodfired hot water heater they had seen in use in Mexico. Have you been able to find out anymore about the availability of wood fired hot water heaters in this country? We'd like to try to incorporate one with a solar system. . ." 
Dear Bobbi:

Un your proyram Loday you were talking about community co-ops and community reliance and that sort of thing. Our family is very much interested in this type of lifestyle. He've had some experience in this type of lifestyle but have just moved to this area and getting connected to a community type situation is somewhat slow-especially during the winter months.

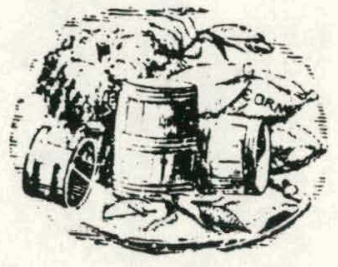

We are interested in sharing our knowledge and expectations of community living and becoming more connected to other people with the same wants and needs.

I would like to help with getting this co-op system working that you were talking about today if I understood it right. Maybe people could write in to you and say waht they would like to contribute-whether it be to share some tools, a skill, or just plain labor work. Please talk more about this type of thing. I really feel strongly about community lifestyle as there are many people in need of some contact with those who care.

Hie are interested in trading our labor in exchange for any type of building supplies such as lumber-used or new-large logs, and such. lie are also interested in learning about honey bees and making honey, co-op gardening, wind and solar energy. My husband does horse-shoeing, welding, and blacksmithing and is

interested in whatever available knowledge on building wood heat stoves and heating systems for home workshop or whatever.

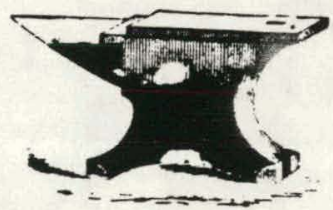

Also, a friend of ours is a chimney sweep in the Logan area and he would also be interested in sharing his skills.

Please get in touch with us if there is any help we can contribute towards a community lifestyle.

Much obliged,

$\mathrm{CB}$

Glouster, $\mathrm{OH}$

February 3, 1978

". . another thing I would like to mention is a spray I use to discourage animals from nibbling on plants.

"This is an organic spray made by adding a couple of tablespoons of tabasco sauce to a gallon of water. It gives the plant a hot taste that discourages them. If you get some on your finger and then accidentally put it in your mouth you can see why. I use this for fruit trees (to discourage deer) and on beans which I had trouble keeping rabbits out of. But I'm sure it will wurk on most anything. You have to spray fairly of ten, like after a few rains and when there is a lot of new growth. . ."

AJ Pinnsboro, W.Va. April 18, 1980 
I would like any and all information you may have on solar energy, solar index, etc. I have built a few solar projects called in on your program once, and I'm very interested in meeting people who are trying to live without outside utilities, electricity, gas, etc. and I might have something to offer them.

\author{
Sincerely, \\ RK \\ Portsmouth, $\mathrm{OH}$ \\ September 5, 1979
}

"We're interested especially in receiving the information for children's solar projects mentioned on Chautauqua this morning.

Thank you."

RG

Athens, $\mathrm{OH}$

September 12, 1979

"Our church group is interested in starting

a co-op. Please send us any information available.

I listen to your program every morning and really

enjoy it."

MB

Shade, $\mathrm{OH}$

November 2, 1979

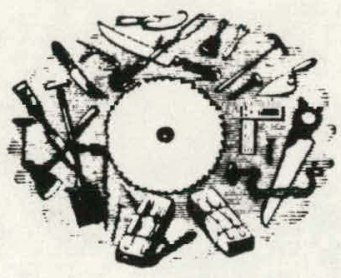

"I listen to your program every day but since 1 ton't have a phone I don'l get a chance to participate.

"I would like to build a composting toilet and a solar food dryer. I would appreciate any information you have on either of these especially plans or a source of plans. Unfortunately, I missed the program where you had a person on talking about composting toilets. .

"I am just finishing my house which is mainly built of cheap or free materials (native and recycled). My $2500 \mathrm{sq}$. tt. house cost about $\$ 3000$.

"I would be glad to help anyone else who is building with whatever information I have.

"I have learned a lot from your program and hope you'll be able to continue providing such a needed service. Sincerely. .."

JH Burnt House, W.Va. September 5, 1979

"I didn't want to call and be on the radio so I'll write and hope you get this before the show on Monday about protein. .

"I love the show-it's like having our own private Mother Earth News and Rodale Press all in one.

I really wish the station would rebroadcast it in the evening-there are so many other people who would like to hear it and don't get to. Thank you." 
"I listen to your show regularly and enjoy it very much.

"In the last year or so you have had several guests who have built or are building underground homes. Some of these guests have extended invitations to your listeners to come and see their homes. My husband and I are seriously considering some kind of underground/passive sular hume construction in the near future and would like to take advantage of your guests' of fers. Could you please send me the names, addresses, and phone numbers of the people you know who would be willing to show their homes so that I could contact them and make arrangements?"

SiN

Murraysville, W.Va.

December 3, 1979

". Mr. McClure was the first caller we heard participating on Chautauqua. Was he the very first? We have enjoyed his contributions. Do hope he was just resting when he said he was in bed. We need his experiences and observations. .."

June 7,1980

"In reference to your show Thursday on cold weather topics: does anyone know about any devices like chains for tires, that can be attached to bools to give more traction on the ice-slick streets to pedestrians? It seems like this could easily be made out of old straps and metal. I saw something like that at the mountain-climbing store, but it was $\$ 10$ and it seems it could be made more cheaply."

JM

Alliens, $\mathrm{OH}$

January 12, 1978

". - I thought I would mention to you that after listening to your interview with the poller, Brian Van Nostrant, I wrote to him and went to visit him and observed a firing of his wood kiln. He also gave me some tips on finding materials to build a kiln. I am an ex-potter who is anxious to yet buck to doing pottery. I really appreciate the fact that you helped me get in touch with him. . ."

AJ Pinnsboro, W.Va.

April 18, 1980 
". . Could you send me the addresses of those underground structures whose builders you featured and of any others you may know of in the region. . ."

PM

April 16, 1979

". . I have a problem right. now and wonder if you know how to help me: My parents will be building a.new house in Maine this year and are planning to build a conventional ranch-type frame. I think it is a shame that they are not incorporating energy saving devices as they will have to use oil or electric to heat. Where can I get plans for passive solar heated homes that would please a conventional home lover? You also mentioned on your March 12th program a pre-fab underground solar-tron home via Mother Earth News. Where can I get this information?

MEB

March 13, 1980

"Would you please send us your free articles on: solar hot water systems, solar greenhouse, solar kiln (to dry lumber), solar homes and heating systems. Thanks so much."

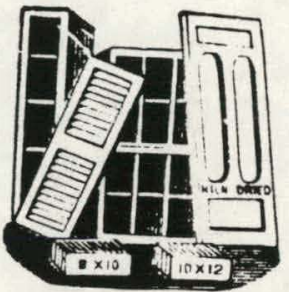

$\mathrm{JA}$

Glouster, $\mathrm{OH}$

January 22, 1980

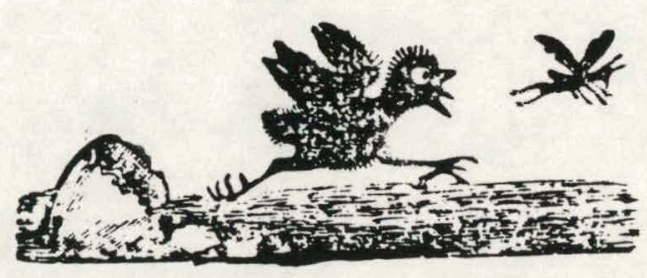

"I hope you can give me some information on food co-ops. I am interested in starting one in Lancaster but I don't know where to begin. Could you give me some names and addresses of people who you might know, that are involved in co-ops, that I may talk with them about starting one? .. Thank you."

TS Lancaster, $\mathrm{UH}$ March 10, 1979

"Could you do a show on extracting oils from nuts of sunflowers, etc. soybeans, and plants? Also, how about a show on goats for the farmstead? We enjoy your show but don't have a phone-how about a write-in show once in awhile."

KW

Palestine, W.Va.

June 1, 1979 
"I would appreciate it if you would send us information on solar greenhouses and also information on food co-ops that you have talked about before. Also would appreciate information on heating with a wood stove. Thanking you very much for your program, and for this information and material."

VP

Chesterhill, $\mathrm{OH}$ January 3, 1980

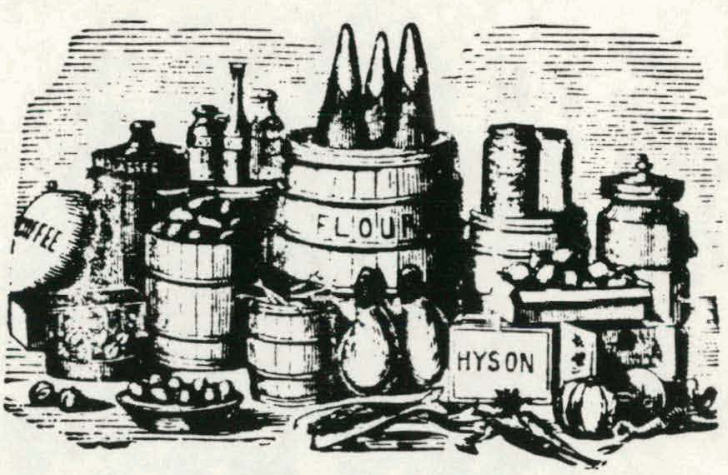

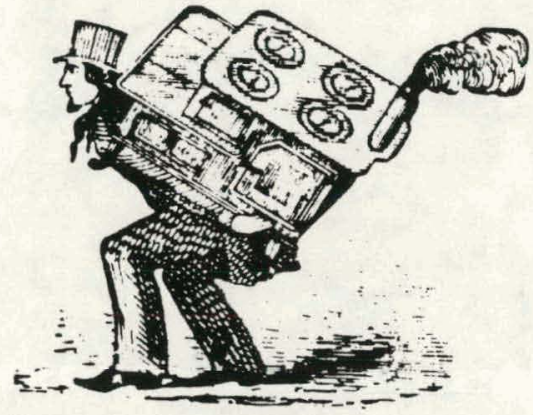

"I really like your program and have since gotten my mother-in-law to listen to you instead of watching Phil Donahue. You have something interesting all the time and I pick up so many new things. I've only been gardening now going on four years and I come from a Florida suburb so country living is new to me but I'm learning all the time. My husband and I hope that someday we'll have ourselves pretty self-sufficient."

\section{GS}

Ravenswood, W.Va.

May 10,1980

". . I would also like to have the information concerning setting up an alcohol still for experimental purposesincluding government regulations and requirements and bonding for the experimental license, etc. Thank you."

$$
\begin{aligned}
& \text { TZ } \\
& \text { Rutland, } \mathrm{OH} \\
& \text { November 25, } 1979
\end{aligned}
$$

"We would like to receive the list of solar publications you mentioned on your program. We really enjoy all the information you provide. Thanks."
RR

Williamston, W.Va. January, 1980

$\mathrm{AB}$

McArthur, $\mathrm{OH}$

October 11, 1979 
"There was a man on your program who had built a solar house. We are turning our carport into a family room and am wondering if there is anything we can do to help heat it with the sun. Would you please give me his name and phone number? I think he said it was o.k. to see what they had done with the solar house he built. Thank you."

$\mathrm{PC}$
Pomeroy, $\mathrm{OH}$

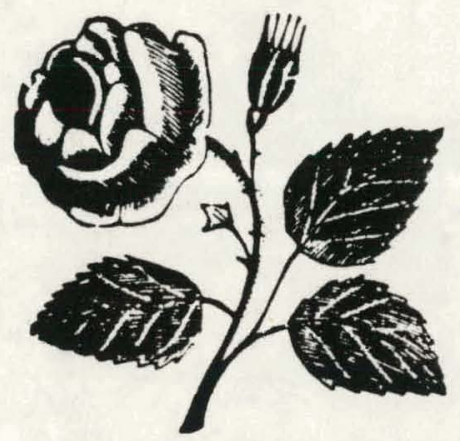

Dear Bobbi,

Just wanted to let you know how much we appreciated the "Mrs. Higgins Show." He, ourselves, have just become involved in "goating" this spring and she has been of invaluable aid to us in our endeavors. Goats are tricky little creatures and require some knowhow in the raising thereof. She certainly has that knowhow.

I was wondering if it would be possible for you to have her on a regular basis-say once a month or every two months for those in the listening area who can't pick up a phone and dial her direct; those listeners in W. Va. and out of our area.

We are finding more and more goat people as we become more involved in the enterprise. We may be an esoteric group, but are not necessarily a small group.

I myself don't have a phone but if Mrs. Higgins were to be on a regular basis I would surely have a list of questions to send in for you to choose from. I know there were alot of questions we've had in considering and contemplating goats that weren't covered Honday. Most of the questions were from people already into goats-I would like to send in some questions relative to going into goats while they are still fresh in my mind.

Anyway - thanks again for the "Mrs. Higgins Show;" she's got to be Southeastern Ohio's first lady of goating. Regards.

KG

Athens, $\mathrm{OH}$

May 13, 1979

". . I really enjoy your talk shows! In a time of growing inflation and poorly made merchandise it's truly a breath of fresh air to hear people trying to help themselves and others as well.

"I am now trying with little success to learn how to quilt. Most of the information I have found is for those who already know how. Any information you or your listeners could yive me hüuld be appreciated. Keep up the good work." 

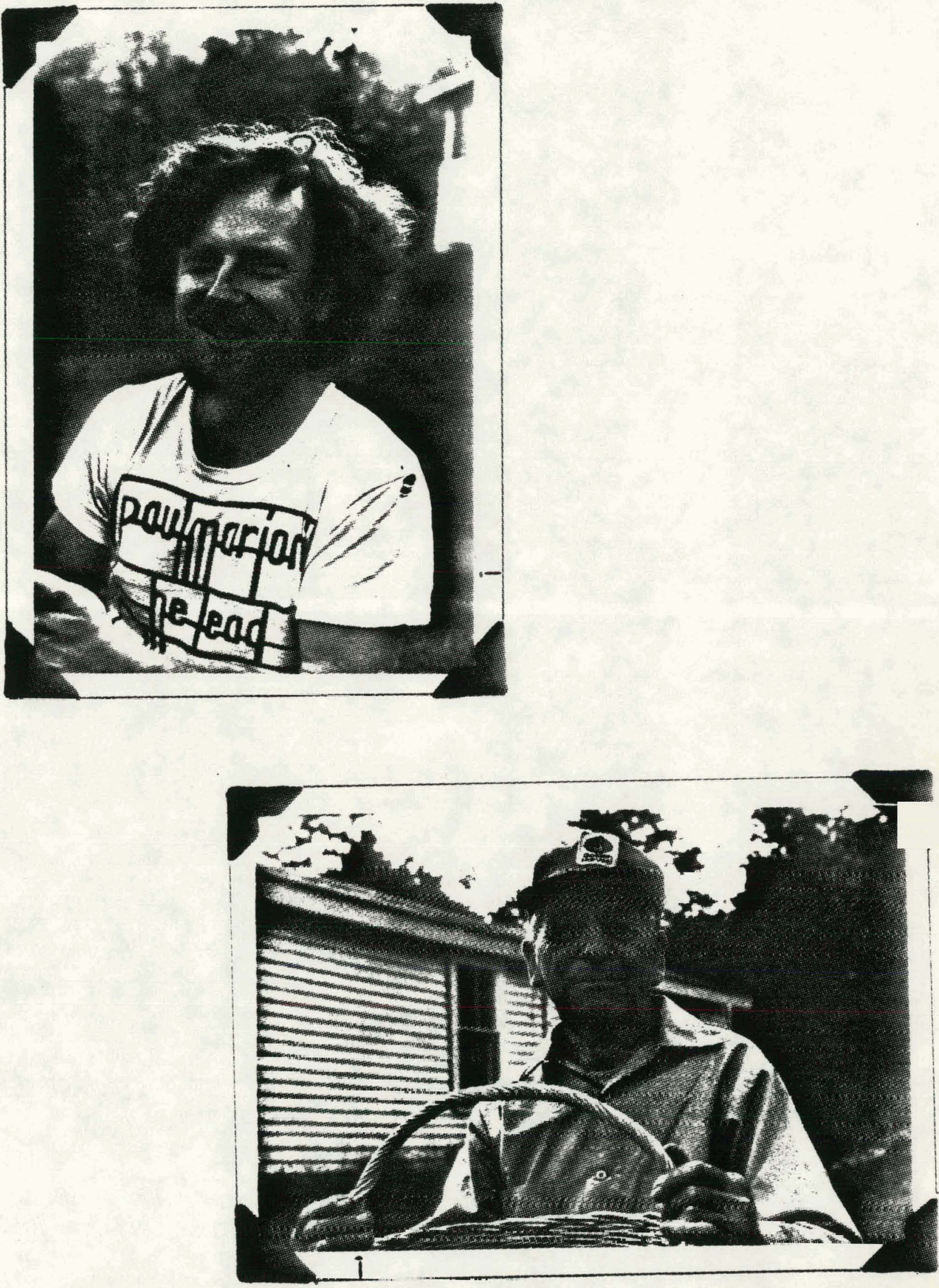

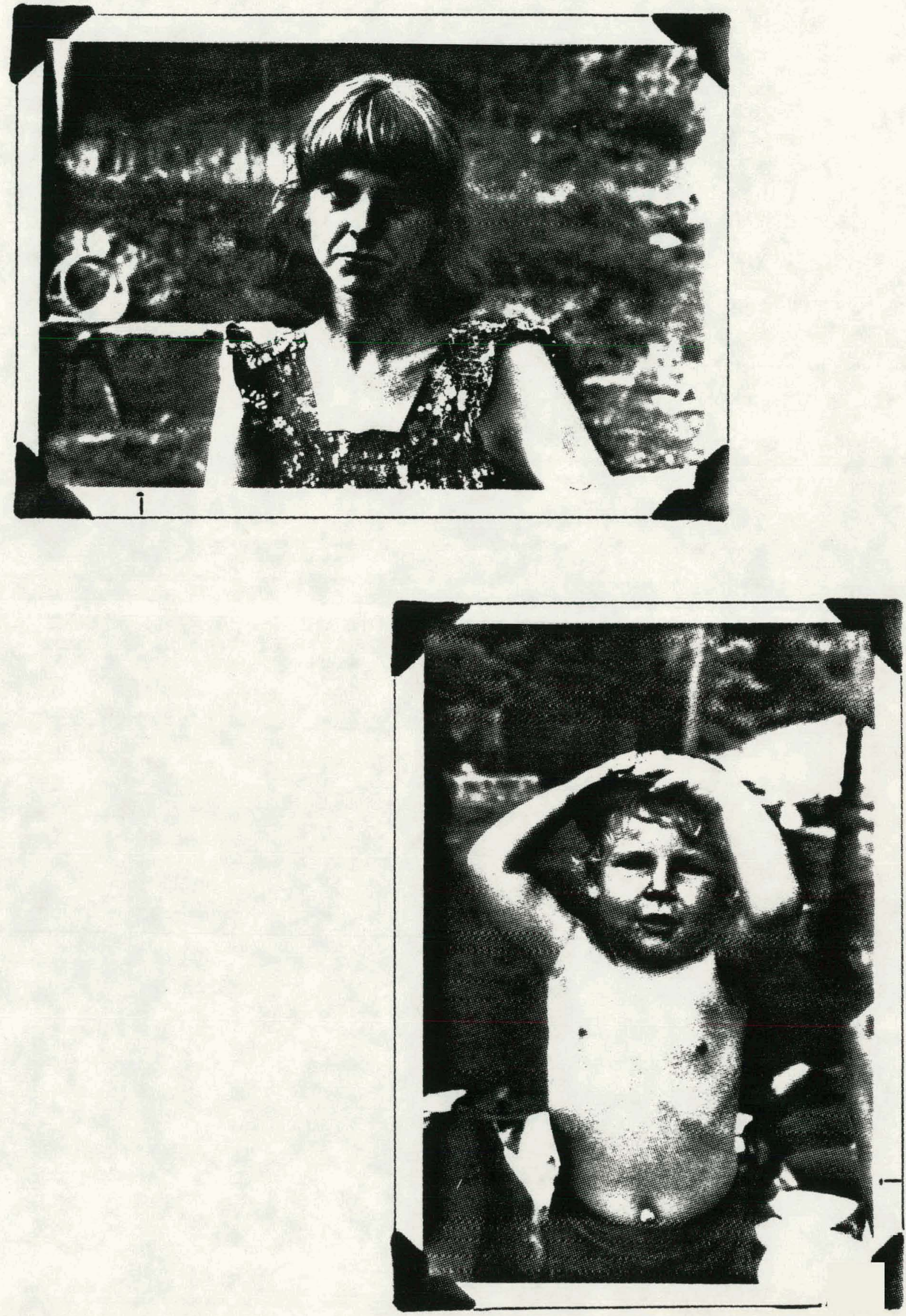


\section{Program Features}


Naturally, I'm an advocate of live radio programs. There's much to be said in favor of the spontaneity of such programs. And, of course, a call-in show has got to be live in order for listeners to participate. Nonetheless, even in a live call-in information-exchange like Chautauqua, there's a place for pre-recorded (or taped) informational segments.

Short, pre-recorded features might be used to get the ball rolling in the beginning of a show, or they might be used to fill out an empty spot on those rare occasions when there's a problem with the phone lines. At any rate, pre-recorded material can be an invaluable resource.

One of the recorded segments heard each Friday during Chautauqua (and again on Saturday morning on WOUB-FM) is a locally-produced feature called "Kidpower." "Kidpower" was conceived as a way for kids in Southeastern Ohio and West Virginia to express their views on energy or energy-related matters. Since the shortage of non-renewable energy will affect future generations (including today's kids) it seems likely that they might have ideas, commentaries, inventions, stories, or conservation tips to share.

By working through area schools, teachers, Girl Scouts, Boy Scouts, etc., I've gotten in touch with dozens of school-aged kids who have galuable, imaginative, and often amusing ideas about our energy future.

Once I hear about a kid who might want to be on "Kidpower," I call her or him and explain the program. We then arrange 
a time later that week, or the next week, to actually record their energy thoughts, inventions, poems, etc. I always try to give each kid a week or more to write their story or organize their thoughts for the show.

Then, on the appointed day, I call and record the short (5-10 minute) feature over the phone. Since our broadcast region covers 32 counties of Ohio and West Virginia, I prefer to make use of the telephone for recording this show rather than expect kids to travel up to 65 miles to the studio.

"Kidpower" has proved to be a success not only with Chautauqua 1 isteners of all ages, but with participating kids and teachers. Being on the radio seems to give an extra incentive for giving some thought to the matters of energy.

There are any number of possible local features which could become interesting additions to a live call-in show. Several ideas for locally-recorded segments might be:

1) A weekly recorded feature on the best listener recycling idea in which the listener explains how she or he recycled something or cleverly reworked some material into longer use, etc.

2) For an areas of the country where wood heat is in widespread use, a weekly 5 to 10 minute feature concerning the safe use of wood stoves; the efficiency of various species of wood; chimney sweeping tips, etc. Choose knowledgeable wood-heat persons in your area to call or invite them to come in and record these features for broadcast during the heating season. 
3) A weekly feature/report on low-cost alternative energy ideas which provides practical information from area residents who use passive solar or who have developed for themselves some alternative energy for heating, cooling, drying clothes, heating water, drying food, etc.

4) A series of features during the growing and harvesting season on such thiggs as your area's farmers' markets; the best gardening tip of the week; energy-efficient non-chemical bug-control tips; or canning, freezing, food drying, and other tips on preserving. Record these features over the phone with a different person each week.

5) During the winter months you could record weekly tips for keeping warm and reducing energy consumption while during the summer months you could concentrate on energy-efficient tips for keeping cool. Find listeners who would record these tips regularly.

There are hundreds of other possibilities for incorporating some recorded features into a live, appropriate technology information-exchange. Probably the most important thing to keep in mind is to encourage your listeners and area people to share information during these short features and be sure to keep them lively, instead of impersonal and academic.

of course, in addition to producing your own features, you can also use other pre-recorded or pre-packaged material. There are quite a number of places to find interesting taped features on appropriate technology topics which might work well in a regional call-in program. 
For example, most all Public Radio Stations carry National Public Radio's (NPR) news show, All Things Considered. Many stations routinely record the show and broadcast it later in the day. This lively news program often has outstanding features or commentaries on appropriate technology and energy-related topics which I record for use on upcoming Chautauqua shows.

If, for example, All Things Considered broadcasts a short feature about a wind-generator on top of an apartment building in New York City, I may re-air this feature during a windpower program on Chautauqua in order to offer a different perspective on windpower.

Before using this type material, however, be sure to check the terms of broadcast rights your Public Radio station has with NPR or other networks or suppliers of broadcast material. Some material may have a stipulation for live broadcast only, or only once, or only within a month of the original broadcast, etc.

There are quite a few other short, pre-recorded features on appropriate technology which you might consider using. Many of these features are free to Public Stations, so if your station isn't already receiving them you might investigate the possibilities of getting hold of them.

Here are just a few of the available features which you might consider using from time to time:

All Things Considered from National Public Radio

"Organic Times" from:

Cinema/Sound Limited

311 West 75 th Street

New York, New York 10023 
Mother Earth News Radio Network P.O. Box 70

Hendersonville, N.C. 28739

Agricultural Reports from your state's Department of Agriculture or the U.S. Department of Agriculture

Reports from your County Extension Office on food growing, harvesting, and preservation.

"Waste Not"

The National Center for Resource Recovery

1211 Connecticut Avenue, N.W.

Washington, D.C. 20036

Various Public Service Announcements (PSA) on recycling, solar energy, conservation, etc.
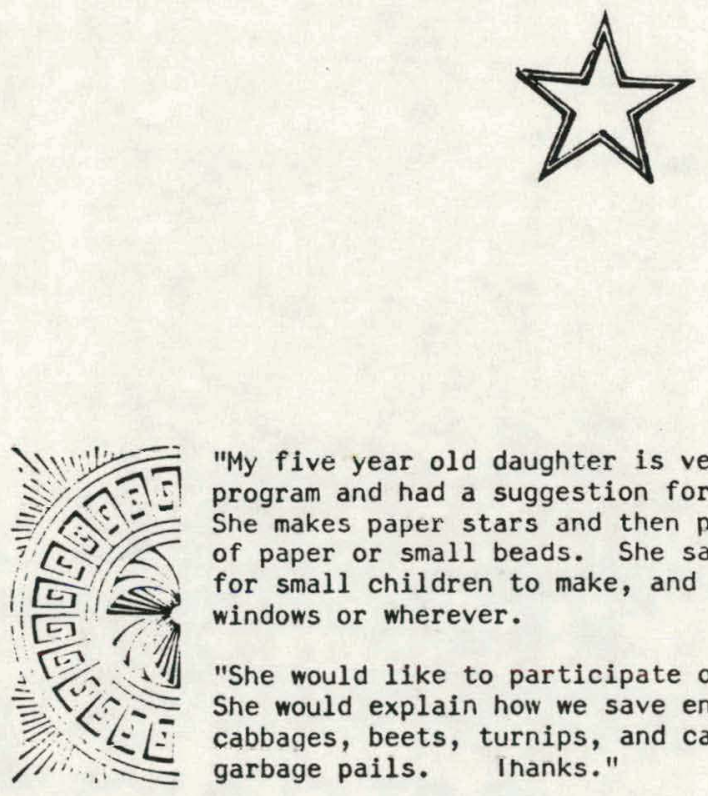

"My five year old daughter is very interested in the program and had a suggestion for season's decorations. She makes paper stars and then pastes on colored bits of paper or small beads. She says they are very easy for small children to make, and can be hung up in windows or wherever.

"She would like to participate on "Kidpower" also. She would explain how we save energy by burying our cabbages, beets, turnips, and carrots outside in garbage pails. Ihanks."

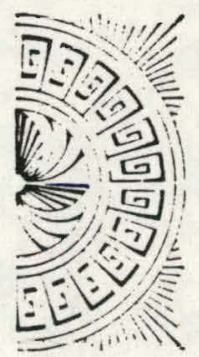

SS

Reader, w.Va.

December 20, 1979 


\section{Coming 0 age in he 80's}

\section{Kidpower}

A new generation will cunie of uyi in the 1980 's. To a large extent, decisions made decades before will shape their world; then it will be their turn to take up the reins of what has seemed for years a runaway horse.

Because this generation will inherit the 80 's, A.T. Times thought it appropriate to give them A.T. Times thought is aproprafficult to find we found a part of the new generation that is not content to sit back and wait for their "coming of age." I hey are grammar selivul siudents featured on

"Kidpower," a children's radiu shiúw produced in Athens, Ohio.

"Kidpower is a weekly feature of

"Chaulaurun " a local radio call-in shnw that features self-reliance and appropriate

technology "Kidpower" airs for five to ten

minutes on Friday and Saturday mornings over WOUB $1 \mathrm{M}$. The kuds are inuited to present their ideas on the show after a screening by "Chautauqua" host Bobbi Renz.

The kids definitely have ideas - from Jason Gray's rigging a piano to produce electricity to an 11 -year old who powers the uveritiead light in his bedroom from a miniature windmill outside his window. Renz reports the children often write in with inventions.

Beyond the mechanics and the tools of energy and appropriate technology, the kids have opinions on energy policy. Give a listen...

I want to tell you about our underground house. Don't get the idea that it's completely underground. The front isn't underground. Just the other parts. It's kind of built into the side of a hill.

' oner pars. lis The reason it's underground is because it's energyefficient. Under a cert , degrees or so. So you can see why that helps. Imagine it's like zero degrees outside; then it's 50 underground, so then all you have to heat up to is maybe 20 degrees or whatever you like.

We're planning to cut down on all that oil and gas and tell OPEC who's who by heating our home with and the earth's heat.

About the solar part of it all, I didn't exactly mean we're going to have giant solar things. The sun's simply going to shine through our windows on our southeastern side. That's the side you get the most sun, I think. When the sun shinies in through the vinntrus the sun's heat gets trapped and it stays in.

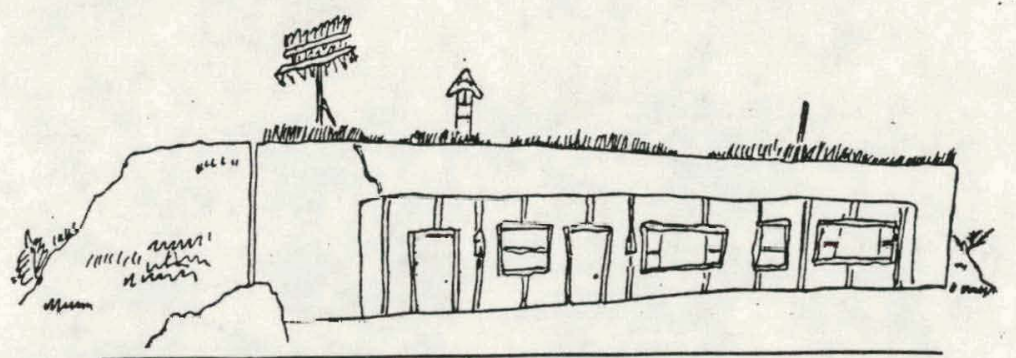

I have this invention that runs a generator on electrical energy by playing the piano...

Each key, or to be conservative, every other key has a string aftached to it so when you push the key down the string comes down. The string will be on the outside of the keys and go through little holes drilled in the piano and they'll pull down on a wheel.

The gizmo underneath each of the keys, a sor of spool winder, should be connected to the keys so that when you push the key down the bunch of gears activate the spool winder and pull the string faut again.

Each turning wheel would have the shaft attached to it and the shaft would be connected to an electrical generator and when the shaft was turned, the electrical generator and when the shaft was turned,

generator wnuld produce electrical energy.

Kind of a simple idea - you could elaborate on it. You could adapt it for other things, like organs and typewriters, things like that. You couldn't make too
much energy from it, but if you got some kind of

"Kidpower" guest David Gagliano, 14, of Athens explains how his homemade solar recycled materials, with the back from an old "Chautauqua" program, the kids' show temperature always stays like 50 degrees, so you can imagine in the summer it's nice and cool in our imagine in the sum our house, In the spring we're going to throw some hands. I mean, not mess up Mother Nature or anything, but just take what's around us. When I'm more wind power, even some tidal power houses and building being put up, so we kids can have some energy left for us, too.

Robert Bowman

Age 12

Athens, Ohio turn on a light.

You ever hear somebody play the piano in a big auditorium's lights and the lights would be out and fast.

You coult get a set of colored lights and have each key activate different lights. You could have five key activate different lights. You could have five different generators on the piano, each

connected up to a different kind of light. holes in it and set an electrical generator in it.

Jason Ciray

Age 11

Ames, Ohio

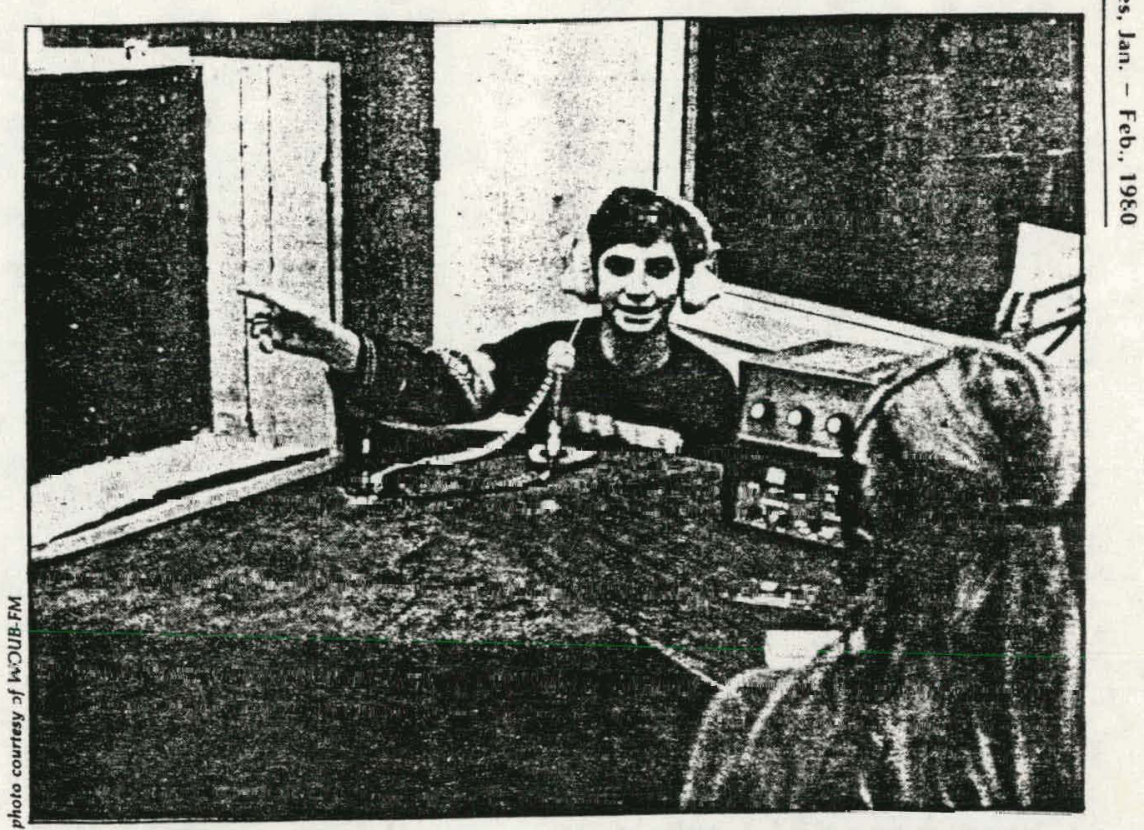
water heater works to talk show host Bobbi Renz. David's water heater is made largely of gun rack and coils from an old refrigerator.

reaches a 32-county area in Ohio and West Virgina. "Chautauqua" was chosen by the Ohio Education Broadcasting Commission in 1979 as the outstanding community service program in Ohio public broadcasting. NCA and the Tri-County Community Action Agency of Atheñs are sponsors of the program.

Not only does it stay toasty warm in the winter, in the summer it stays cool. As I told you before, the earth's

We have almost exactly, I think, two feet of earth on grass on top of our roof and we may even grow some flowers, so we'll have to think about mowing our roof. You may ask why we're doing this thing, but I think we ought to start taking energy around us into our ow older I wish to see more underground, more solar, and

special generator you could produce enough to, say, auditorium? You could hook the generator up to the when the piano player starts playing the lights would on, depending on how loud she was playing and how set your mind to it, you could do it. We have a piano, but I don't know if my mom would allow me to drill

\section{Energy Poem}

These things you do for you and me Will save us lots of energy.

You do these things to save our land So our life will be so grand.

Turn out that light,

And flick that switch

And don't wash your clothes until you itch.

Take a shower very fast

So our energy will last.

Burn your wood so you'll be cozy

And the rest of your life will be rosy.

Ride your bike to work or schoo

Then you unn't he a fuelish fool

If we work together in all kinds of ways,

We'll save energy the rest of our days.

Molly Morgan

Age 10

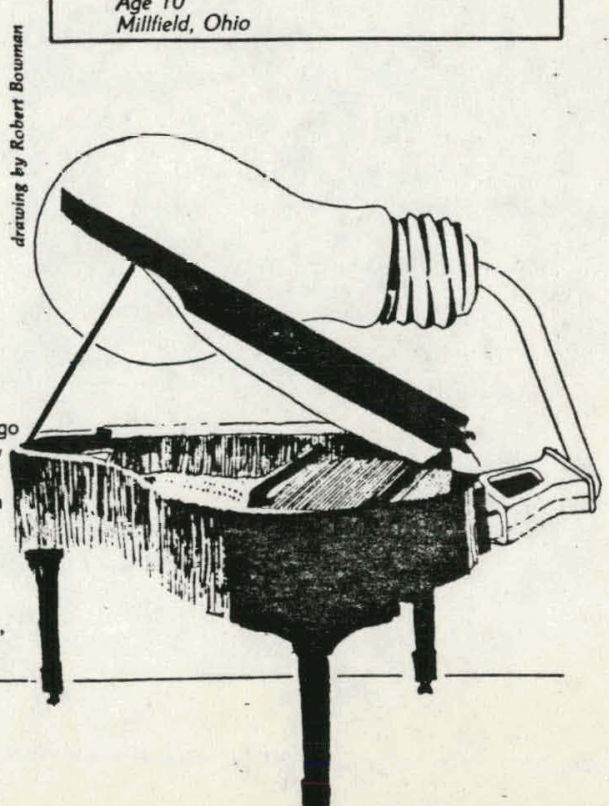




\section{Finding Help}




\section{FINDING HELP}

Although producing and hosting your own appropriate technology call-in show is something that one person can handle, it's always nice to have a little help.

I'm a real believer in the idea that two heads are better than one. I also feel that everyone has something to give and that most are delighted to help out if asked.

If you have a local university nearby, you may be able to find interested students enrolled in ecology, engineering, mechanics, or geography classes who have an interest in the program and who may be able to work on a regular basis as part of an "internship." In some cases, university students may be able to receive some academic "independent study" credit from a professor who sees the value of learning to use the media. There are all kinds of possibilities here.

As part of a course project, broadcast students may be able to help you produce short 30 or 60 -second promotional spots to be aired at other times of the broadcast day. Or, they may be able to help you record your special pre-recorded weekly features on woodheat, appropriate technology, or gardening tips.

Advertising students may be able to write some news releases or otherwise help you publicize the show. And geography students may be able to do some in-depth research on a particular topic for your region. They may also be able to line up a series of special programs on specific topics. 
Students are always looking for ways to make their educational experience more practical, and by working with your program, they'11 be learning something not only about appropriate technology, but about radio production :as well.

And when it comes to helping with "Kidpower," I've found grade-school kids to be thoroughly enthusiastic about dreaming up stories (complete with sound effects), poems, inventions, and commentaries.

I've also found senior citizens to be especially helpful in digging up hard-to-find information for the Chautauqua program. They have been only too happy to pitch in and help with the overall show.

So when it comes to getting a little help, don't be afraid to ask. You'11. more than likely find, as I have, that most people are delighted to give of their enthusiasm, time, and energy. 


\section{Promotion\&ePublicity}


In an effort to attract listeners to a call-in show, it's important to promote the show not only on the air, but in print in your area newspapers, newsletters, and magazines.

Several weeks before beginning the new call-in show in your area, you should begin promoting the show so that people will not only know about it, but will tune in, and hopefully participate.

When I began the Chautauqua show in Southeastern Ohio, I went to area newspaper publishers with a short article I had written describing what type of show it was, the topics to be covered, the time of day, the station, etc. All of the newspapers were more than willing to print the articles the day preceeding the first broadcast of Chautauqua.

A1so, several weeks before Chautauqua began, I produced a 60-second promotional announcement ("promo") telling about "the new call-in show to begin on November 7 th, etc., etc..."

Don't assume that people will simply stumble onto your show. If they don't know that it exists, you've got to tell them about it. Unfortunately, some people may have never, even 1 istened to your radio station before. Or, if they do listen, they may never listen at the time your show happens to be on the air. So you've got to reach them in as many ways as you can to let them know that "appropriate technology is alive and well and broadcast each day (or each week) on Public Radio Station . Don't forget to contact local food co-ops, churches, and consumer and environmental groups; they have newsletters and bulletin boards that will help to spread the word. 
Be sure not to let your promotional efforts die after the first weeks of the show. Follow through with more print and on-air promotion for any special show or series of shows which are planned several weeks in advance. I've found most newspapers will run an article on special Chautauqua shows like a three-day special on woodheat, two days of passive-solar-house designs, or a special interview with some well-known guest such as author Ruth Stout, etc. They'11 run these articles free of charge because they're a service to the public. However, if you're sending them copy to run every day, they may be somewhat hesitant to use it unless they have a regular column like "What's Happening On Local Radio" or something to that effect. For best results, try to keep your press releases fairly short and to the point.

It's also important to keep up with regular on-air promotion at your own Public Radio Station. Be sure to let the morning, afternoon, and evening announcers at your station know what's on your show each day so that they can give live promotional announcements of upcoming shows.

And don't forget to publicize upcoming features and topics on your own show. At the end of each Chautauqua, I try to promote the next day's program and any other upcoming special programs to be heard during the next week.

Getting out into the community or region at energy fairs, county faire, group meetings, etc. is also a great way to promote the show. I have fond memories (and some great recorded interviews) from a regional senior citizen meeting I attended. After giving a brief impromptu talk about Chautauqua, I got some of my best ideas for upcoming shows from that audience. I also recorded 
some delightful recollections of heating with wood and "simple living." And the senior citizens seemed to have as much fun as I did.

Never overlook an opportunity for letting others know about your program. After all, the more you expand your audience, the more successful the program will be.

Although publicity is an ongoing process, it needn't be an unpleasant one. Sometimes, publicity and promotion will give you a chance to branch out and try new things that you might otherwise be hesitant to try on the show. For example, in writing and producing promos for the show, I often delve into all sorts of fun creative endeavors which I otherwise wouldn't try. There's no limit to the realm of creativity that can be experienced. Like songwriting for example.

Although I don't have the talent or background in music necessary for any songwriting which could be taken seriously, I do have a desire to put words to music. So, when producing a promo for "Kidpower," I decided to put the words describing "Kidpower" to music. I wrote a few lines and by working with an area music teacher, was able to put them to music. We arranged to have a local school choir sing and record this little dittie, and voila. . a promo and theme song for "Kidpower." It was great fun for me, the music teacher, and the kids in the choir, and has served as an appropriate theme for the show.

When it comes to publicity, the sky's the limit. Be sure to take full advantage of all the opportunities which present themselves when it comes to promoting your show.

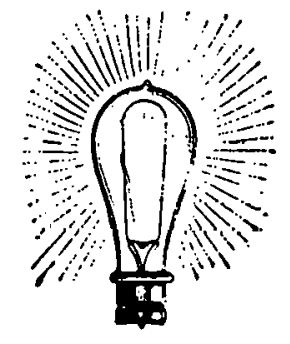




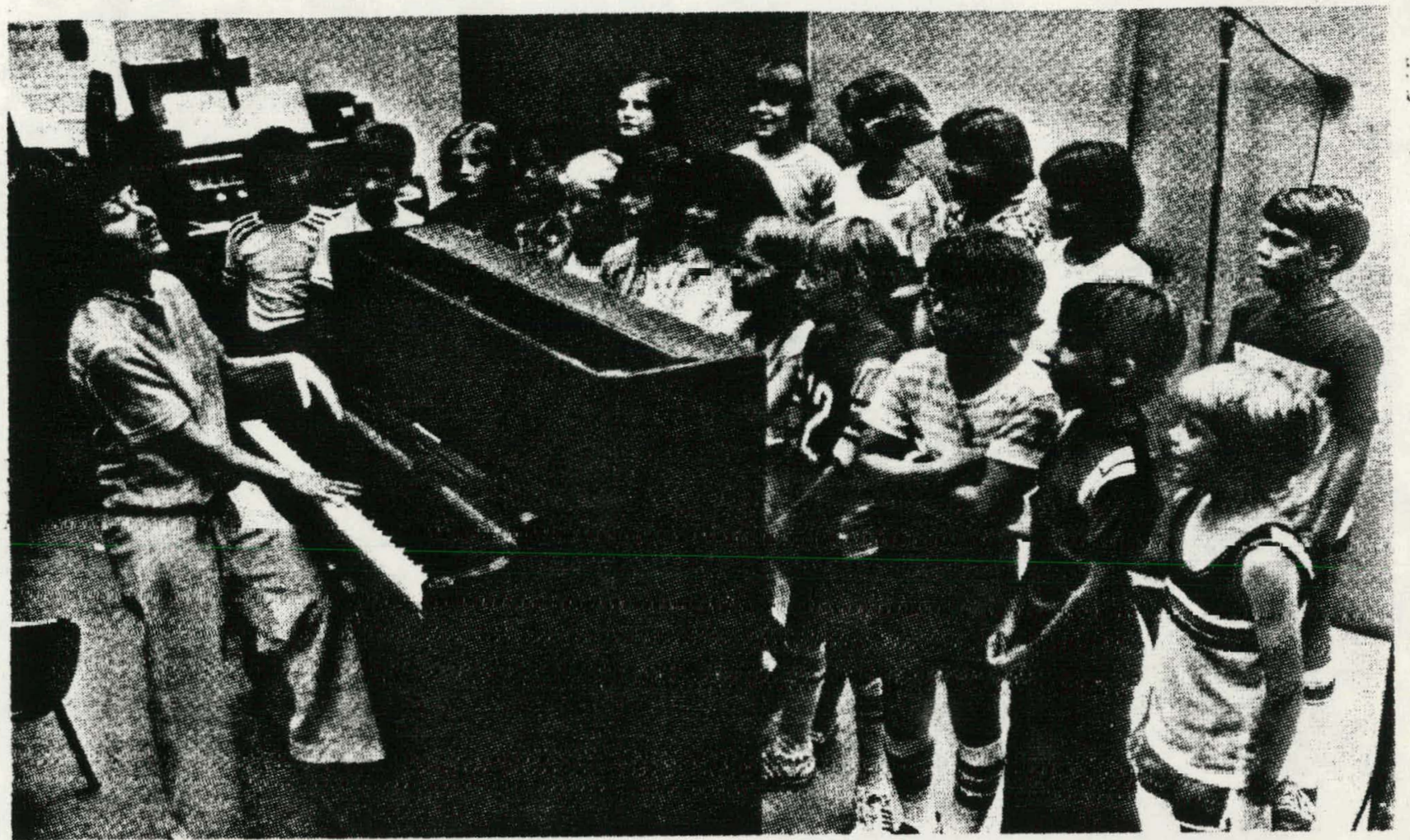

THEME SONG RECORDED - The Athens Morrison Elementary Chorale is shown reconding the theme "Save Me a Little Energy," for the new "Chautauqua" segment "Kidpower," which will begin at 9:55 a.m. Friday and be heard each Friday on WOUB radio. Accompanying the chorale is
Morrison music leader Nancy Burson. Children from the WOUB listening area will be invited to share their ideas on saving energy for the segment, according to producer Bobbi Renz.

\section{Changes, Program Ready at WOUB}

Beginning Friday, kids from 30 counties of Southeastern Ohio and western West Virginia will have an opportunity to share their views and suggestions concerning energy on the new WOUB program "Kidpower." Produced by Bobbi Renz. "Kidpower" will be heard at 9:55 a.m. each Friday motning during "Chautauqua."

School-aged children from
the area will be sharing their
thoughts on energy conserva-
tion, energy inventions, stories,
poems. recycling ideas and
ways of having fun without
using energy. The first "Kid-
power" show will feature 12-
year-old Jason Grey of
Amesville telling about his
energy invention which

produces "electricity" from playing a piano.

Area kids interested in appearing on the radio program "Kidpower" may send their written energy ideas to: "Kidpower," WOUB Radio. Athens, OH 45701. 


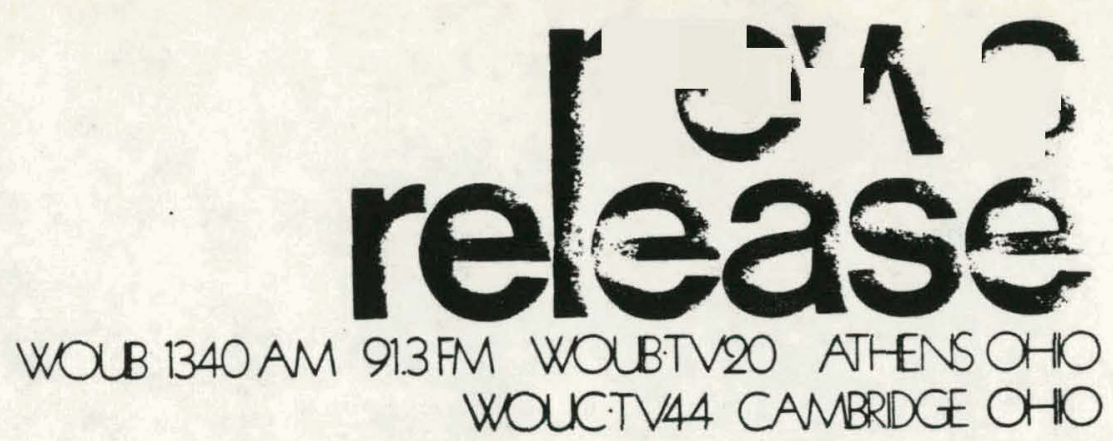

FOR IMMEDIATE RELEASE

CHAUTAUQUA ON RADIO

October 21, 1977

Do you remember the Chautauqua? The term is new to many, but refers to

traveling tent shows popular in the late 19th century and early 20th century.

Prior to the advent of mass medla, Chautauquas were, for many people,

rare opportunity to leam about different places, people and customs, to

share Ideas and know-how and to be entertained.

Applying the concept to radio, WOUB FMgl will begin a new call-in talk

show called CHAUTAUQUA on Monday, Novenber 7 at 9 a.m. The call-in phone

number is 614-594-5544.

Hosted by Bobbl Renz, the show will air Monday through Friday and will feature regular interviews and eall-in comments from listeners. The central theme of CHAUTAUQUA is "country IIving" and initial copics of discussion will include: gardening, litemative energy systems, ralsing livestock, beekeeping, logging timber and dam-home cooking.

Late In Hovember a week-long energy special will feature: weatherizing and winterizing homes and apartments; how greenhouses can help heat homes all winter; the variety and efficiency of rood and coal stoves, and how to utillize the sun's heat without collectors or expensive equipment.

HOUB's CHAUTAUQUA wIII provide an opportunity for erchanging Ideas and experiences with people throughout the region. If you have any suggestions for toples or guests for the show, drop Bobbl postcard at HOUB, Athens, Ohlo 45701. LIsteners are invited to call and particlpate with questions or comments during the broadcasts. The CHAUTAUOUA phone number is 614-594-5544. 


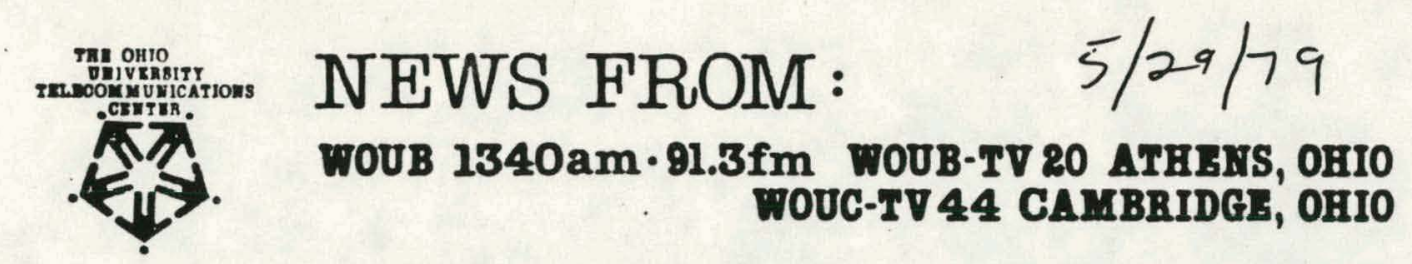

"Chaltainua" extands TO ONE HOUR

FOR IRTTIIATE RELEASE

CONTACT:INATEARET

POInSFP.

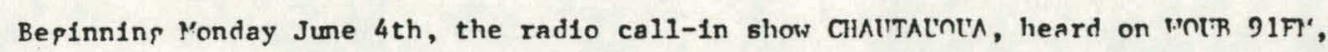
expands to one-hour each weekclay morning bepinning at 9:05am. ('reviouslv a half-hour propram). The propram CIAUTALQUA was recently awaried funds for expansion from the Nationa] Center for Appropriate Technology and Tri County Comunity Action Apencv.

In addition to the increase in broadcast time, the propram will be takins on some other new characteristics (or features). The "Solar Index" report w11] he men daily mid-wny thru chinutauqua as en indication of potentiaj solar enerpy in the area. The "Solar Index" is a nationwide service proviced to radio and television stations by the Department of Fnergy in conjunction with local veather hureaus. Currently the Columbus weather bureau supplies "Solar Index" Information to InI'B refjecting the dally solar energy avallable in the Columbus, nhio area. (nther weather bureaus In the Wni'B broadcast repion are expected to participate in this service in the future in an effort to broaien the "Solar Index" reporting gervice). The "Solar Index" Indicates the amount of solar enerpy avallahle for use in a domestic solar hot water heater.

nther elements of expansion to be heard on CHALTAUnil include frequent intervievs with locnl people on a wide variety of topics. Fimis have heen maile avallahle to Include frenuent long-distant phone interviews with mests in other ports of the Infted $S$ tates in an effort to expose listeners in Southesst Chio and Vest Virsinia to Information shout appropriate technolopv not reailly avaljabje localjv. As alwavs, collect calls vill be accepted from anywliete in the "nip $F$ ' brnariast repton curing Chattalnua ( 9:05-10 am each weet day). The coljert cirattainita nhone number is:

f14-594-5544. 


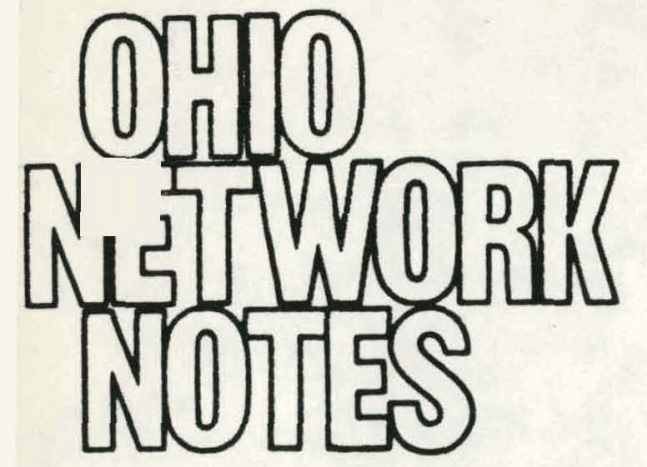

\section{Oebie Awards Highlight Meeting}

WGTE-TV, Toledo, and WGUC-FM, Cincinnati, were big winners in the 1979 Ohio Educational Broadcasting Awards competition presented June 11 in Bowling Green.

The Toledo station accepted Oebies in both the Public Information and Development categories with its "Vibrations in Black" awareness campaign and Studio Club Membership drive respectively, while WGUC-FM claimed honors in the same categories with its "Show Off ' 78 " awareness campaign and fundraising marathon.

WOUB-FM, Athens, won an Oebie for its "Chautauqua" series in the Cornmunity Service category plus an Oebie for its producer'host, Bobbi Renz.

Other individual winners were lanet Tadlock, instructional television coordinator for the Ohio ETV Network, in the Outstanding Contribution to State System category; Bette Wallach, former administrative assistant to the director of the Network Commission, serving in that capacity from the Network's inception in 1962 until her retirement in March of this year, a special Commissioners' Award; and Dr. Martin Essex, former state superintendent of public instruction, and Dr. John Millett, former chancellor of the Ohio Board of Regents, both former statutory members of the Ohio ETV Network Commission, who shared the prestigious Commissioners' Award.

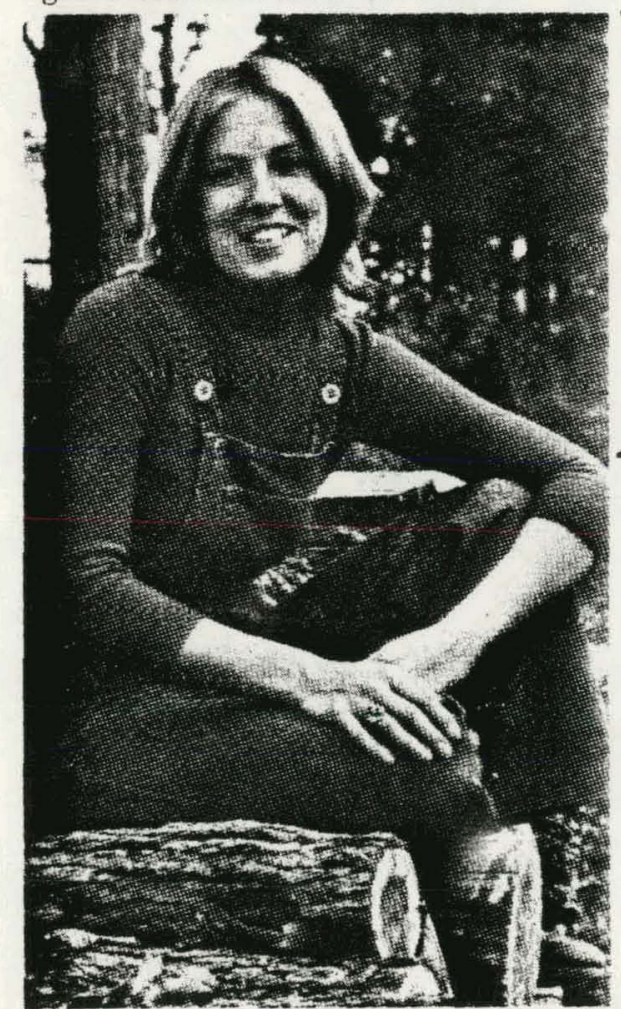

Bobbi Renz
Channel 30's "Vibrations in Black" awareness campaign was judged superior in meeting its objective in increasing awareness of public television in Toledo within the black community$13 \%$ of the city's total population. The campaign also was chosen as the "most outstanding example of public awareness" by the Corporation for Public Broadcasting in its 1978 Public Television Awards competition.

Judges also commended the station's Studio Club Membership drive which was held to develop a new membership category for those who can afford to make large annual contributions to the station.

WGUC's "Show Off ' 78 " was honored for its success in achieving its twopronged goal: to increase awareness of the station through on-air promotion, news releases, public service announcements on other radio and TV stations, posters, marquees, buttons, flyers, etc., and to increase contributions to the station. An increase from $\$ 75,906$ the year before, with identical fundraising techniques, to $\$ 102,308$, was attributed to the increased promotion efforts.

"Chautauqua," a radio call-in program conceived, produced and hosted by WOUB's Radio Traffic Manager Bobbi Renz, was chosen by the judges for its success in providing the people of Southeastern Ohio and West Virginia a forum to do something about the pressing demands of inflation by sharing information on topics related to self reliance, such as alternative energy, food preservation, home repairs and gardening.

Ms. Renz developed and carried out the concept on a voluntary basis above and beyond her full-time duties as traffic manager for the two radio stations (WOUB AM-FM). She has since successfully proposed a grant from the National Center for Appropriate Technology for $\$ 36,000$ which permits her to become a full-time producer/host for "Chautauqua." The grant also provides for longdistance collect calls from listeners, two part-time assistants and allows the 30 minute format to expand to a full hour each weekday morning.

Ms. Tadlock was honored for her success in maintaining an efficient distribution schedule of instructional television programs from the Network to the 12 educational television stations in Ohio since the interconnection system began in September 1975. In-school programming consumes the butk of each station's Monday through Friday schedule with

(Continued on Page 3) 
Technical/Engineering 


\section{TECHNICAL/ENGINEERING}

One day in 1975 while I was typing away as a "traffic manager" at a small commercial radio station in Southeast Ohio, the station owner said, in a panic, "Our morning-man and call-in host just quit on-the-spot, effective immediately!!! Any chance you (who have never been behind a microphone in your life) could do this show starting tomorrow morning at 9 o'clock?"

With no previous experience and never having voiced any desire to be on the air, I was an unlikely person to take over this morning slot. But as luck would have it, this station had a limited staff and everyone else had already been railroaded into some extra on-air responsibilities. So, with very little consideration on my part, on a lark I said, "Sure, I'11 host the show. Can you find someone to give me a quick lesson in engineering the show this evening?"

And so, I began with an hour-long crash course in radio broadcasting. And those first few days, although a little choppy, weren't half bad.

Since that time, I've gradually been picking up any.. "engineering" or technical experience I could. My desire to learn was high and I was enthusiastic. Now, I have come to do nearly all of the engineering and production work involved in the current Chautauqua show.

By "engineering" the show, I mean to say that I'm in charge of running all the studio equipment and controls necessary for broadcasting Chautauqua each day. In addition to my own responsibilities, one "telemix" operator sits in the studio with me to answer listener calls and get them on the air. He also monitors the:daily 
"aircheck" (which is simply a recording of the show). We tape the live show each day and often keep some of the outstanding shows to re-air if I'm sick or on vacation. And where they seem appropriate, we occasionally re-air short excerpts on upcoming Chautauquas.

If you have no radio experience, don't worry. The knowledge of radio production that you' 11 need to undertake a call-in show is easy to learn. Most Public Stations offer some sort of training program in order to teach new producers and "disc jockeys" how to work the equipment before putting them on the air. At smaller, more informal stations, there's always someone who's willing to spend time giving technical training to prospective program producers.

Although equipment from station to station varies a bit, if you stick with it, you should begin to feel comfortable and competent at doing some (or a11) of your own production work. Or perhaps, if you desire it, your station may assign a licensed station engineer to your show in order to assume the responsibilities for most of the "engineering."

In addition to learning how to operate turntables, tape machines, cart (tape cartridgc) machines, microphones, and "pots" (potentiometers-volume controls), you may become fairly knowledgeable in operating the equipment used to put listener phone-calls on the air.

There are a variety of systems designed to put teleplione calls on the air. Some of thcee systems have the capability of holding as many as four callers on the line while another caller is already on the air.

Fur Chautauqua, we now have three possible phone lines "tied" into broadcast. Although I started out with only two, 
I later convinced the station of the great advantages in having access to three separate phone lines for this show.

Let's say on phone-line "number one" I'm doing an hour-long interview with a fellow from northern ohio on tapping maple trees for syrup. If we have just two lines, that leaves only one other line for incoming calls. And although we'll probably be putting only one caller on the air at a time to talk to the maple-syrup fellow, the other listeners who are calling in to ask a question or share some information will get a busy signal.

But with a third phone line, we can accept another caller and put him "on hold" so that he will be ready to go on the air as soon as the other caller hangs up.

of course, it's possible to do a call-in show with only one or two phone lines, but you can't make full use of the potential for information exchange using these more limited systems. (See the attached specifications for some of the phone systems available).

The question may come up: "Should you use a tape-delay system for your call-in show?" Although each station in the country might have a different policy or idea about this, I have never used such a system for Chautauqua and have no reason to believe such a system is necessary for this show.

As a safeguard against prank calls, obscenity, etc., a tape-delay system offers about 7 seconds of time-lag between the time of actual interview and broadcast. That enables the host to cut off an inappropriate or obscene call before the 1 isteners actually hear it. 
As producer of Chautauqua, I take every measure within my control to ensure that no profane, slanderous, or obscene remarks are broadcast. But since Chautauqua is not the typical "call-in" which encourages controversy, heated political arguments, and the expression of opinions on touchy topics, we don't have that problem. I have actually never had to cut anyone off, nor had any slanderous or profane remarks on the show.

In addition to the equipment which makes possible the broadcast of telephone calls, there are all sorts of other technical systems which may be useful in the production of your cal1-in show.

For example, now that Public Radio Stations are hooked up to a satellite which allows them to receive and originate programs and materials for broadcast, stations can more easily share programs. If, for example, a regional call-in show in Missoula, Montana, does an interview worthy of sharing with other stations, the satellite might be the vehicle for sending this show to dozens of interested stations at once. If interested, other stations could either broadcast the program live, or tape it for broadcast at a time that's more convenient for their listeners.

But the satellite can also be used during the production of a show even if it's not being shared with other stations. For example, if energy-cxpcrt $\Lambda$ mory Lovins is visiting Boston on a Wednesday morning and he's agreed to talk to the people of Southeastern Ohio and West Virginia on Chautauqua, all he need do is be in the studio of the Public Radio Station in Boston at $9 \mathrm{a} . \mathrm{m}$. and we could both talk and have the listeners in Ohio call in and talk with him. 
The advantage of having $\mathrm{Mr}$. Lovins in a broadcast studio in Boston rather than talking to him at his hotel over the telephone is mainly one of quality. If we use the satellite and the high-quality microphones available at the Boston radio station, the listeners wouldn't be able to tell that he was not actually sitting next to me here in the studio in Athens, Ohio. Of course, it's a bit more involved than this, technically, and there are some costs involved, but my point is that the technology exists to permit an exchange of information which knows no barrier in distance. At some point, you may want to take advantage of this technology.

My hope is that as shows similar to Chautauqua spring up all over America, the producers of these shows will make use of the telephone, and perhaps the satellite, to develop a more elaborate information-exhange between regions-one that can further collect and distribute the wealth of information which exists on appropriate technology al1 across the country.

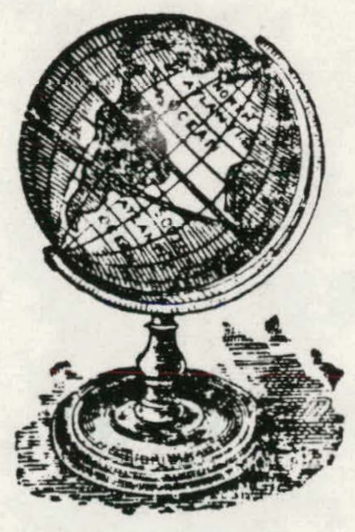




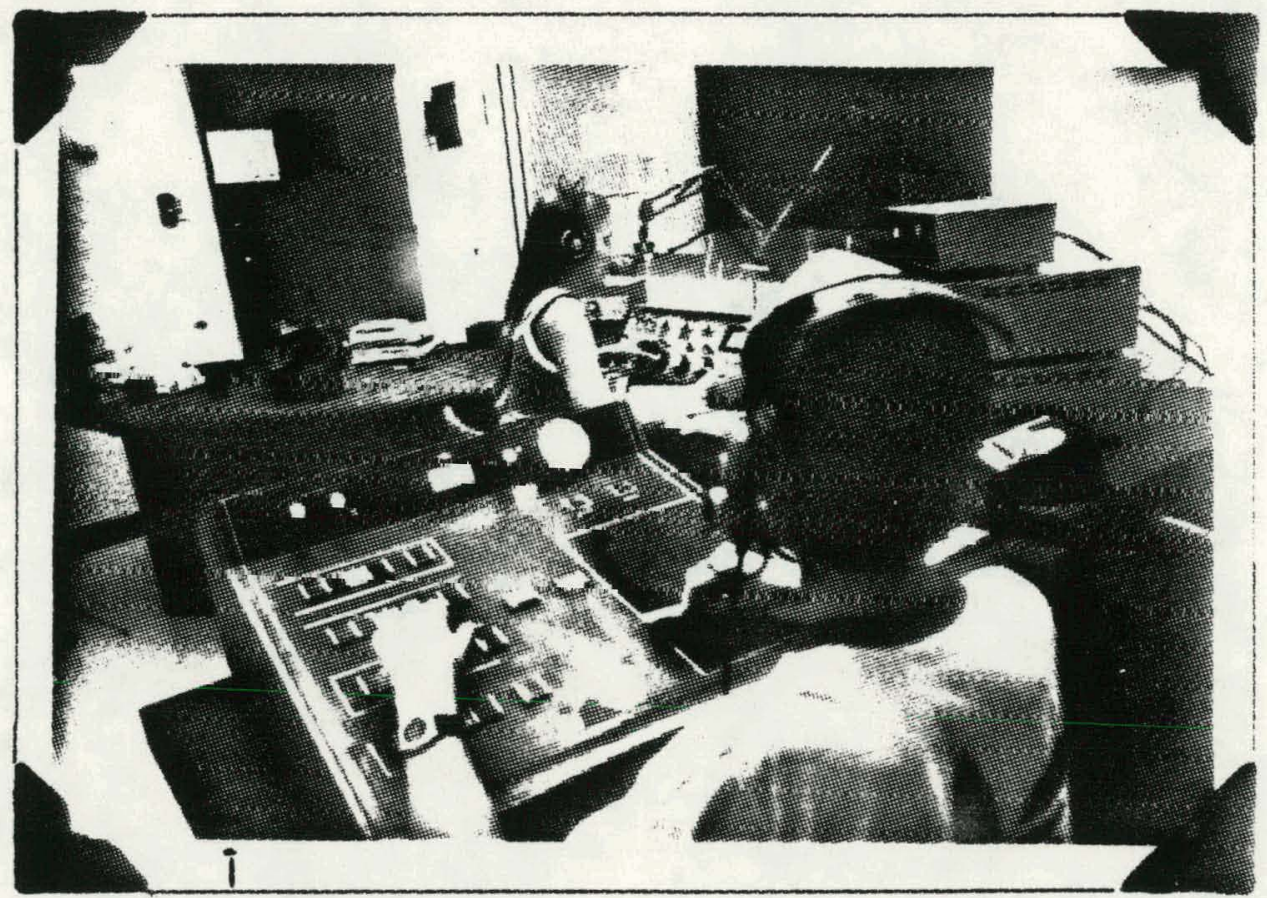

the telenix studio

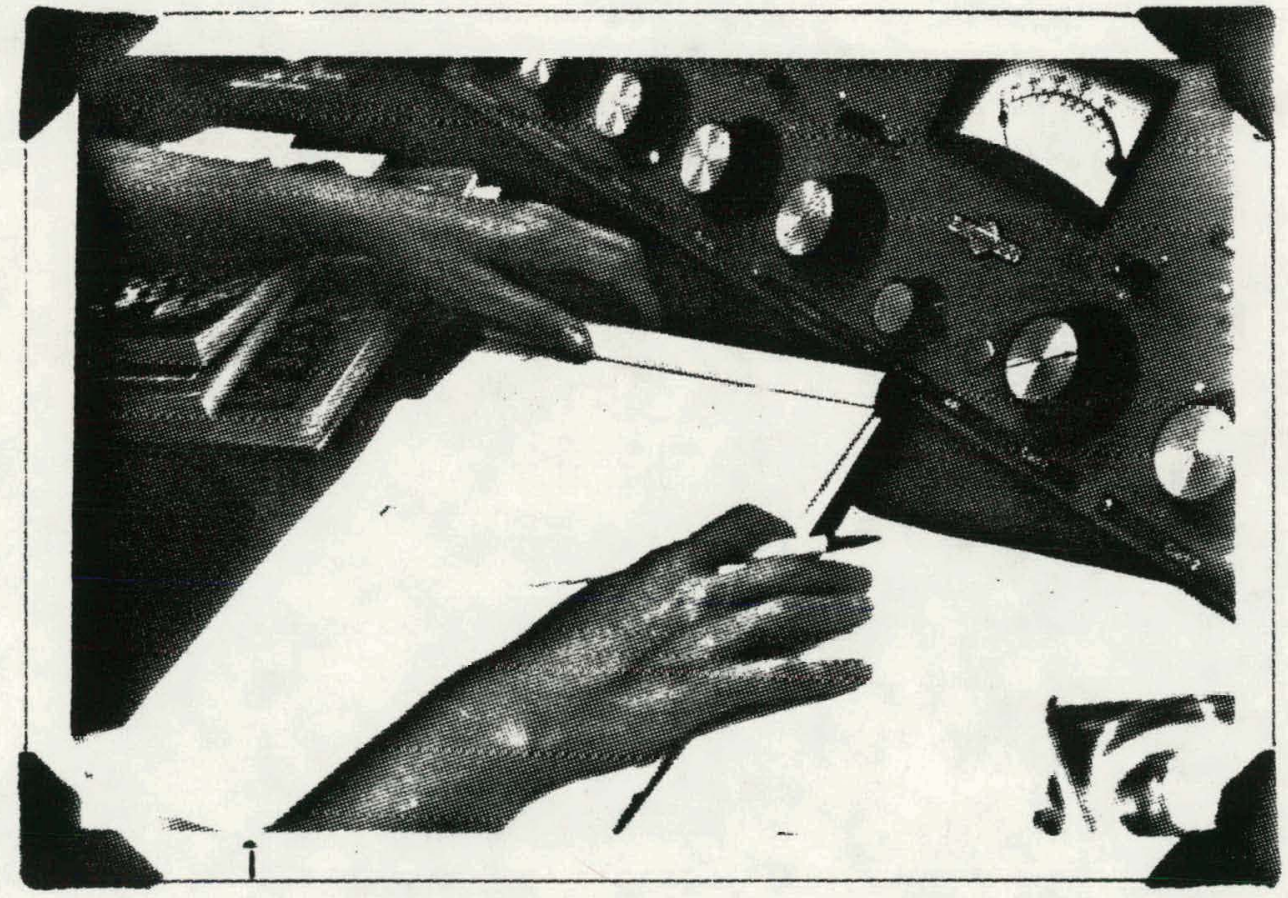


Budget 


\section{BUDGET}

The budget for a regional cal1-in show will vary with the type of equipment that's used, the personnel attached to the show, the length of the show, the frequency of its broadcast, and the time of day of its broadcast. For example, if the show were broadcast only once a week on Saturdays, the telephone costs associated with the program would be greatly reduced due to the lower weekend long-distance rates.

When the half-hour weekday version of Chautauqua began in November of 1977 , we really didn't plan out a budget in advance. Since I volunteered my time to produce and host" the show, costs for the program were minimal. However, here is an approximate budget for the first year of production. This budget includes only the "direct" costs for the station. The "indirect" costs (including office space, studio space, equipment maintenance, etc.) have not been calculated.

\section{First-Year Budget for Chautauqua (Half-hour version)}

Telephone Costs (for accepting "collect calls from listeners in the 32 -county WOUB 1 istening area)

Tape Costs (for "airchecks" \& production) 100.00 TOTAL 
In 1979, we applied for, and received, a grant from the National Center for Appropriate Technology (NCAT) in order to assist in the costs of expanding Chautauqua to an hour program each weekday morning. Here is the second-year budget submitted to NCAT for the hour-long version of the program. In this case, the WOUB column includes both the direct and the indirect contributions made by the station.

\section{Second-Year Budget for Chautaugua}

\section{(Hour version)}

COST CATEGORY

Personne1

Fringe Benefits

Travel

Space Costs \& Rental

Printing/Reproduction

Equipment

Purchased Parts \& Materials

Telephone \& other Direct Costs
NCAT WOUB $/$ OTHER

TOTAL

$$
\begin{array}{rrr}
\$ 12,000.00 & 2,186.00 & 14,186.00 \\
2,435.00 & & 2,435.00 \\
& 150.00 & 150.00 \\
250.00 & 500.00 & 750.00 \\
& 2,417.50 & 2,417.50 \\
115.00 & 585.00 & 700.00 \\
200.00 & 1,800.00 * & 2,000.00
\end{array}
$$

\section{TOTAL COSTS \\ OTHER INDIRECT COSTS \\ TOTAL PROJECT COSTS}

$$
\begin{array}{rrr}
\$ 15,000.00 & 12,787.08 & 27,787.08 \\
7,895.43 & 7,895.43 \\
\$ 15,000.00 & 20,682.51 & \$ 35,682.51
\end{array}
$$

*Subsequently, the local Community Action Agency provided a grant for $\$ 1800$ to cover telephone calls for the show.

NOTE: In actuality, not all of the funds appropriated in the WOUB/OTHER column were spent during the fiscal year. Some of the line-items in the budget were deleted. .

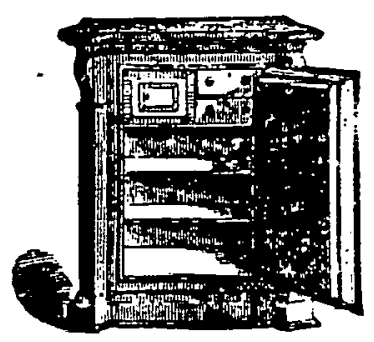




\section{Funding}


FUNDING

For some Public Radio stations, producing a cal1-in show similar to Chautauqua may hinge upon finding money through grants, underwriting, etc. to pay for phone costs, equipment, or even personnel. I'm optimistic about raising money locally and perhaps nationally for the production of radio information-exchanges on appropriate technology.

There are quite a number of national organizations, foundations, and government agencies. which have millions of dollars to give for a variety of conservation, energy, and appropriatetechnology projects. Although much of this money is aimed at funding research and development projects in the energy world, some of the money available through grants is aimed at "education" and the dissemination of information.

In applying for these grants, your job is to convince the funding agency or foundation that information-exchange. on radio is an excellent way to disseminate valuable information on appropriate technology. There seems to be an undeniable logic to collecting and disseminating information on appropriate technology by using two technolegies which are so readily availablc to millions of people: radio and telephone.

Although national funding seems an obvious possibility for financing your program, don't overlook the possibilities for local funding in your area. The second year Chautauqua was on the air, the local Community Action Agency appropriated $\$ 1800$ to cover telephone costs associated with the show. Fortunately, the board of directors for this Community Action Agency realized the impact that Chautaugua's practical how-to-do-it 
information could have on the low-income families and individuals in the area who are looking for ways to cope with inflation.

There are certainly other possibilities for local funding. For example, regional businesses may be willing to offer "underwriting" support and local co-ops or other non-profit organizations might be willing to help fund a portion of the show. Keep in mind the fact that you don't necessarily need to get any one group or foundation to fund the entire show. Sometimes, several groups may want to get involved. And once you've received one grant, it's sometimes easier to get a "matching" grant for an equal amount of money from another agency.

I also expect that radio 1 isteners, themselves, might be willing to help finance a call-in show of this sort through direct donations to the Public Radio Station. Once an information-exchange of this sort gets started and establishes a steady listenership, great potential exists to develop some method of "subscribing" to the show. Area listeners who can afford it might be asked to donate a "fee" of $\$ 10$ or $\$ 15$ each year to help support your show. Although the supporting listeners wouldn't be receiving a printed magazine, they would be subscribers to a "magazine on radio." Perhaps you could reward them with a free bumper-sticker, iron-on t-shirt transfer, or a button to help them make their "membership" more visible while at the same time publicizing your show. And certainly the $\$ 10$ or $\$ 15$ subscription would more than pay for itself in just the energy-saving, inflation-beating tips heard over the program during the course of the year. 
There is also a great potential for your show to become self-sustaining through the publishing and selling of a journal, a quarterly, or a book which contains how-to-do-it appropriate technology information (complete with illustrations) compiled from the show. Such a publication would be a valuable complement to the live radio show, itself. Local businesses may be able to offset the cost of such a magazine by purchasing display ads.

Once the program gets on the air, word gets out, and you've built a dedicated listening audience, you should find that funding possibilities for keeping it on the air become less and less of a problem.

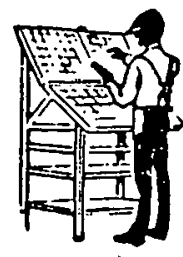




\section{StationPolicies}




\section{STATION POLICIES}

Each Public and Community Radio Station in the United States will, no doubt, have established some station policies guiding the production and broadcast of their programs. In addition to these individual station policies, there are also some general guidelines governing "Fairness Doctrine," live controversial broadcasts, legal responsibilities of announcer/host and station, etc. which are set down by the Federal Communications Commission (FCC).

Be sure to familiarize yourself with the rules and regulations which will affect you as a producer/host. The FCC rules can be found in the FCC Rules \& Regulations Handbook. Each station engineer and/or program director should have. a copy of this and should be most helpful in explaining or interpreting it for you.

One of the responsibilities you may need to check on with your radio station concerns the use of Talent Release Forms. These are short forms which are signed by guests or people interviewed giving their permission to be on the air. The individual policies concerning the use of such forms varies with different stations.

A11-in-all, each program director or some staff person, should be able to spend a bit of time with you and fill you in on the details concerning the operation of that particular station and its broadcast guidelines. Do spend some time discussing this right off the bat in order to get off on the right foot.

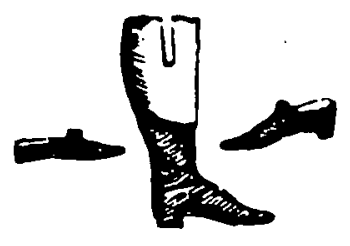

$\mathrm{N}-1$ 


\section{AFTERWORD}

Once Chautauqua became a success, there was talk of using the NPR satellite to syndicate it or "network" it in order to turn the program into a national call-in show.

But because the application of solar energy in New Mexico is different from that in Maine, because the planting season in Georgia is earlier than in Wisconsin, and because garden pests in Oregon vary from those in Arkansas, a national Chautauqua seemed not only impractical, it seemed at odds with the basic idea of decentralization-a major philosophical component of appropriate technology. After all, one of the strong points of Chautauqua is the fact that we can get into details of how to build:.and use a solar food-dryer geared towards our specific climate. Yet the creation of one :national Chautauqua show would demand a more generalized approach to appropriate-technology topics. For that reason, I opted instead for helping others to start versions of Chautauqua-like programs in their own areas. Hopefully, with time, dozens of call-in informationexchanges dealing with appropriate technology will spring up on: radio stations all around the country. And each will develop its own character, its own weekly features, its own favorite topics as it grows and strives to serve the 1 isteners in its own area of the country.

Because it is hoped that each version of Chautauqua will be unique in its own way, this Notebook is meant to be only a basic guide to help you get started and to help you avoid some of the mistakes I made when I first started out. Keep in mind the fact that each station, each area of the country, and each listening audience poses its own problems. I wish you great success in overcoming whatever obstacles you may encounter. 
And if you run into a genuine "crisis" (or if you just want to keep in touch and share your own experiences) feel free to write or call. Perhaps we'll be able to work out your problems together.

I sincerely hope that with the help of your 1 isteners, you will become enormously successful and self-reliant as the producer/host of your own radio program. I also hope that you will go on to explore other ways of using the medium to help the people of this country take control of their lives so that they can help to guide us towards a more sustainable and renewable future.

Best of luck,

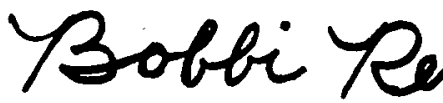

Bobbi Renz

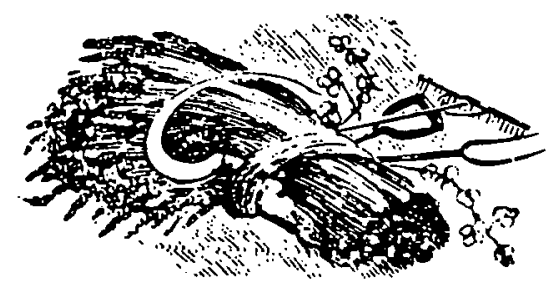


Appendix 


\section{SELECTED GOVERNMENT DOCUMENTS}

\section{AGRICULIUURE DPPARTIRE:TI}

Report and Recommendations on OrEanic Farming. 1980. 94 pp. A 1.2: Or $3 / 3$

Snall-Scale Fuel Alcohol Production--A 1.2: F 95

A 1.2: F 95

Nutrition and Your Health, Dietary Guidelines for Anericans

A 1.2: if $95 / 3$

Fireplaces and Chimneys.

A $1.9: 1889$

$A B C$ 's of Mendine

A 1.9: 1925

Preservation of Vegetables by Salting or Brining.

A 1.9: 1932

Selecting and Operating Beekeeping Equipment

A 1.2: 2204

Home Storage of Vegetailes and Fruits

A 1.9: 1939

Growing the Transplant Onion Crop.

A 1.9: 1956

Onion Set Production.

A 1.9: 1955

Savory Herbs, Culture and Use.

A 1.9: 1977

What Young Farm Families Should know About Credit. A 1.9: $2135 / 4$

Slautering. Cutting and Processing Pork on the Farm A 1.9: 2138

Hanaeing the Family Forest

A 1.9: 2187

Plumbing for the Home and Farmstead

A $1.9: 2213 / 6$

European Corn Borer . . How to Control It. A 1.9: 2190

Building a Pond.

A 1.9: 2256

Home Heating-Systems, Fuels, Controls

A 1.9:2235/3

Trees--949,

Agriculture Yearbooks. A 1.10: rear

Insects--952, Food--959

Plant Diseases--953. Protecting Our Food--966

Soil- -957

Land -9.958

Living on a Few Acres--979

Handbook for the liome--973

Energy for the Farm--980(not yet published)

Agriculture Leaflets-

A 1.35: nos. (there are too many to list all useful ones here, example follows)

Firewood for Your Fireplace, Selection, Purchase, Use.

A $1.35: 559 / 4$ 
Hotued and Propagating Frane

A $1.38: 986$

Plastic Covered Greenhouse [PIan]

A 1.38: 957

Display Stands for Farm Produce [Plans]

A 1.38: 1017

Solar-type Farm Cottage [Plans]

A 1.38: 1001

Greenhouse Framing for Plastic Covering [plans]

A 1.38: 1114

Planning the Electric Water System and Plumbing for joirr Farmstead

A $1.38: 674$

Factors Affecting the ijutritive Value of Foods

A 1.38: 664

Your Farmizouse, Insulation and Weatherproofine

A $1.30: 633$

Wind Pover and Windmills, Program Aid.

A 1.63: 1256 .

Pork, Facts for Consumer Education

A 1.75: 109

Dutch Flrn Disease and Its Control

A $1.75: 193$

lint Farming

A 1.75: 212

Calories and Weight--The USDA Pocket Guide

A $1.75: 364 / 2$

Ifutrition Labeling, Tools for Its Use

A 1.75: 382

Know The Soil You Build On.

A 1.75: 320

Control of Insects That Attack. Dry Beans and Peas in Storage

A 1.75: 303

Decorative Plants of Appalacia, Source of Income

A $1.75: 342$

Building jobby Greenhouses

A 1.75: 357

Belecting and Raising Rabbits

A 1.75: 358

Home Freezing of Poultry and Poultry Main Dishes

A 1.75: 371

Growing Fruits and Wuts

A 1.75: 408

Low-Cost Wood Homes for Rural America--Construction Manual.

A $1.76: 36 \% / 3$

Conserving the ilutritive Values in Foods. A 1.77: $90 / 5$

Storing Vegețables and Fruits in Basements, Cellars, Outbuildings, and Pits A $1.77: 119 / 4$

Control of Insects on Deciduous Fruits and Tree iluts in the Home Orchard-Without Insecticides. A 1.77: $211 / 2$

Gasohol: Prospects and Implications

$\Lambda 1.107: 458$

Crosscut Saw Manual

A 13.36/2: Sa 9 
A Guide to liedicinal Plants of Appalacia. $291 \mathrm{pp}$.

A 13.73: itt-138

A Checklist of Comon Plants of the Appalacian Trail in the George

Vashington National Forest, Virginia.

A 13.79: Së-288

Managing Young Stands for Firerood

A 13.102: 19

"Solar Home Heating" in April '77 Arricultural Researcl

A 77.12: 25/10

liow to Start a Cooperative

A $105.38 / 2: 7$

COR:LERCE DEPARTIEIT

Iow to Improve the Efficiency of Your Oil Fired Furnace

C 13.16: 1085

COMUIIIYY SERVICES ADMINISTRATION

Save Energy: Save Honey!

CSA 1.9: $6143 / 5-2$

Wo Heat, iNo Rent: An Urban Solar and Energy Conservation Manual CSA 1.9: 6143-7

Windmill Power for City People

CSA 1.9: 6143-8

Community Planning for Home Heating Emergencies

CSA 1.9: 6143-15

\section{EIIERGY DEPARTI:IEITT}

Solar Hot Water and Your Home

E 1.2: So $4 / 3 \& / 16 \& / 11$

Energy Conservation in the Home, an Enerey Education Conservation Curriculum Guide for Home Economics Teachers

E 1.8: H 75/Sample

Solar Energy for Heating Greenhouse-Residential Combinations E 1.10: 770367

Conference on Solar Energy for Heatine of Greenhouses and Greenhouse-Residence Combinations.

E 1.10: 7804110

65 Ways to Save IJatural Gas. E 1.25: 005

Fuels from Biomass

E 1.25: 006/2

How to Improve the Efficiency of Your Oil Fired Furnace

E 1.25: 0018

Winter Survival, A Consumer's Guide to Winter Preparedness E 1.25: 0019

27 EnerES Films--16 mm, color... for Schools, Colleges, Libraries, Industry. E 1.25: 0034 
Mips for Energy Savers, In And Around the Home, On the Road. In the Marketplace E 1.26: 0020 and E 1.25: 0037

Vanpool Implementation handbook

E 1.26: 0080

Home Weatherization Manual

is 1.26: 0106

Reaching Up, Reachine Out: A Guide to Organizing Local Solar Events (Whole Earth Catalog-type format). 1979.'208 pp. E1.28: SERI/SP-62-326

Fuel from Farms--A Guide to Small Scale Ethanol Production. 1980. $160 \mathrm{pp}$. E 1.28: SERI/SP-451/519

Driver Efficiency Program llanual, Techniques and Resources for Conserving iransportation Fuel

E 1.26: 55957-1

Wind Energy, Science Activities in Energy

i 1.33: 0037

ruels from Vastes

I 1.27: 2

Fuels from Plants

E 1.57: I

Land for Biomass Farms, Growing Energy

A 1.107: 425

Sun Power for Farms

ER 1.2: $\mathrm{Su} \mathrm{7/3}$

Energr Conservation on Campus--FE 1.8: C 15/vols.

FEDERAL TRADE COMMISSIOIJ

How to Complain and Get Results

FT 1.2: C $73 / 3$

Post-Purchase Consumer Remedies, Policy Session

FT 1.2: C $76 / 7$

Credit Shopping Guide

F' $1.8 / 2$ : C 86

GOVERIREIIT PRIINTIISG OFFICE

Home Repairs and Improvements, Do It Yourself (Bibliography) GP 3.22: H $75 / 9$

Keep Informed, Consult These Government Publications (3ibliography)

GP 3.22: In $3 / 2$

Salvage and Recycling Bibliography

GP 3.22/2: $159 / 3$

The Consumer Information Catalog (General Services Adninistration). GS 11.9: year/no.

HEALTH AID HUIAIN SERVICES DEPARTMEIFT

People Power, What Communities are Doing to Counter Inflation. 411 pp. 1980. HE 1.502: P 39

A Guide to Needs Assessment in Community Education HE 19.108: C 73/2

A Guide to Instructional Resources for Consumer's Education HE 19.108: C $76 / 2$ 
Catalog of Federal Education Assistance Progrars

HE: 19.127: year

How Different Sports Rate in Promoting Physical Fitness HE 20.102: Sp 6

Understanding Iutrition Labels HE 20.4002: if 95/4

Ifutrition Education of Youne Children

HE 23.1102: is 95

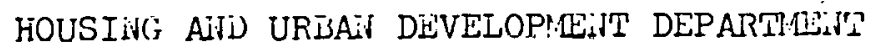

iNeighborhood Oriented Programs of the Federal Governnent: A Compendiurn of Funding and Technical Assistance Resources for lieighborhood Organizations HHI 1.2: if $31 / 14$

Neighborhoods: A Self-lielp Sampler $\mathrm{HH}$ 1.2: if $31 / 13$

Passive Design Ideas for the Energy Conscious Consurer lili 1,2: P 26

The First Passive solar Home Awards Hil 1.2: $\mathrm{P} 26 / 4$

Solar Drelling Design Concepts HH 1.2: So $4 / 3$

Solar inergr and Your Home HII 1.2: So $4 / 4$

Urban Horesteading Catalog HH 1.2: Ur $1 / 1 \% /$ vols.

In the Bank... Or Up the Chimney? Doilars and Cents Guide to Energy-Saving Home Inprovements. Hil $1.6 / 3$ : En $2 / 3 / 977$

The Inergs-Iise Ilome Buyer, A Guide to Selecting an Energy Efficient Home Hii $1.6 / 3$ : in $2 / 7$

Homebuyer's Information Package, A Guidebook for Buyint and Owning a Home IH $1.6 / 3$ : H $75 / 4$

Guide to the Inspection of Existing homes for Wood-Inhabiting Fungi and Insects. HH $1.6 / 3:$ In $7 / 2$

Solar Greenhouse Bibliography $\mathrm{HH} 1.23 / 6:$ G 83

HUD, Challenge (Vol. T, No. 3 devoted to "Comunity Gardens".) 1980. 31 pp. HH. $1.36: 11 / 7$

INeighborhood Self-Help Development HH 1.76: 2

\section{IHTERIOR DEPARTMEIST}

Let's Plant a Tree.

I 1.101: T 71

Water Well Location By Fracture Trace Mapping

I 1.103: $1 \mathrm{~N} 45$

INATIOIJAL ACADEMY OF SCIEINCES

Methane Generation from Human, Animal and Agricultural Wastes

IIA 1.2: is 56 


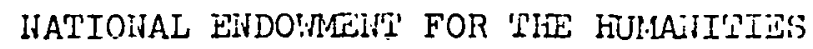

ifeighborhoods: Revitalization By Design

IIF 2.2: if 31

INATIONAL SCIEINCE FOUINATIOH

Appropriate Technology and Agriculture in the United States

IIS $1.2: A_{C} 8$

Alternatives in Energy Conservation, The Use of Earth Covered Buildings IIS 1.2: En 2/8

Wind Energy Developments in the 20th Century iN 1.2 : 72

Wind liachines

IIS 1.2: iv $72 / 2$

EXECIITIVE OFFICE OF TIE PRESIDEIII

Catalogue of Federal Domestic Assistance

PrEx 2.20: year

TREASURY DEPARTMEITT

Alcohol Fuel Plants

T 70.2: AI $1 / 3$

\section{TRAISSPORTATION DEPARTMEIII}

Bicycle Transportation for Energy Conservation

iD 1.2: B $47 / 4$

Blcycle Safety Education: A Guide to Resources and linterials

ID $1.15 / 2:$ B 47

Safety and Location Criteria for Bicycle Facilities

$\mathrm{mD} 2.30: 75-112$

Regional Workshops on Bicycle Safety: Presentations, Participant Problems, Programs and Ideas, and Recomrendations, Final Report TD 8,2: B $47 / 3$

Bicycle Safety Highway Users Information

TD 8.2: B 99 (microfiche)

U.S. INATIONAL ALCOHOL FUELS COMAISSION

Alcohol Fuel Tax Incentives

Y.3. AI $1: 2$ Al $1 / 2$

\section{U.S. CONSUMER PRODUCT SAFETY CORAISSIOI}

Bicycles, Buy Right--Drive Right

Y 3. C $76 / 3$ : 2 B $47 / 976$

Questions and Answers on Home Insulation

Y 3. C 76/3: 2 H 75/2

Sprocket llan. (Full. blown Spider and Batman comic book type for bicycle safety) Y 3. C $76 / 3: 2 \mathrm{Sp} 8$ 
Bicycle Built for You, Care, Cautions, and Creative Activities

Y 3. C $76 / 3: 8$ B $47 / 4$

Fireplaces

Y 3. C $76 / 3: 11 / 44 / 980$

Wood and Coal Burning Heating Stoves

Y 3. C $76 / 3$ : L 11/92/979

IATIOHAL ADVISORY COUNCIL OH ADULT EDUCATIOH

Terms, Definitions, Organizations and Councils Associated with Adult Learning Y 3. Ed 8/4: Ad $9 / 3$

WATER RESOURCES COUNCIL

Essentials of Ground-Water Hydrology Pertinent to Wate-Resources Planning Y 3. W 29: $3 / 16 / \mathrm{rev}$,

COIIGRESSTOHAL HEARIIIGS

National Fuel Alcohol and Farm Commodity Production Act of 1979

Y 4. $\mathrm{Ag} \mathrm{8/I:96-J}$

Agricultural Vaste Products as Alternative Energy Sources

Y 4. $\mathrm{Ag}$ 8/3: $\mathrm{V} 28$

Public Broadcasting Financing Act of 1978

Y 4. In 8/4: $95-186$

Automobile Repairs, Avoidable Costs

$Y$ 4. In 8/4: Au 8/8

These government documents can usually be obtained through your

local government depository library, or by utilizing local inter-library

loan facilities who can usually get them for you fror the Regional

Depository for your area.

The titles are as they appear on the documents and the numbers listed

are SuDoc (Superintendent of Documents) classifications.

Please note: this bibliography is nowhere near exlaustive of any subject in government documents.

This selective bibliography was produced by the staff of the

Government Documents Department, Ohio University Library, Athens, Ohio, 4570l, September 25, 1980, and all or part of it may be reproduced for educational purposes. 
TELEPHONE SYSTEMS FOR CALL-IN SHOWS

There are several systems which permit a station to broadcast telephone calls. Some of the systems are provided entirely by the telephone company while others are "hybrids" and use a combination of either purchased or custom-built equipment along with the necessary telephone lines provided by the telephone company.

In addition to the variety of equipment available, there are also a variety of ways to hook up this equipment to the studio "control board."

Keep in mind that no matter which of the following systems your station chooses to use for your show, if you plan to "screen" telephone calls or if you plan to accept "collect" calls (which requires talking to the telephone operator) you will need to have another person working with you.

\section{SINGLE-LINE TELEPHONE WITH PASSIVE VOICE COUPLER:}

This system uses a single telephone, a telephone line, and a "voice coupler" (QKT arrangement). It is often used by radio stations to broadcast sporting events. The entire system is provided by the phone company and includes:

1) A wall or a desk telephone with a ringer

2) Either a "push-to-talk" handset-which has a button you must push when you want to talk to the listeneror an "exclusion key" which allows you to disconnect the tiny microphone in the telephone mouthpiece when you're not talking to the 1 istener.

3) A passive "voice coupler" with a 1/4-inch "jack" that can be connected with a phone-plug to the studio control board or to a tape machine.

In short, this system consists of nothing more than an incoming telephone line, a telephone and a plug to connect it to the control board in the studio.

ADVANTAGES: Low monthly cost.

LIMITATIONS: Only one caller can call in at a time. The host must hold the telephone receiver to talk to the caller in addition to talking into the microphone.

COSTS: Installation: $\$ 50$

Monthly Costs: $\$ 25$ for telephone line

5 for QKT

8 for Voice Coupler. 
MULTIPLE-LINE TELEPHONE WITH PASSIVE VOICE COUPLER:

Also provided by the telephone company, this system uses a multi-line telephone with a hold-button which allows the caller to hear music (or, in this case, your program) while on hold, and an optional "telepatcher."

This multi-line phone arrangement allows several 1 isteners to call into the show at once and since they' 11 be able to hear the show while they're "on hold," they won't have to turn up their radio (which can cause feedback-high-pitched squealing-if turned up too loud in the same room with the telephone when the caller is put on the air).

While they're "on hold" waiting to go on the air, the telephone lines blink to indicate that a caller is waiting, just as they do on any ordinary business telephone.

A "telepatch" added to this system would allow more than one caller (or a telephone guest and a caller) to be put on the air at the same time.

To improve the quality somewhat, a "recorder coupler" (rather than a voice coupler) could be requested from the telephone company. This would allow the audio from the phone-1ine to be connected to equipment that would limit the volume and filter the sound. However, if requesting a "recorder coupler," be sure to request one without a "beep tone."

ADVANTAGES: Fairly low monthly cost. This system allows more than one caller at a time. It allows the caller to hear the program while they're on hold.

And with the use of a telepatch, it allows for more than one. caller to be put on the air at the same time.

LIMITATIONS: The host must talk into the telephone receiver as well as into the microphone.

COSTS: Installation: $\$ 100$

Monthly Costs: 25 per line

QKT

8 Voice Coupler

20 System Charge

13 Telepatch 


\section{CUSTOM-ASSEMBLED "HYBRID" SYSTEM}

By purchasing various pieces of equipment from manufacturers and connecting them to one or more telephone lines provided by the telephone company, an electronic "hybrid" system can be assembled.

The "hybrid", itself, is the piece of equipment which interfaces with the telephone line. By controlling. the sound-level of the host's voice in:order to avoid feedback within the system, it allows you to send and receive audio at the same time-just as with a regular telephone. In other words, you needn't press a button each time you talk to the caller and you don't need to hold a teelphone handset as with the other systems.

Once the telephone company installs a telephone line and a "jack," it can be connected to the hybrid equipment and then to the control board. If multiple-1ines are to be used with the hybrid system, you'11 need a multiline phone, a multi-line "keystrip" and a telephone" jack."

Here's how this system would work during the show:

The assistant would answer the caller on the multi-line telephone and put them on hold. The buttons on the host's "keystrip" would flash indicating that a caller was waiting. Then, to put the caller on the air, the host would push the appropriate flashing button the the "keystrip" and the call would then be sent to the hybrid through the telephone jack. So that the last caller can be "cleared" off the air, there should be at least one blank (dead-line) button on the "keystrip."

As with the other systems, a "telepatch" could be used in order to put more than one caller on the air at the same time. For best results, some arrangement should be made to feed the microphone audio to the hybrid without leeding the progrem audio to the hybrid. An appropriatelywired two-channel control board can fulfill this need.

ADVANTAGES: Since the caller can hear the host's questions and answers through the hybrid, the host can simply operate the control board without holding a telephone handset. This system can be used with either a single or a multiple-line system and with a telepatch, allows more than one caller to be put on the air at once.

LIMITATIONS: Relatively high initial costs for purchase of equipment. Customized installation by the station engineer.

CosTS: Initial Equipment Costs: $\$ 600$ to $\$ 1200$ per unit Installation costs: Approximately 100 Monthly Costs:

25 per line

5 QKT

20 System Charge

13 Telepatcher 


\section{CUSTOM-BUILT "TELEMIX" SYSTEM}

One step beyond the hybrid system is to custom build a telemix system which interfaces with the telephone company's lines. This system allows for several telephone lines to be used, several callers to be on the air at a time, and eliminates the need for the host to hold a telephone receiver while talking to the guest.

NOTE: Schematic \& block diagrams of the "telemix" system are available from the WOUB engineering department upon request. Have your station engineer write to"station Engineer, WOUB, Athens, OH, 45701!"

ADVANTAGES: The host can simply operate the control board without holding a telephone handset. Multiple-line phone systems can be used and more than one caller can be put on the air at once.

LIMITATIONS: Must be custom built by the station engineer. High initial cost.

CosTs: Initial Equipment Costs: Approximately $\$ 1000$ Monthly Costs: 


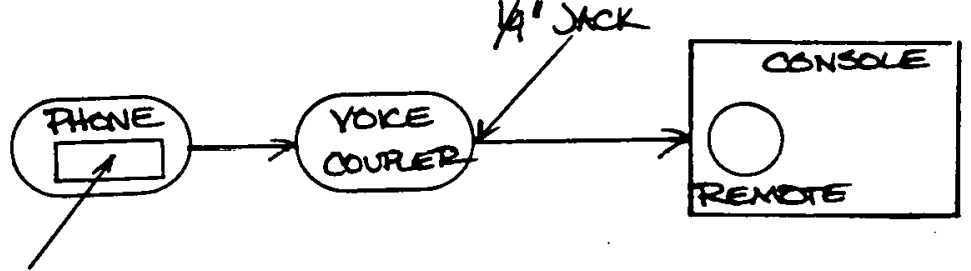

Pest-TO-TALK OR

Exclusion SWiteH

\section{MULT LINE PHONE WITH VOICE COUPLER}

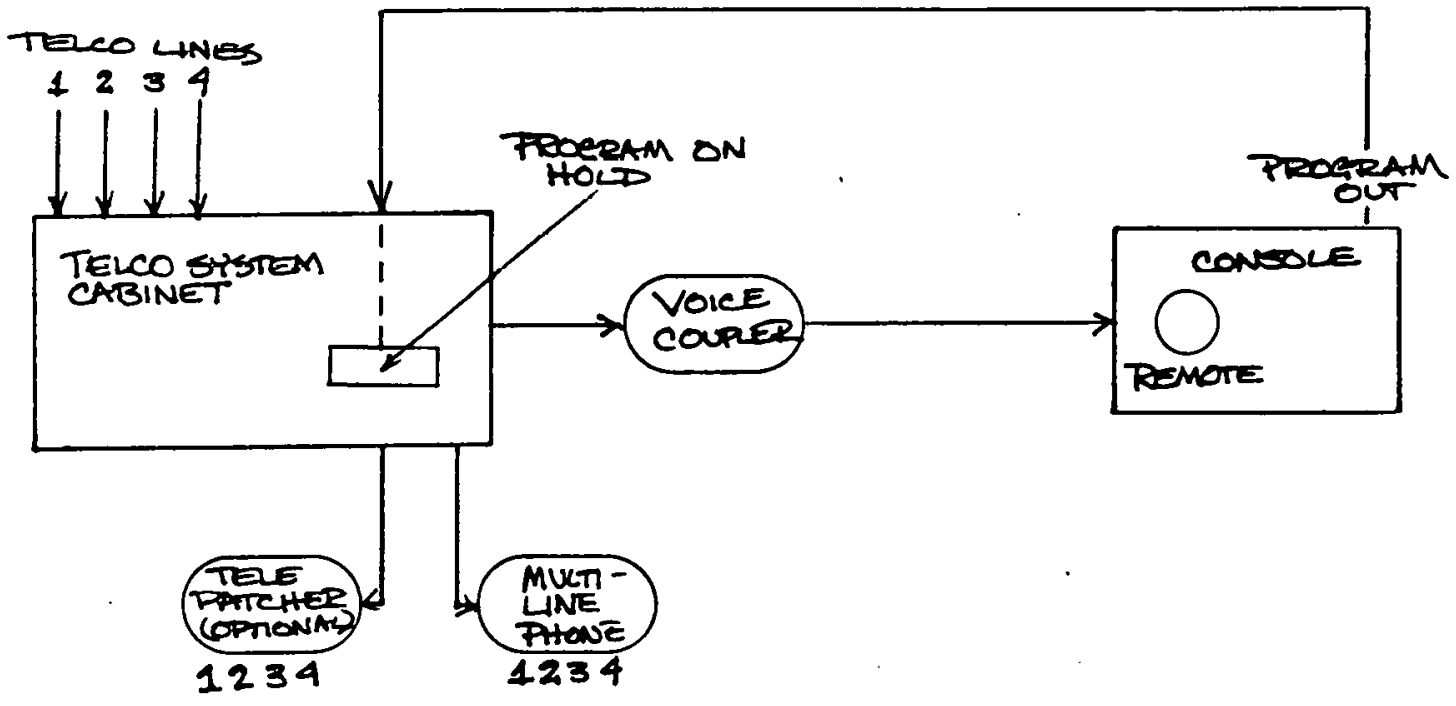

TELEMIX SYSTEM

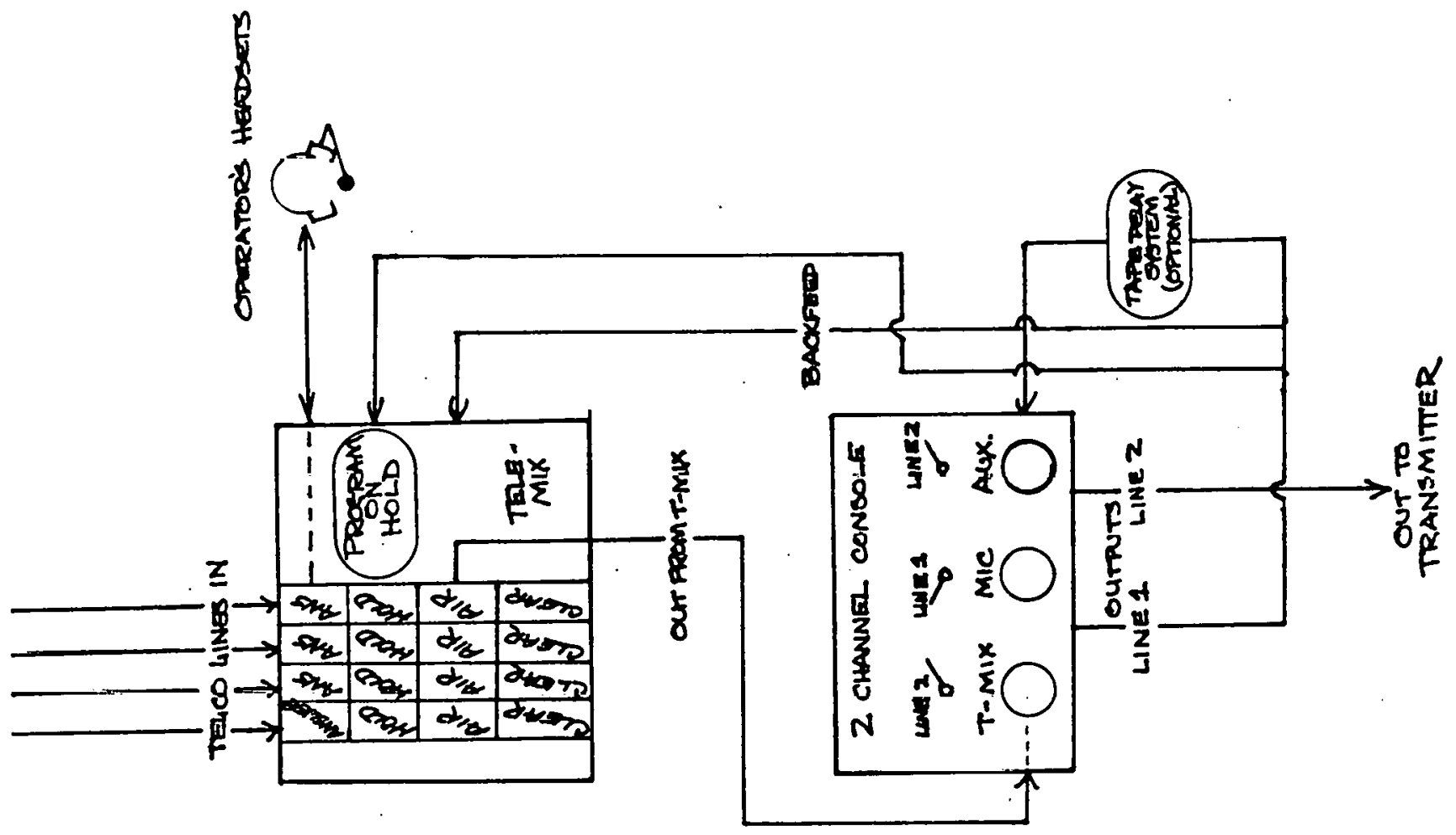




\section{TELEPHONE LINE COMPONENTS bY In}

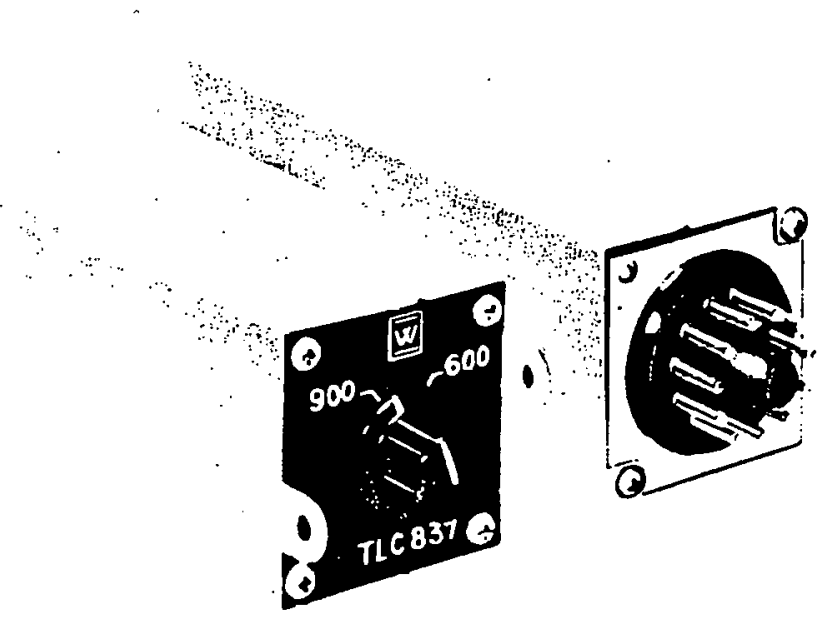

FUNCTION:

TLC837C Hybrid Coil Assembly is a plug-in unit for use in deriving 2-4 wire telephone circuits.

TLC837C is completely wired, containing the hybrid coils, a front panel impedance switch and two (2) $1.0 \mathrm{mfd} c \mathrm{c}-$ pacitors. All legs of the hybrid, including the $A$ and $B$ leads and the balancing winding are wired to the 11 pin amphenol plug. No compromise or signal bypass networks are provided within the unit. Designed primarily for use in the TLC 733,740 or 741 repeater systems, the unit may also be mounted in any suitable mounting plate equipped with uppropriate 11 pin sockets.

Although the small physicalsize of TLC837C makes it suitable for mounting in standard VF amplifier shelves, the hybrid coil is the same precision, high quality coiluised in the TLC701 find $711 \mathrm{tem}$. sets.

INSTALLATION:

Front panel mounted impedance switch is intemally wired to the hybrid coils so that either $600 \mathrm{or} 900 \mathrm{ohm}$, 2-wire circuits may be obtained. Two (2) $1.0 \mathrm{mfd}$ capacitors are wired in parallel in the hybrid balancing windings to offset signal bypass capacitance.

CAUTION: If $A$ and $B$ leads, or DC blocking of the 2-wire circuit (Tip and Ring), are not required, the $A$ and $B$ leads (Pins 5 and 6) must be strapped on the mating sncket and the two (2) $1.0 \mathrm{mfd}$ capacitors (C.1 and $\mathrm{C2}$ ) must be strapped out of the balance winding. (Cover of TLC837 must be removed to stap out $C_{1}$ and $C 2$ ). Capacitance for deriving $A$ and $B$ leads must be extemally provided.

Fxtemal hybrid balancing $n$ etworks, either compromise or precision types, must be used with TLC837C. TLC networks TLC852 thru TLC856 are suitable for such use. All of the above networks also contain signal bypass capacitors for deriving $A$ and $B$ leads from the TLC837.

When used in arrangements other than the TLC 733.740 or 741 repeater systems, wiring should be made direritv to the mating socket. Suggested for mounting are TLC904, 905 or, TLC 916 mounting shelves. TLC904 is for 19 " lack mounting, TLCgns for 23 " mounting, and TLC916 for KTU mountings. Appropriate balancing networks should be mounted adjacent to TLC837C.

Connections to the mating socket are as follows: (See figure 2)

2-Wire Branch: Tip to Pin 1

Ring to Pin 2

$A$ and $B$ Leads: $A$ to Pin 5

B to Pin 6

Transmit Branch: Tip to Pin 3 Ring to PIn 4

Reçeive Branch: Tip to Pin 8

Ring to Pin 7

Belance Network: To Pins 9 and 10

Chassis Ground: Pin 11

If $A$ and $B$ leads are used, connect pins 5 and 6 to bypass network in balancing network. See Caution note above.

NOTE: To obtain maximum return loss, the capacitance in the A-B lead circuit and the balancing windings (C1 \& $C 2$ ) must be equal. If $2.0 \mathrm{mfd}$ is used for signal bypass in the $A-B$ leads, $C 1$ \& $C 2$ must be in parallel. If $1.0 \mathrm{mfd}$ is used in the A-B lead circuit unsolder one side of C2 capacitor and tape back. 


\section{Electronics, Inc. \\ ESTABLISHED 1947}

369 LEXINGTON AVENUE • CLIFTON, N.J. 07015

phone: 201-546-3900

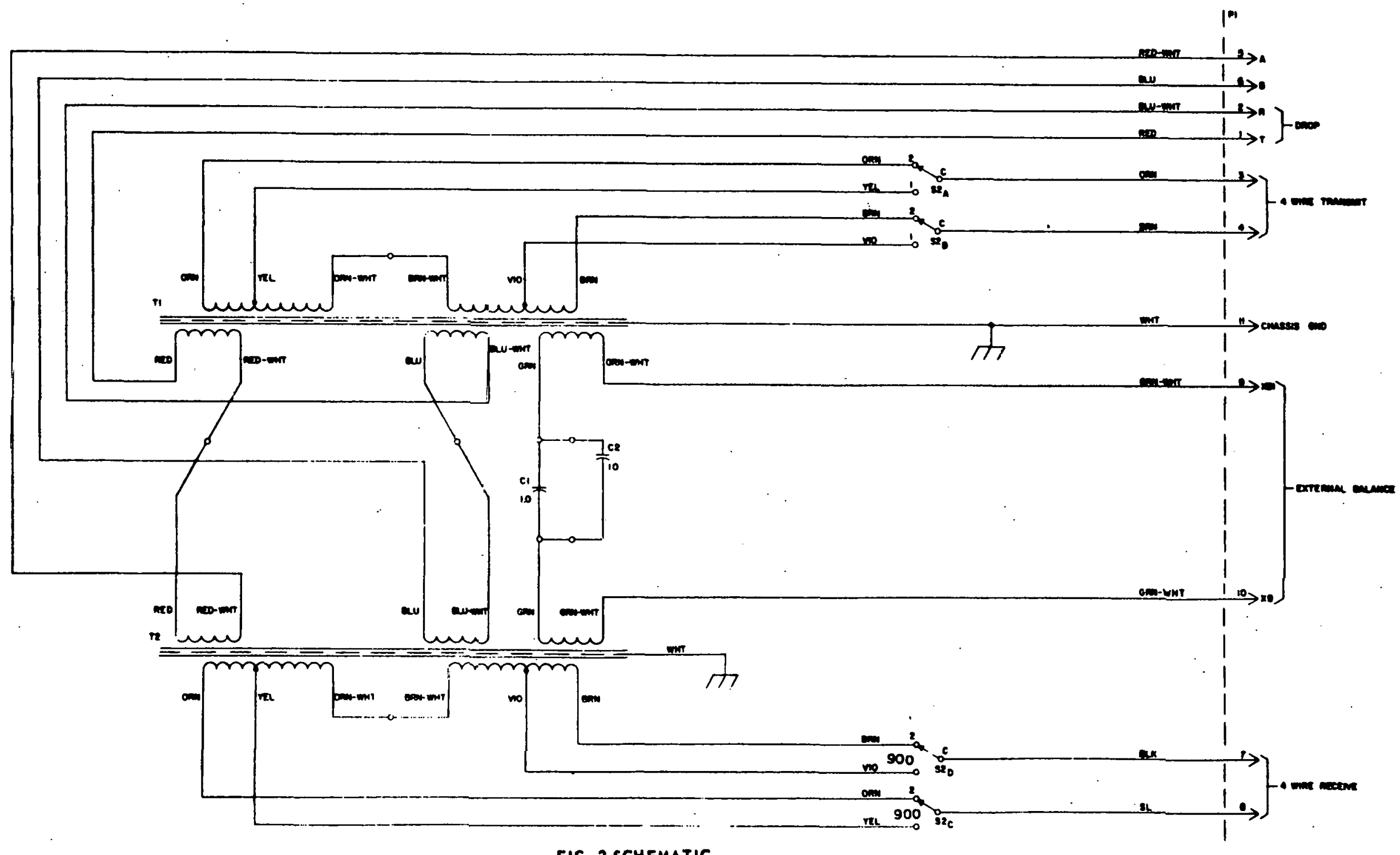

FIG. 2 SCHEMATIC 


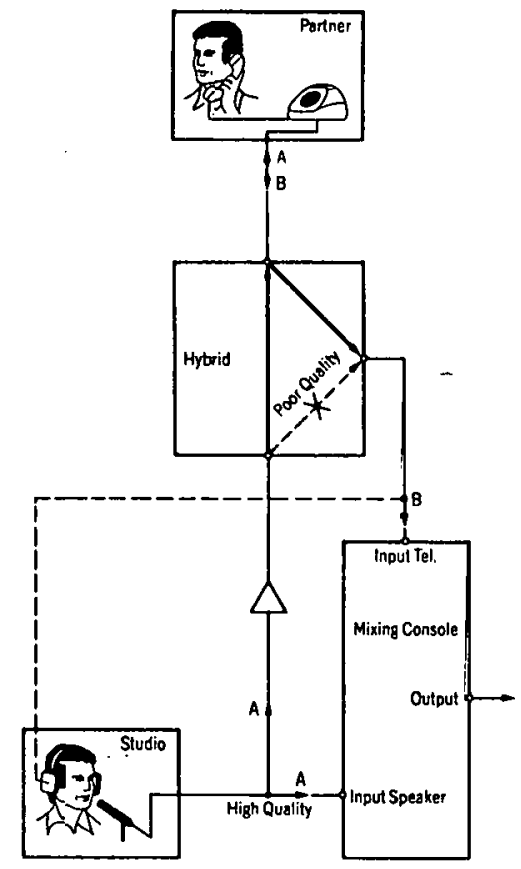

Example ol using one hybrid

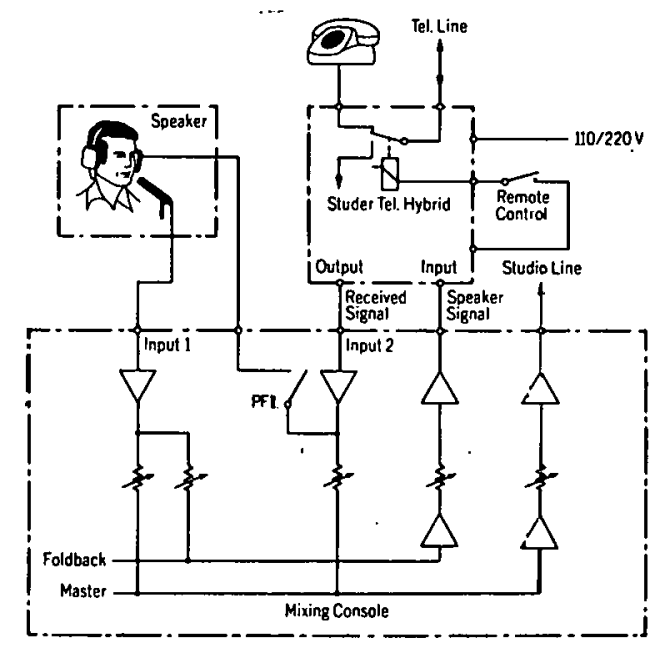

Example with two hybrids

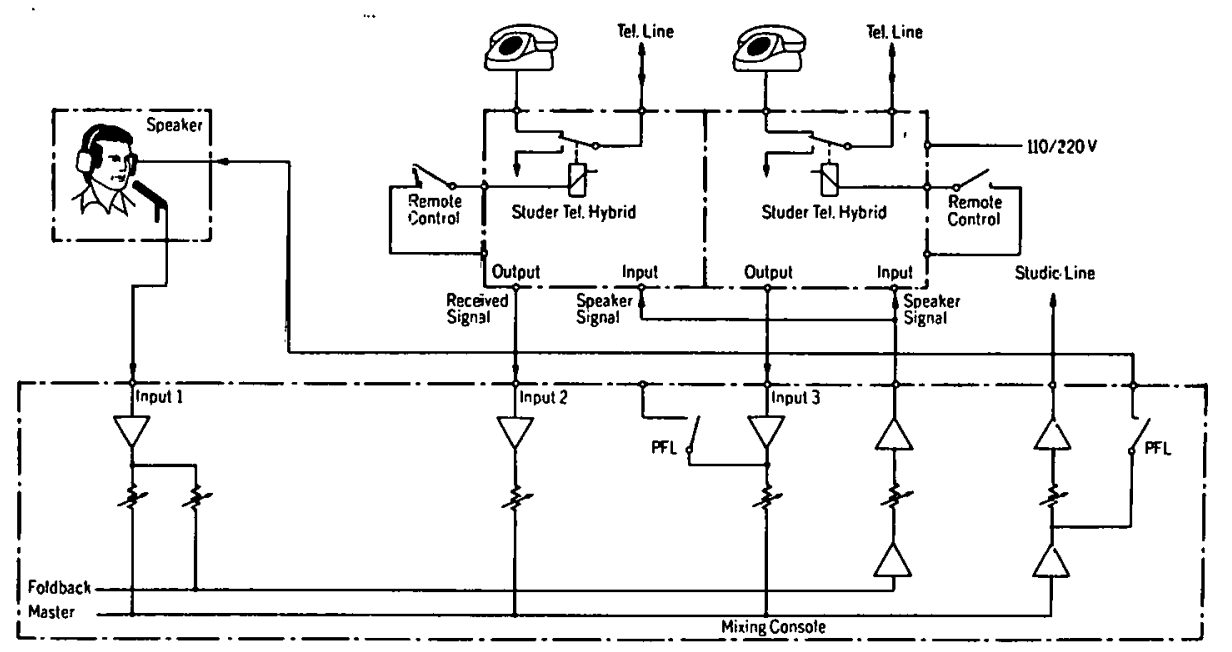


If the hybrid is connected direct to the exchange line, without passing through a telephone set, the $\mathrm{DC}$ resistance of the device (1.5 kohms) is no longer sufficient to make the relay in the exchange pick up. For this reason the $D C$ resistance is reduced by means of a choke to $200 \mathrm{ohms}$ in such a way as to have no effect on the line impedance.

The switching relay is activated with an external switch, and. switches the telephone line from the telephone to the hybrid.

Coarse tuning of the hybrid (inductive and real) is also pos. sible with the aid of 2 trimmers (accessible on removing the front panel). With this coarse adjustment it is possible to compensate any major deviations in the line impedance which may occur according to the type of exchange. The adjustment is made only once, as the connection is always to the same exchange.

- DC resistance of choke

- Inductance of choke

- DC current

- Balancing range: $R$ (real)

- Balancing range: $L$ (inductive)
The 19" module has space for the following circuit boards:

- 2 telephone hybrid boards 1.915 .760

- 1 dual relay unit $\quad 1.915 .762$

Included in the 19" frame is a power supply with the following data.

$\begin{array}{ll}\text { Input } & 110 \mathrm{~V} \text { to } 240 \mathrm{~V} \\ \text { Outputs: audio } & \pm 15 \mathrm{~V}, 0.5 \mathrm{~A} \\ & 24 \mathrm{~V}, 0.2 \mathrm{~A}\end{array}$

The audio outputs are taken to Cannon XLR connectors (input female, output male). The telephone inputs and out. puts are wired to terminal strips. A type D 15-pin connector is used for remote control of the relays.

Block diagram, telephone hybrid

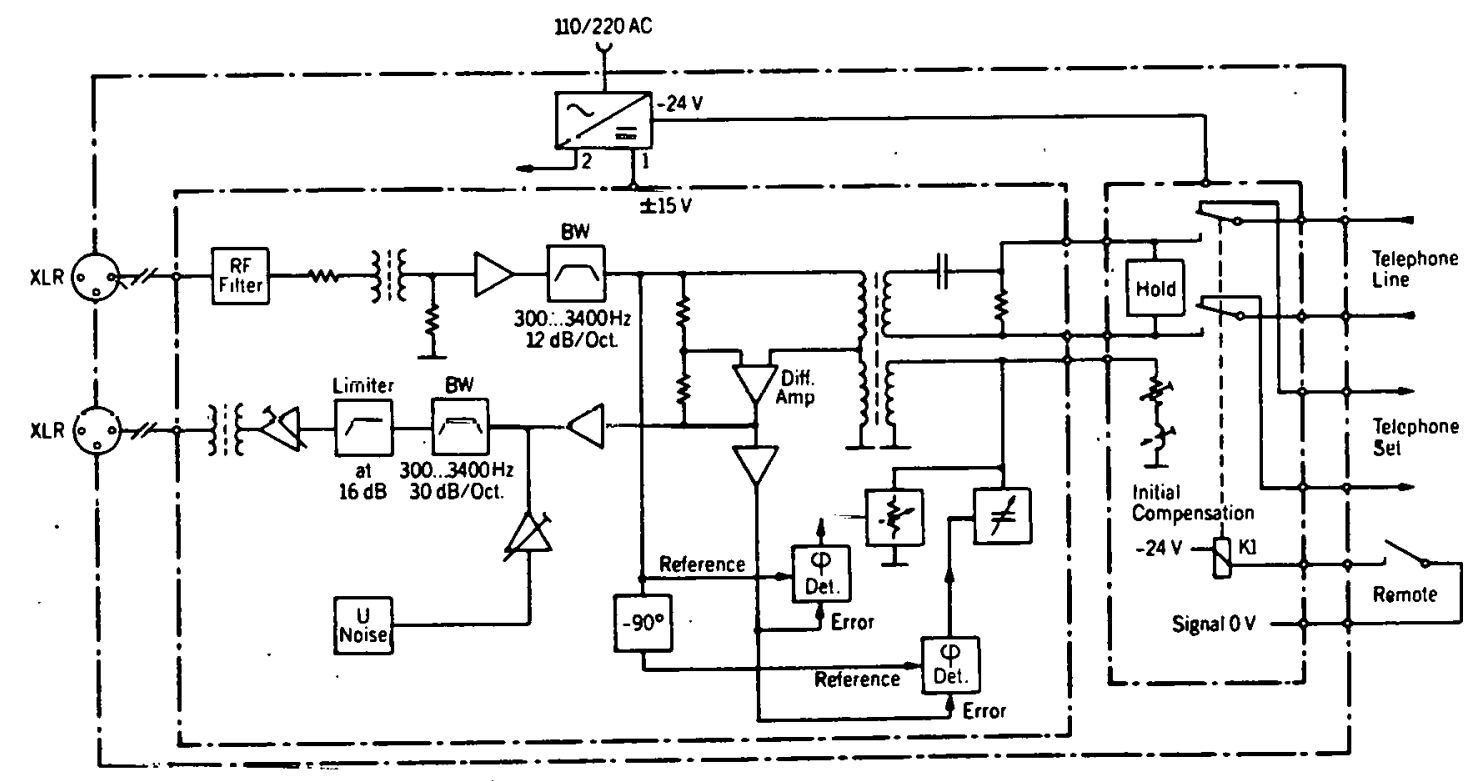


An Application for Funding to

The National Center

for Appropriate

Technology

from

The Ohio University Telecommications Center

Sponsored by Tri County Commity Action Agency 
PURPOSE:

Chautauqua began in November of 1977 as a part-time voluntarilyproduced radio program to allow for the exchange of information and ideas about self-reliance in Southeastern Ohio and West Virginia. Since then, the program's success has caused us to consider its potential and desirable expansion to enhance the role it now plays in the region. Expansion without additional external resources, however, is beyond our current capabilities. Thus, the following proposal outlines our goals, the necessary steps and the financial support to accomplish this task.

(Cassette tape containing Chautauqua excerpts and one full-length sample program sent to NCAT with this proposal.) 
The Ohio University Telecommunications Center Grant Proposal

TABLE OF OONTENTS

PROJECT IDENTIFICATION/INFORMATION $\ldots \ldots \ldots \ldots \ldots \ldots \ldots \ldots \ldots \ldots \ldots \ldots$, p. 1.

PROJECT SUMMARY AND PROGRAM EXPLANATION........................ p. 2 .

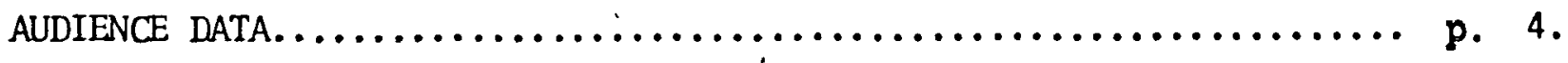

PROPOSED EXPANSION......................................... p. 5 .

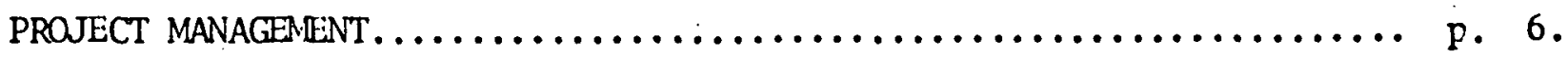

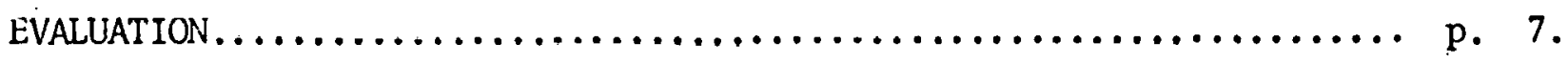

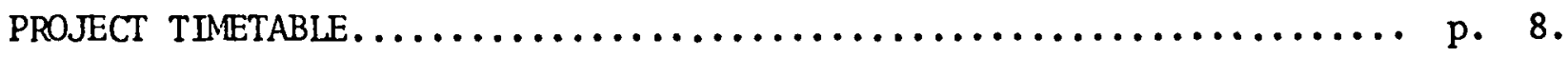

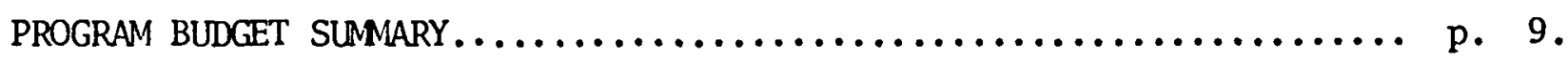

PROGRAM BUDGET SIIPPORT SHEET.............................. p. 10 .

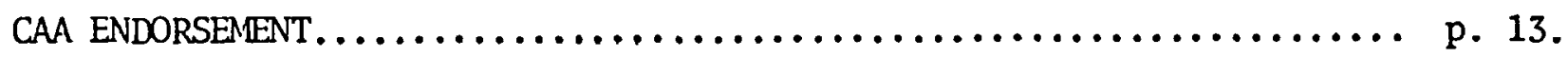

CERTIFICATE OF INCORPORATION................................ p. 14 .

IDENTIFICATION OF NON-PROFIT TAX STATUS........................ p. 18 .

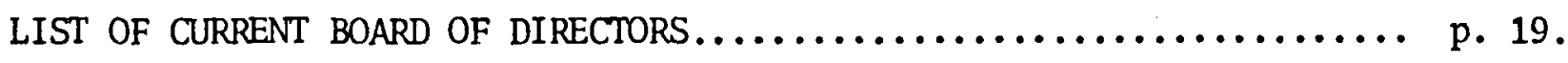

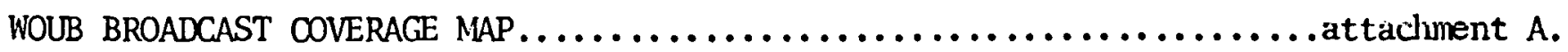

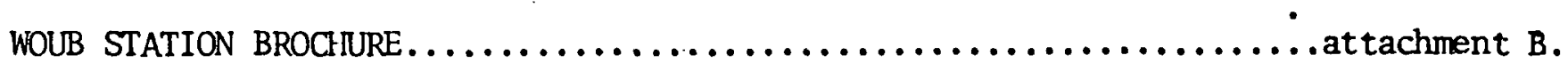

RESUME OF PROJECT DIRECTOR \& PRODUCER/HOST.$\ldots \ldots \ldots \ldots \ldots \ldots \ldots \ldots$. . . .

JOB DESCRIPTION FOR PROGRAM SUPPORT STAFF..........................

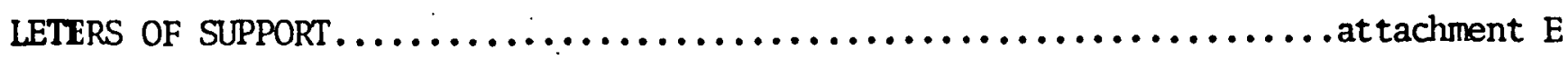


Date Received:

Proposal. No.

NATIONAL CENTER FOR APPROPRIATE TECHNOLOGY

\section{PROPOSAL FORM}

This form is for the purpose of submitting applications to NCAT for community experiments and demonstration grants. Ten (10) copies of. completed proposals should be sent to:

National Center for Appropriate Technology

P. 0. Box \#3838

Butte, Montana 59701

(406) 7.23-5474

For further information, please see:

"NCAT Grant Information".

A. PROJECT INFORMATION

1. Date Prepared August 24, 1978

2. CSA Grantee No. 50194

3. Federal Employer Identification No. 31-6402113

4. Applicant is:

O. CAA

$\bigcirc \operatorname{CDC}$

5. Applicant is a: 0 (X) Non-Profit Corporation. O Other
(X) Other: With CAA sponsor (see below)

6. Name of Applicant The Ohio University Telecommunications Center

Address: 9 S. College St

Athens, Ohio 45701 County: Athens

Director: David Kanzeg ( see attachment D. for

Project Director or Contact Contact: Bobbi Renz

Telephone No. _. 614-594-5301/ 614-594-5662

Project Title: CHAUTAUQUA

Sponsoring Organization (If different from Applicant)

(Name, Address) Tri County Community Action Agency

Athens, Ohio 45701

7. Congressional District 10th Ohio Congressional District *

*WOUB Serves the 10 th, 6 th \& 18th Ohio Congressional District And District '\#'r in West Virginia 
Chautauqua is a unique call-in talk show which is broadcast live at 9:00am Monday through Friday over public radio station WOUB FM (91.3). Thautauqua is unlike the stereo-type call-in talk show where controversial arguments are provoked or where listeners are encouraged to expound on their political views. Instead the energy of the producer / host, guests and listeners of Chautauqua is directed toward the sharing of information, ideas \& experiences for self-reliance. Chautauqua reflects an attitude in which a high priority is placed on doing-for-yourself, with attention and respect given to the resources at hand. One of the most valuable resources at hand happens to be people; and 'Chautauqua offers a direct line of access to this resource.

Each day listeners in 30 counties of Ohio and West Virginia have an opportunity to participate in the information exchange that takes place during Chautauqua. The format of the show includes interviews with guests on a regular basis. Many of these guests are local people who have valuable information to share. On these days listeners in the region call-in during the show with their questions and comments, and the guest responds. From time-to-time we have interviewed special guests from other parts of the US (outside our broadcast region)via phone lines. This feature of Chautauqua has been especially popular with the listeners because it often allows them access to information which isn't available locally. For example, if there is someone in Colorado who is experimenting with low-cost applications of solar energy which would be feasible in our locale, the listeners here would have a direct line to that information; and could consequently ask questions related to our specific climate and available resources etc. (This is one feature of the program which will be expanded to be a regular part 
of Chautauqua .) Utilizing the phone in this manner, seems to be a most appropriate use of the phone system technology and the results offer information to the people of Ohio and W. Virginia which may allow them to make more appropriate use of their local resources.

On days when there is no guest, the host and listeners provide much of the information. For example, a listener recently called-in during the show and asked how to build a low-cost root (or fruit) cellar. Within minutes other listeners were responding with a variety of low-cost, do-it-yourself root cellars.

The level and quality of listener participation is impressive. People of various ages and backgrounds participate, giving a broad perspective to each topic. We receive calls from many senior citizens wt.o relate information and methods of doing things which are nearly forgotten; much of this imformation has a new importance and is not readily available elsewhere. One of the added benefits of the show (in addition to the information) is the public recognition which is given to the people in our area who have developed knowledge and skills necessary for self-reliance. Much of this knowledge and skill is not given deserved recognition by traditional media.

A wide variety of topics is covered during Chautauqua. Here is a partial list of generalized topics duscussed in recent months on Chautauqua:

SMALL SCALE FOOD PRODUCTION (methods of organic gardening:building soil, companion planting, biological pest control, mulching, intensive gardening, weather related problems, community gardens, fruit trees, and info. on how to grow \& care for specific vegetables.)

PRESERVING FOOD: (drying, canning\& freezing produce, herbs etc., low coot root cellars)

PREPARING POOD: (smoking, curing meat, goud nutrition at low cost, high protein meat substitutes, homemade foods) 
RAISING LIVESTOCK: (sma1l scale livestock farming, fencing, beekeeping)

INDEPENDENT WATER SUPPLY: (construction $\&$ maintainence of ponds, cisterns, springs, wells, water conservation, energy efficient methods of pumping water)

LAND: BUYING SELLING \& OWNING: (legal aspects, agricultural potential, surveying rural septic systems, soil structure)

ENERGY: ( energy conservation tips on continuous basis, low-cost weatherization, wood heat; efficiency \& safety, solar greenhouse, passive solar energy, solar hot water heater, solar cooker etc., coal heat, recycling, nuclear power special.)

This is a generalized list of the topics which are a regular part of Chautauqua:All of the topics discussed during the program are approached with the low-income family as the target audience. (see description of audience that follows.) All people in our broadcast region are able to participate during the program by calling collect.

\section{AUDIENCE}

WOUB FM serves a potential audience of over one million people. The area of Appalachian Ohio \& W. Virginia which is served by WOUB has a significantly high percentage of low-income families. To give an indication of the actual income level information is included here which comes from a recent publication by the Corporation for Appalachina Development. Here is an income breakdown for an 8 county area in our broadcast region refered to as "Buckeye Hills/ Hocking Valley Region". The statistics from all 30 of the counties served by WOUB are similar to this example region: (figures reflect the 1975 estimated income)

Family Income under $\$ 3,000$.

Family Income $\$ 3,000 .-\$ 6,999$.

Fanily Income $\$ 7,000 .-\$ 8,999$.

Family Income $\$ 9,000$.-over

(Aside from the statistics, in reality the listeners of "Chautauqua" express needs for information on a day to day basis which indicates a low-income.) 


\section{EXPANSION OF CHAUTAUQUA}

Since the program Chautauqua began November 7,1977 it has grown tremendously. What began as a part-time voluntarily produced show has blossomed into a successful radio program which demands full attention. The listeners and participants are continuously encouraged to give suggestions and criticism about the show and have consequently responded with demands which necessitate expansion.

The expansion of Chautauqua will include the following:

A. hire full-time producer/host and support staff, and increase preliminary program research and preparation

B - interviews with guests on a regular basis (both local guests and far-away guests via the phone line)

C. special remote interviews to gather information locally which would not be available during the live program time-slot $(9: 00 \mathrm{am})$

$D$. the gathering and inclusion of short pre-recorded informational segments to use as stimulation for discussions \& to offer further informational value.

E. expansion of the role of liaison between Chautauqua and the various public service agencies, universities and similar resources which have information and people which would contribute greatly to "Chautauqua"

F . increase in broadcast time of Chautauqua to one hr. daily Monday-Friday (presently $\frac{1}{2}$ hr daily)

In addition to these elements of expansion which will benefit the listeners in Southeastern Ohio and W. Virginia, there is great potential for Chautauqua to serve as an example to other radio stations throughout the country. The approach to exchanging information via regional call-in talk shows has not yet been realized as an appropriate vehicle for dissemenating information for more individual and community reliance. Since WOUB is a member of the National Public Radio Network, the possibility exists for WOUB to have program input into that network (NPR). Many of the programs and specials heard during Chautauqua are appropriate to a general audience across the US regardless of climate etc. For this reason it would be beneficial to submit excerpts 
from Chautauqua to NPR for national broadcast, thus giving exposure to the idea of radio-call-in information \& idea exchange.

MANAGEMENT

Input from both NCAT and Tri County Commity Action Agency will be sought on a regular basis. Contacts and information for possible program topics will be requested from both agencies to enhance programming. Information concerning appropriate topics \& guests for Chautauqua is very valuable for the production of the show. If a special seminar or lecture is arranged by either agency perhaps that same speaker would be willing to appear on Chautauqua (1ive or via phone lines) and allow a large number of listeners to ask questions and benefit from the information resulting. Likewise just the names, phone numbers etc of resource people could prove fruitful in arranging phone interviews for specialized topics during Chautauqua . With open lines of commuication between WOUB, Tri.Co. Commmity Action Agency and NCAT an extensive list of resources and contacts should result. Of course, NCAT, as the funding agency will receive an underwriters identification announcement both before and after each daily program. ('This program mede possible in part by funds from the National Center for Appropriate Technology.) Likewise Tri. CAA will receive a production credit "Produced in co-operation with Tri Co. Commmity Action Agency" appearing at the conclusion of the program.

Chautauqua will be produced by WOUB Radio; the broadcast of the program will conform with all applicable federal regulations including those requiring faimess and balance in presentation. The actual program production will be the responsibility of the producer /host on a daily basis, with the Public Radio Program Director assuming the role of overseeing production including compliance with FCC rules \& regualtions. For billing purposes, WOUB will submit a program budget sumary to Tri cointy Community Action Agency each month for paynerit. 
The Nature of this program is such that immediate feedback is received from the listeners in the broadcast region. This characteristic allows for continuous and immediate evaluation of program contents, and it also is an indicator of the adjustments which need to be made to meet the specific needs of the people in S. E. Ohio and W. Virginia who are served by Chautauqua . Listeners are encouraged to respond to Chautauqua ; send their criticism, comments and suggestions for future shows. This information as well as data kept on the daily onaair phone calls \& topics discussed will be kept on file for review. 
Month 1: Grant Announcement

Recruitment of personnel \& training

Program length $\frac{1}{2} \mathrm{hr}$. daily (M-F) with some $1 \mathrm{hr}$. specials

Contacts made for programs

Month 2: Program length $\frac{1}{2} \mathrm{hr}$. daily, with some $1 \mathrm{hr}$. specials

Increase in research \& resource gathering for programming

Month 3: Program length $\frac{1}{2} \mathrm{hr}$. daily with some $1 \mathrm{hr}$. specials

Continue to gear-up for program expansion to $1 \mathrm{hr}$. ( contacts,pre-recorded

interviews, information segments gathered, promotional announcements included)

Month 4: With support material in place program will go $1 \mathrm{hr}$. daily (M-F)

Continued promotion of expansion

Month 5; Program length $1 \mathrm{hr}$. daily (M-F) with support information in place Actively seek year 2 funding.

Month 6: Program length $1 \mathrm{hr}$. daily(M-f) with support information in place 6 month evaluation $\&$ review

Month 7: Program length $1 \mathrm{hr}$. daily (M-F) with support information in place

Month 8: Program length $1 \mathrm{hr}$. daily (M-F) with support information in place

Month 9: Program length $1 \mathrm{hr}$. daily $(M-F)$ with support information in place

Month 10: Program length $1 \mathrm{hr}$. daily (M-F) with support information in place

Month 11: Program length $1 \mathrm{hr}$. daily (M-F) with support information in place

Month 12: Program length $1 \mathrm{hr}$. daily (M-F) with support information in place Notification of year two funding. 
REVISED

PROGRAM BUDGET SUMAARY

\begin{tabular}{|c|c|c|c|c|}
\hline $\begin{array}{l}\text { Cost } \\
\text { Category } \\
\text { Number }\end{array}$ & $\begin{array}{l}\text { Cost } \\
\text { Category }\end{array}$ & NCAT & OTHER & TOTAL \\
\hline 1. & Personne1.. & $\$ 12,000.00$ & $2,186.00$ & $14,186.00$ \\
\hline 2. & Fringe Benefits & $2,435.00$ & & $2,435.00$ \\
\hline 3. & Consultants. & & & \\
\hline 4. & Trave 1 & & 150.00 & 150.00 \\
\hline 5. & Space Costs \& Rental & & $5,148.58$ & $5,148.58$ \\
\hline 6. & Consumable Supplies & & & \\
\hline 7. & Printing/Reproduction & $\therefore 250$ & 500.00 & 750.00 \\
\hline 8. & Equipment & & $2,417.50$ & $2,417.50$ \\
\hline 9. & Purchased Parts \& Materials & 115 & 585.00 & $700: 00$ \\
\hline 10. & Other Direct Costs & 200 & $1,800.00$ & $2,000.00$ \\
\hline & TOTAL DIRECT COSTS & $\$ 15,000.00$ & $12,787.08$ & $27,787.08$ \\
\hline & INDIRECT COSTS & & $7,895.43$ & $7,895.43$ \\
\hline TOT & L PROJECT COSTS & $15,000.00$ & $20,682.51$ & $35,682.51$ \\
\hline
\end{tabular}


E. PROGRAM BUDGE. - JPPORT SHEET

Page 1 of 3

(Use additional sheets if necessary)

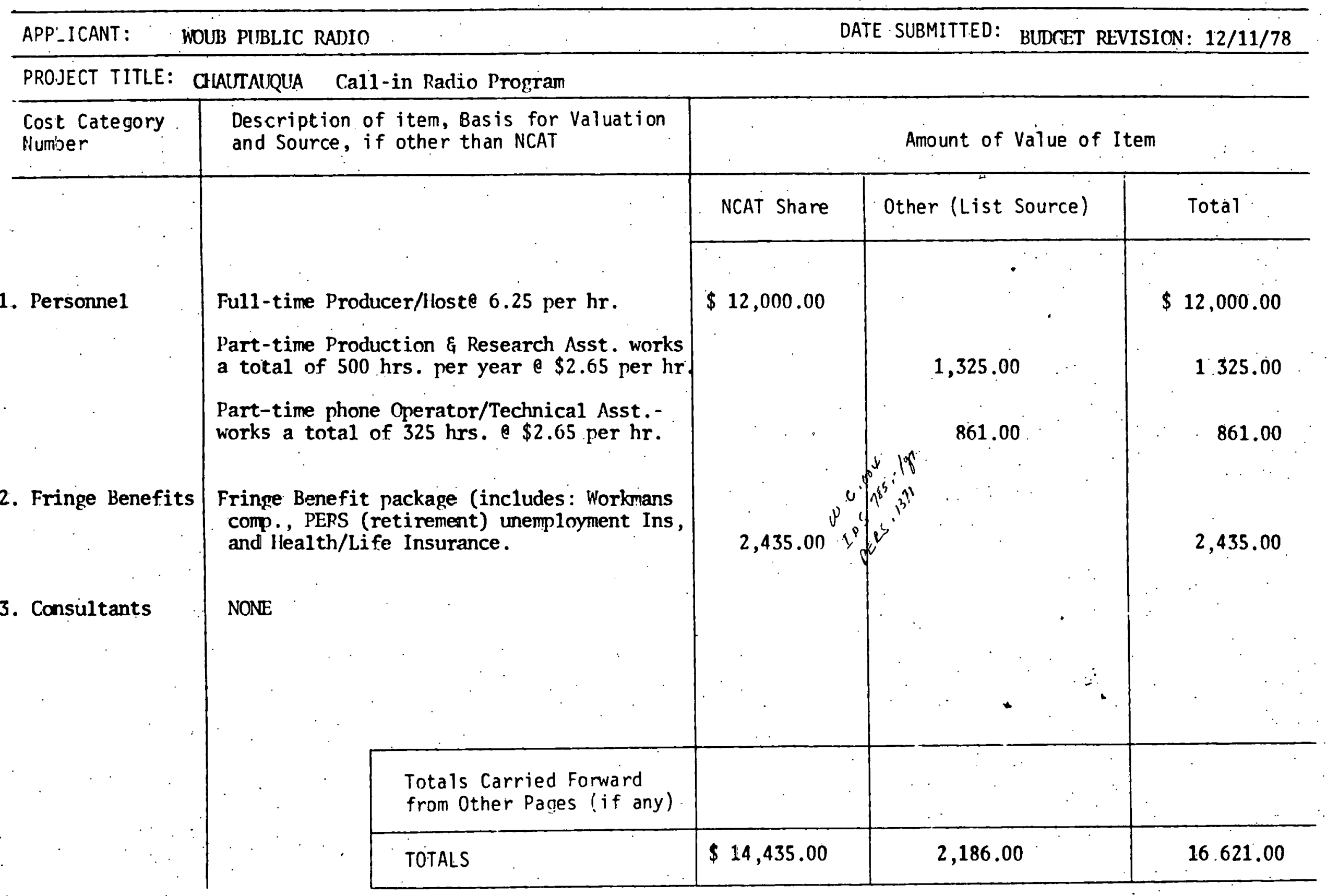


PROJECT TITLE: Chautauqua - Call-in Radio Program

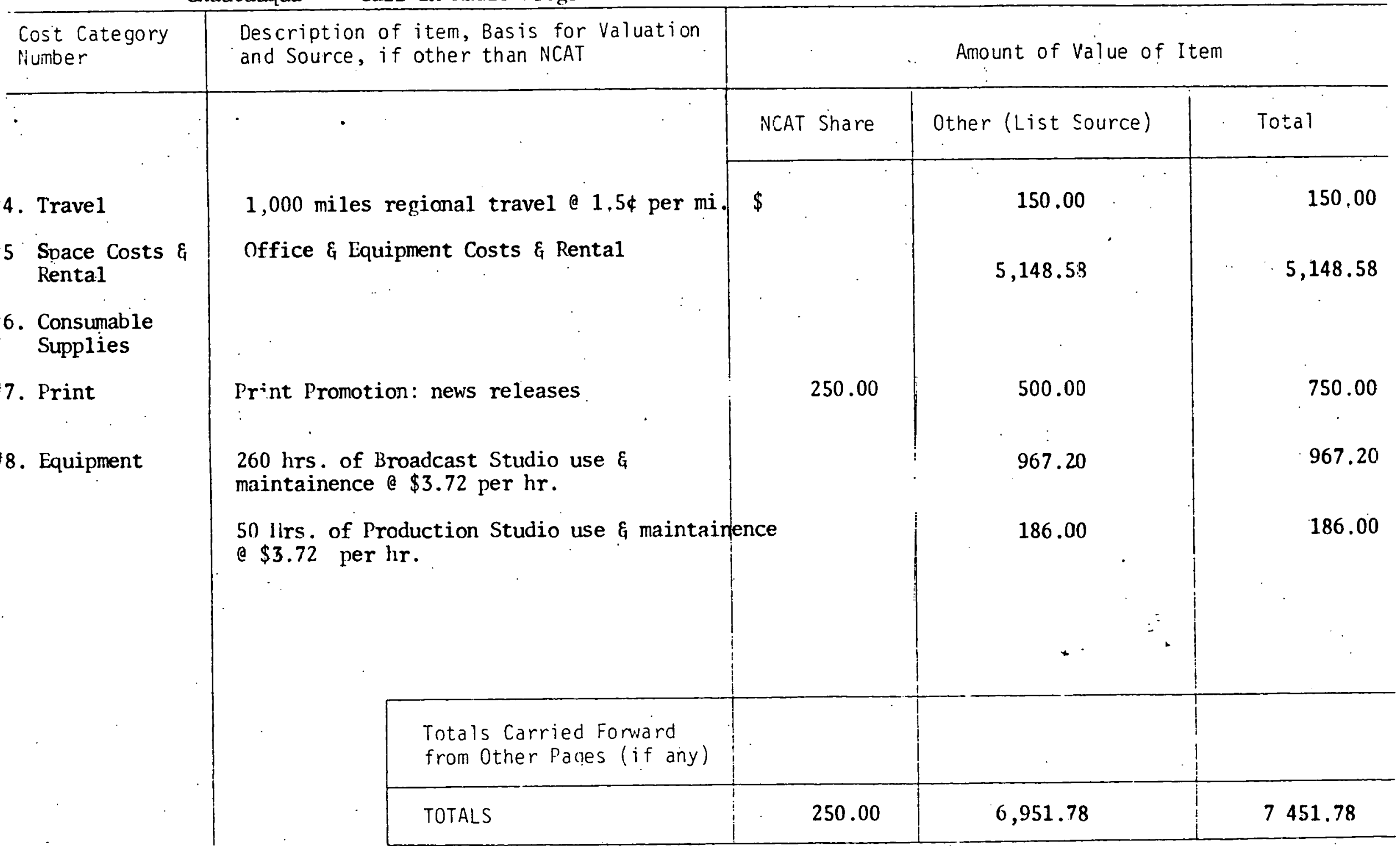


PROJECT TITLE: Chautauqua - Call-in Radio Program

\section{Cost Category Description of item, Bas is for Valuation}

Number

and Source, if other than NCAT

\#9. Purchased parts

\& materials

\#10. Other Direct Costs

\#11. Indirect Costs$$
\text { | }
$$

\section{$260 \mathrm{hrs}$. transmitter time \& $\$ 2.94$ per $\mathrm{hr}$. \\ Audio cassette machine to be used for regional interviews for Chautauqua}

$100 \mathrm{hrs}$. of Audio tape for program production, interviews, and archive purposes

On Air Phone Costs: collect calls from listeners in broadcast region during Chautauqua and an occasional long-distance interview during Chautauqua $\$ 38.49$ per week

indirect personnel costs such as: secretarial administrative \& promotional staff support for this project

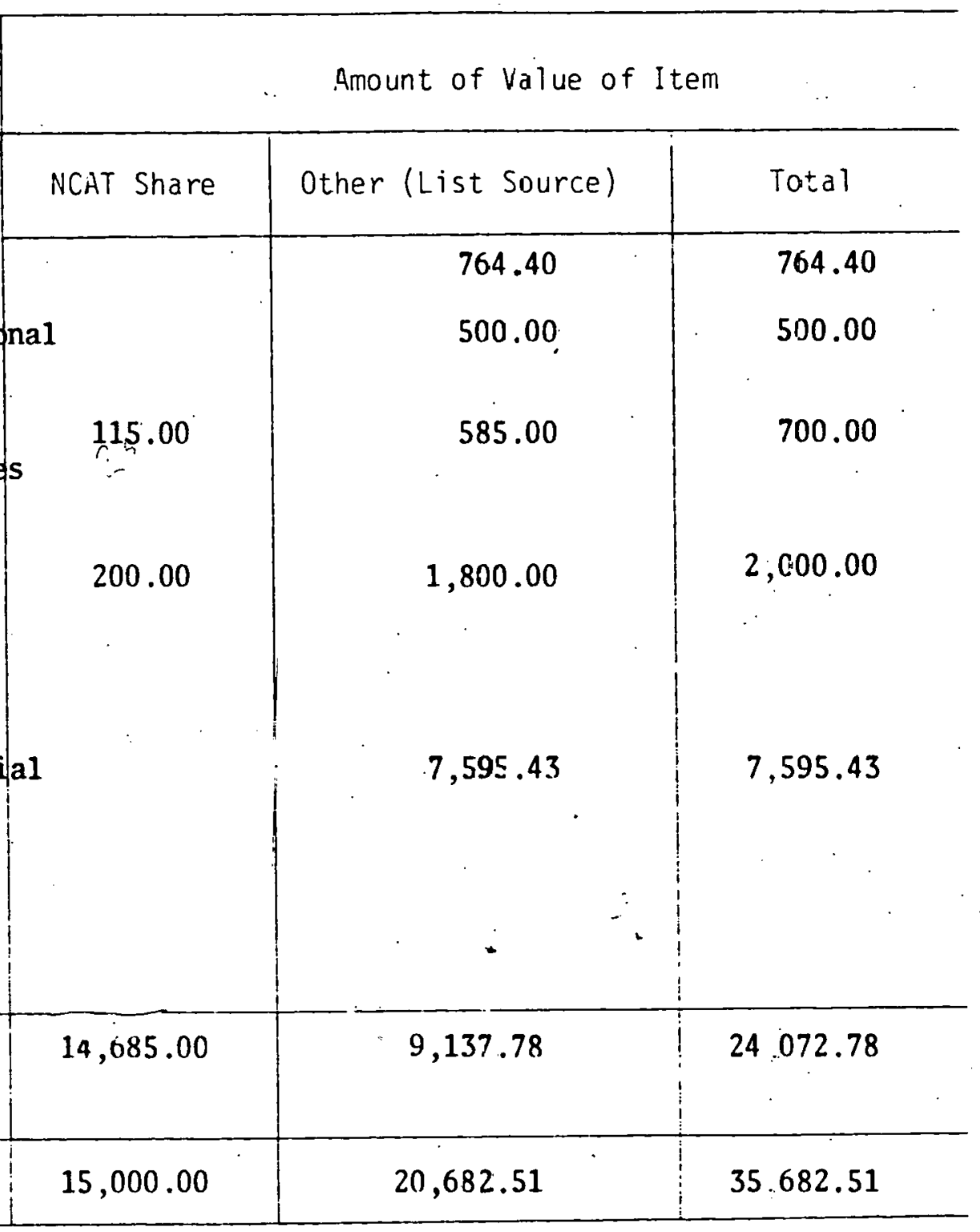


COST ESTIMATE: Dubs of all new Chautauqua Programs (approx. 250)

WOUB Public Radio will provide cassette copies of all the Chautauqua programs for the next year (beginning with NCAT funding). These cassette copies may be used by NCAT for any non-broadcast purpose ; such as archiving information, demonstrations educational purposes etc.

TAPE COST

approximately 250 cassettes $\$ 2.74$ ea.

TOTAL: $\$ 680.00-$

STUDIO/ FACILITIES

A $\$ 1.00$ per hr. fee will be cahrged for use of cassette machine TOTAL: 250.00 to dub Chautauqua programs

TOTAL: $\mathbf{7 2 5 . 0 0}$

$250 \mathrm{hrs}$. of production personel (student) to make cassette recording for NCAT \& $\$ 2.90$ per hr.

TOTAL COST FNR DUBS OF ALL NEH CAHUTAUQUA PROGRAMS (ONE YẼAR) $\ldots \ldots \quad \$ 1,655,00$ 

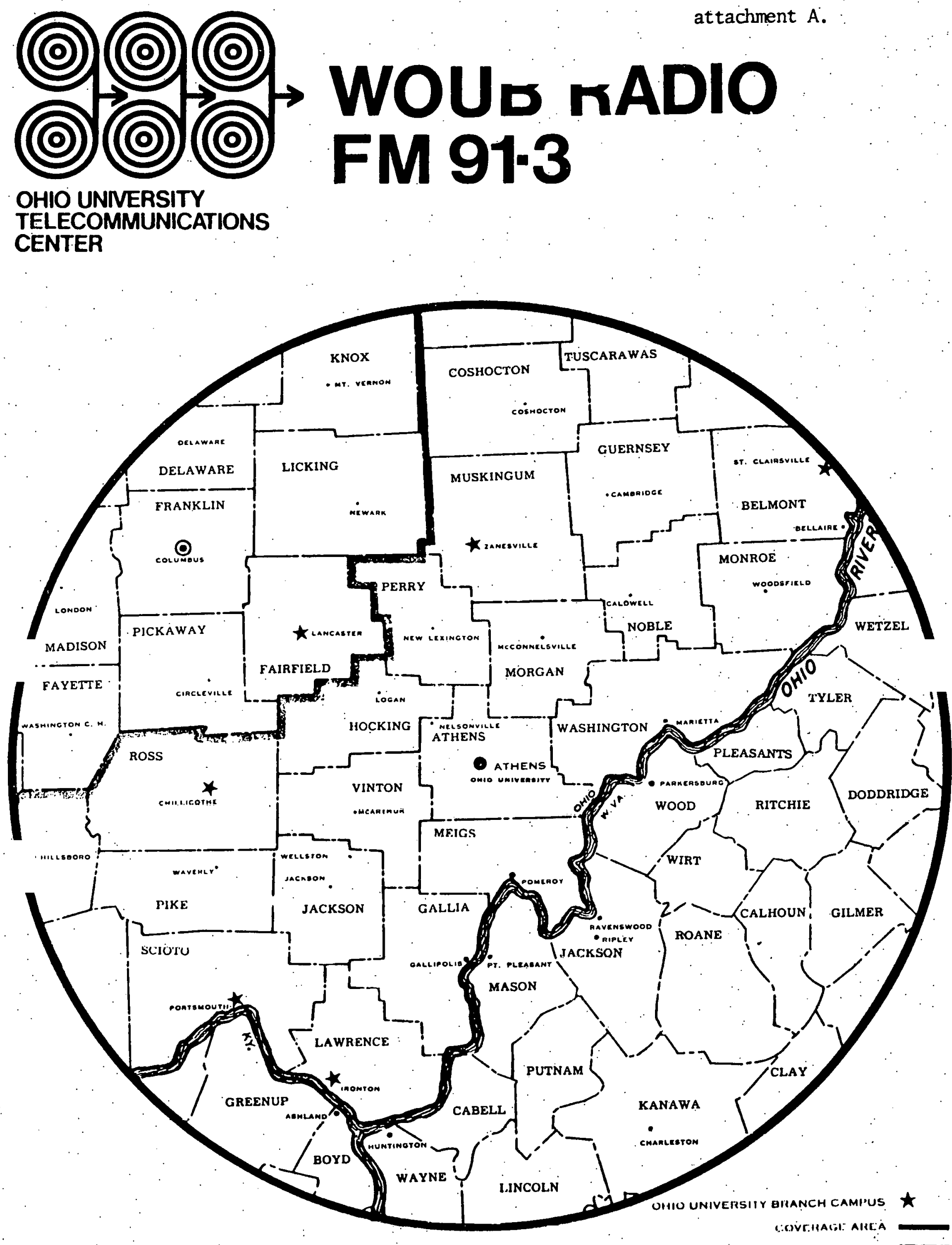


\section{OHIO UNIVERSITY TELECOMMNICATIONS CENTER}

\section{POSITION DESCRIPTION}

PUBLIC RADIO PRODUCER AND HOST

HELD BY: Bobbi Renz

General Guidelines: Responsible for producing/hosting the daily radio call-in talk show Chautauqua for use on WOUB FN consistent with policies set by the Public Radio Program Director.

1. To produce and host the daily radio call-in talk show Shautauqua for broadcast on WOUB FM
1. a. Complies with programming policies and financial considerations as set by Public Radio Program Director

b. Shows initiative, innovation and skill in developing program material

c. Makes optimum use of commumity regional and university resources in program production

d. In proposing program ideas, shows initiative and restraint reflecting financial and operating limitations.

e. Meets programming deadlines for air commi tments

$f$. Meets with production operations and engineering standards

h. Programs are consistent with clearance and copyright restrictions

2. a. Maintain good relations and open communications with regional contacts participation in the development, production and programming of broadcast material (.: ..........

3. Maintain and provide access to programming 3.ä. Files must be kept current, complete files including records of past programs and clear in organization and interviews, as well as listener response and phone participation in $\cdots$ L 


\author{
June 30,1978
}

Ms. Bobbi Renz, Producer of "Chautauqua"

W.O.U.B. Radio

College Street

Athens, Ohio 45701

Dear Ms. Renz:

I am writing to offer you our support in your efforts to secure NCAT (National Center for Appropriate Technology) funds for the expansion of your radio call-in talk show "Chautauqua". Some of my staff have been guests on the show. They feel the topics have been informative and relevant to the needs of low income citizens.

We hope that NCAT offers assistance in bringing these relevant topics to the general attention of nearby communities and especially to the low income community.

Let us know if we can be of further assistance.

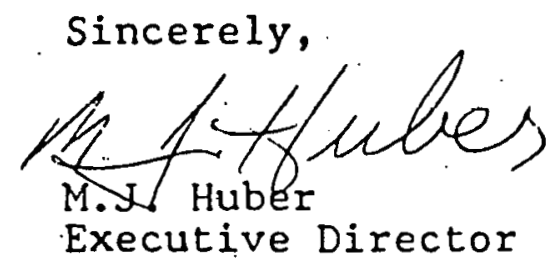

MJH:paf

Executive Director 
GUS R. DOUGLASS

COMMISSIONER

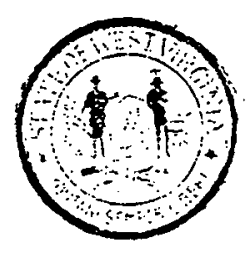

STATE OF WEST VIRGINIA

DEPARTMENT OF AGRICULTURE

ChARLESTON 25305

July 18, 1978

Ms. Bobby Renz

WOUB Radio

Radio and TV

Communications Building

Athens, $\mathrm{OH} \quad 45701$

Dear Ms. Renz:

I was pleasantly surprised and impressed by your recent radio show, Chautauqua. In the course of the years that I have been agriculture commissioner for West Virginia, I have been interviewed on many programs and, generally, they've been talk shows. Your unique approach of providing your listeners with an opportunity to telephone questions was most interesting. I was much impressed by the type of questions, the intelligence in which questions were directed to me, as well as the almost overwhelming volume. In fact, the requests did not cease at the conclusion of the program. The last thing I need in my official duty is an over flow of mail. I was flooded with additional letters directed to me here. I have answered each of these endeavoring to provide an answer or comment upon some questions they had regarding discussions on the programs and other areas of interest to them. Occasionally, I still get a trickle of mail in reference to the program.

I would certainly hope that you can continue this approach and service to your listeners, as you are evidently filling a vacumn and a thirst of information in your listening area. I know that this must be time consuming to prepare and arrange for these programs, but, again, I do feel it commendable, and hopefully a means can be found for its continuation. I have every intention of tuning in your program when the opportunity presents itself that I may get your format from another angle of being a listener rather than a participant. You may rest assured that this department's staff will be happy to assist you as a participant any time in. the future when you feel we can help and the subjects we can discuss will be current.

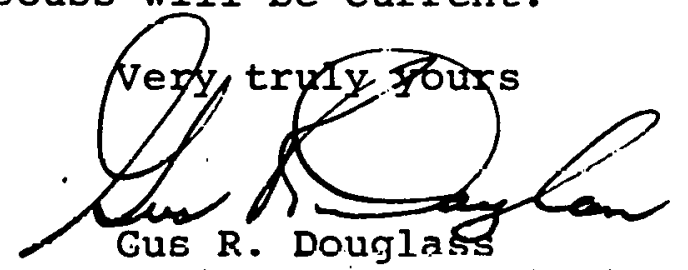

Agriculture Commissioner 
June 27,1978

Bobbi Renz

WOUB Radio

College street

Athens, Ohio

Dear Bobbi,

I am very pleased to have this opportunity to comment on your WOUB radio program, "Chautauqua".

The people I work with and who are your listeners are mostly low income rural families with household. incomes of under $\$ 9,000$. They are interested in self reliance out of necessity. Reducing the cash costs of existence (Food, Housing, clothing, etc.) is a principal endeavor. Burning wood for example, is very popular here. This is not as much because burning wood is currently the chic thing to do, but simply because ready cash outweighs considerations of convenience.

I believe your "Chautauqua" program has served this fundamental need very well and $I$ know it is listened to because my appearances have always resulted in many comments, calls and additional questions from listeners.

As you know, Bobbi, we also have a tremendous interest among young people, wanting to learn the old. ways of providing every day necessities. Our service has probably had to spend more time on home gardening, meat production and slaughtering, and similar homesteading subjects in the past few years than in the previous decade. In these cases, money is not the reason for being interested in Agriculture, farming and country ways. The reason, as I see it, is a need to rediscover one's independence from modern technology and interdependence with our surroundings; to reassure ourselves that we still have and can reproduce the basic skills required for survival. 
For most, this is about a 5 year course of experience where the graduate re-enters the modern world disquised as a lawyer or doctor, blue collar worker or clerk but with, I think, a much. greater confidence in coping with it all.

This concern has also produced a "show me" generation who wants accurate information from knowledgeable and practical people who have done what they teach and can prove it with action.

Your show has concentrated on this approach and in an admirable fashion. Because it touchs on subjects and philosophies which will have an impact on what our world is like in the future, I sincerely hope it can be expanded.

Our Extension Service in Vinton County fully supports your efforts.

Kindest personal regards.

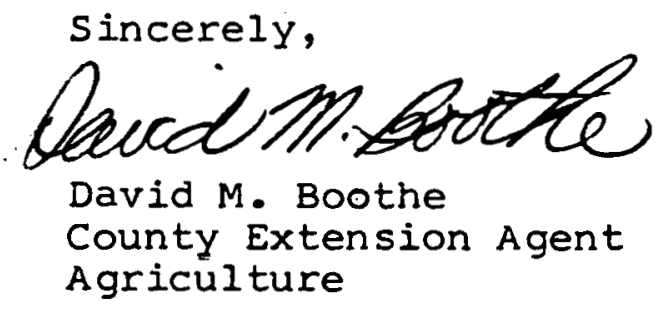

$\mathrm{DMB}: \mathrm{fk}$ 


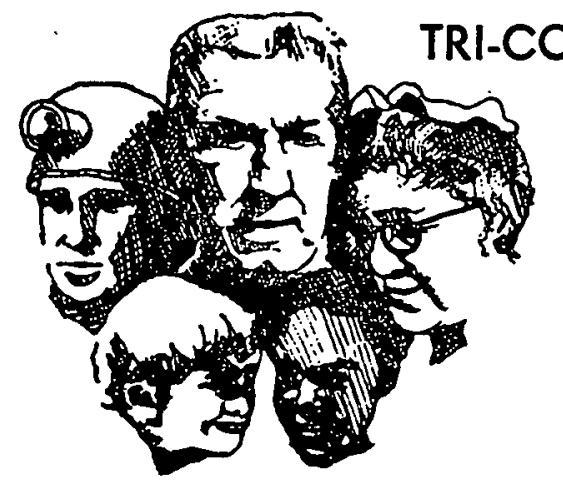

NTY COMMUNITY ACTION AG
Serving Hocking, Athens, and Perry Counties
Route 3, Box 102, Athens, Ohio 45701

(614) $592-6601$

Roger F. Patton Executive Director

August 21, 1978

National Center for Appropriate Technology

P.O. Box 3838

Butte, Montana 59701

Dear Sirs:

On August 17, 1978 the Tri-County Community Action Agency Board of Trustees approved the endorsement of the "Chautauqua" program proposal. The Board felt that this program will offer valuable information to low-income families that will effect the quality of their daily lives.

Again, we wish to express our wholehearted endorsement of this program and our appreciation to NCAT for its consideration in this matter. Thank you.

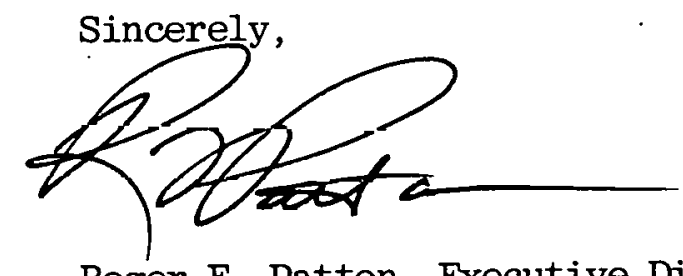

Roger F. Patton, Executive Director TRI-COUNTY COMMUNITY ACTION AGENCY

RFP: pme 
This list reflects the location of some of the call-in participants on Chautauqua during past months. Numerous calls have been received from most of the locations.

\section{COLLECT CALIS}

Albany, Ohio Amesville, Ohio Bätlett, Ohio Bell Valley, Ohio Caldwell, Ohio Chester Hill, Ohio Chillicothe, Ohio Circleville, Ohio Clarksberg, Ohio Columbus, Ohio Coolville, Ohio Corning, Ohio Cottageville, W. Va. Creola, Ohio Cutler, Ohio Gallipolis, Ohio Glouster, Ohio Hamden, Ohio "-risonville, Ohio :ksonville, Ohio

Kentuck, W. Va. Lancaster, Ohio Laurelville, Ohio Lee Township, Oh10 Logan, Ohio Londonderry, Ohio Lower Salem, Ohio Malta, Ohio Marietta, Ohio Mauoun, W. Vá. McArthur, Ohio McConnelsville, Ohio Medina, W. Va. Middleport, Ohio
Mórgan County, w. Va.

Murraysville, W. Va.

Nelsonville, Ohio

Newark, Ohio

New Matamorris, Ohio

Newport, Ohio

Parkersberg, W. Va.

Pennsville, Ohio

Point Pleasant, W. Va.

Portsmouth, Ohio

Radcliffsberg, Ohio

Ravenswood, W. Va.

Reda, W. Va.

Reedsville, Ohio

Ridgeville, Ohio

Rio Grande, Ohio

Ritchie County, W. Va.

Rockport, Ohio

Rutland, Ohio

Sandyville, W. Va.

Sherman, W. Va.

Smithville, W. Va.

South Bloomingville, Ohio

Spencer, W. Va.

Stautsville, Ohio

St. Mary's, W. Va.

Stockworth, Ohio

Vienna, $\mathrm{W} . \mathrm{Va}$.

Waterford, Ohio

Waverly, Ohio

Webster Springs, W. Va.

Wellston, Ohio

Wilkesville, Ohio

Williamsport, Ohio

\section{DIRECT-DIAL CALLS}

Arnoldsberg, W. Va. Athens, Ohio

Belpre, Ohio

Bremen, Ohio

Caananville, Ohio

Chauncey, Ohio

Crooksville, Ohio

Cumberland, Ohio

Elizaboth, W. Va.

Eureka, Ohio

Greensville, Ohio

Guysville, Ohio

Jackson, Ohio

Junction City, Ohio

Lake Hope, Ohio

Meigs County, Ohio

Millfield, Ohio

Millwood, W. Va.

Murray City, Ohio

New England, Ohio

New Marshfield, Ohio

Oak Hill, Ohio

Pomeroy, Ohio

Racine, Ohio

Reno, Ohio

Roseville, Ohio

Shade, Ohio

Sharpsburg, Ohio

Shawnee, Ohio

Stock port, Ohio

Sugar Creek, Ohio

The Plains, Ohio

Union Furnace, Ohio

Vinton County, Ohio

Waterloo Township, Ohio

Williamstown, W. Va.

Zanesville, Ohio 
NOTES: 